Bond University

Research Repository

\title{
Exercise for overweight or obesity
}

Shaw, K; Gennat, H; O'Rourke, P; Del Mar, C

Published in:

Cochrane Database of Systematic Reviews

DOI:

10.1002/14651858.CD003817.pub3

Licence:

Other

Link to output in Bond University research repository.

Recommended citation(APA):

Shaw, K., Gennat, H., O'Rourke, P., \& Del Mar, C. (2006). Exercise for overweight or obesity. Cochrane

Database of Systematic Reviews, (4), 1-112. [CD003817]. https://doi.org/10.1002/14651858.CD003817.pub3

\section{General rights}

Copyright and moral rights for the publications made accessible in the public portal are retained by the authors and/or other copyright owners and it is a condition of accessing publications that users recognise and abide by the legal requirements associated with these rights.

For more information, or if you believe that this document breaches copyright, please contact the Bond University research repository coordinator. 


\title{
Bond University
}

\section{ePublications@bond}

Faculty of Health Sciences \& Medicine Publications

Faculty of Health Sciences \& Medicine

$10-18-2006$

\section{Exercise for overweight or obesity (Review)}

\author{
Kelly A. Shaw \\ University of Tasmania \\ Hani C. Gennat \\ University of Tasmania \\ Peter O'Rourke \\ University of Queensland \\ Chris Del Mar \\ Bond University, chris_del_mar@bond.edu.au
}

Follow this and additional works at: http://epublications.bond.edu.au/hsm_pubs

Part of the Analytical, Diagnostic and Therapeutic Techniques and Equipment Commons

\section{Recommended Citation}

Kelly A. Shaw, Hani C. Gennat, Peter O'Rourke, and Chris Del Mar. (2006) "Exercise for overweight or obesity (Review)" Cochrane Database of Systematic Reviews, (4), Art No. CD003817.

http://epublications.bond.edu.au/hsm_pubs/50 


\section{Exercise for overweight or obesity (Review)}

Shaw K, Gennat H, O'Rourke P, Del Mar C

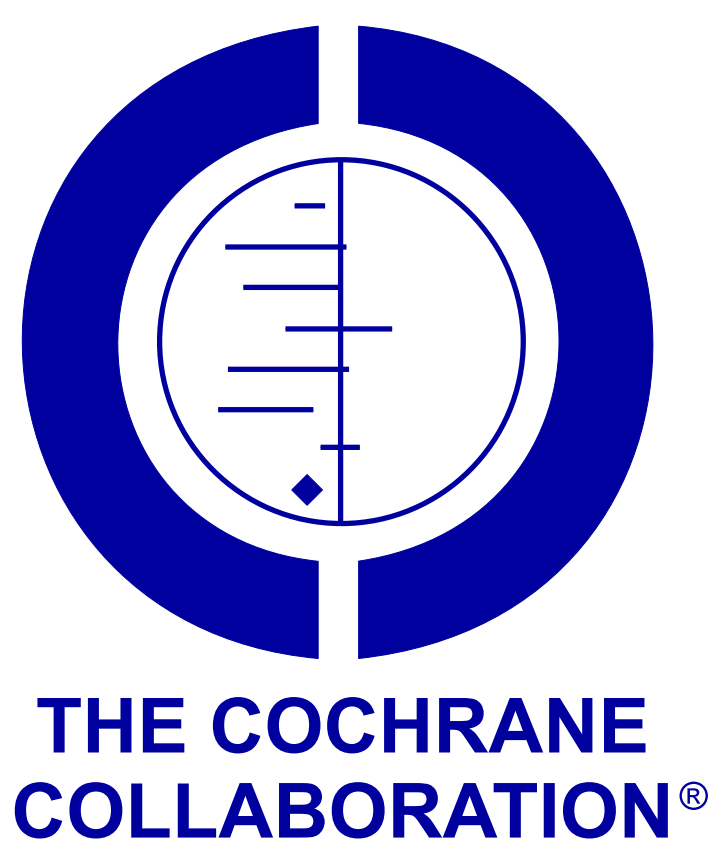

This is a reprint of a Cochrane review, prepared and maintained by The Cochrane Collaboration and published in The Cochrane Library 2007, Issue 2

http://www.thecochranelibrary.com

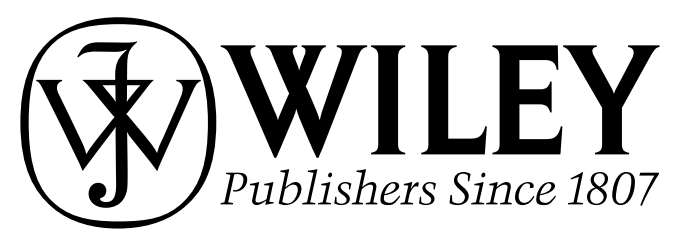

Exercise for overweight or obesity (Review)

Copyright $\odot 2007$ The Cochrane Collaboration. Published by John Wiley \& Sons, Ltd 
TABLE OF CONTENTS

ABSTRACT . . . . . . . . . . . . . . . . . . . . . . . . . . . . . . . . . . . . . . . . . . . . . . . . . . . . . . .

PLAIN LANGUAGE SUMMARY . . . . . . . . . . . . . . . . . . . . . . . . . . . . . . . . . . . . . . .

BACKGROUND . . . . . . . . . . . . . . . . . . . . . . . . . . . . . . . . . . . . . . . . . . . . . .

OBJECTIVES . . . . . . . . . . . . . . . . . . . . . . . . . . . . . . . . . . . . . . . . . . . . . . . . . .

CRITERIA FOR CONSIDERING STUDIES FOR THIS REVIEW . . . . . . . . . . . . . . . . . . . . . . . . . . . .

SEARCH METHODS FOR IDENTIFICATION OF STUDIES . . . . . . . . . . . . . . . . . . . . . . . . . . . . c c c 3

METHODS OF THE REVIEW . . . . . . . . . . . . . . . . . . . . . . . . . . . . . . . . . . . . . 3

DESCRIPTION OF STUDIES . . . . . . . . . . . . . . . . . . . . . . . . . . . . . . . . . . . . . . . . . . . . . .

METHODOLOGICAL QUALITY . . . . . . . . . . . . . . . . . . . . . . . . . . . . . . . . . .

RESULTS . . . . . . . . . . . . . . . . . . . . . . . . . . . . . . . . . . . . . . . . . 6

DISCUSSION . . . . . . . . . . . . . . . . . . . . . . . . . . . . . . . . . . . . . . . . . .

AUTHORS' CONCLUSIONS . . . . . . . . . . . . . . . . . . . . . . . . . . . . . . . . . . . . . . . . . . .

NOTES . . . . . . . . . . . . . . . . . . . . . . . . . . . . . . . . . . . . . . . . . . . . . . . . . 9.9

POTENTIAL CONFLICT OF INTEREST . . . . . . . . . . . . . . . . . . . . . . . . . . . . . . . . . . 9

ACKNOWLEDGEMENTS . . . . . . . . . . . . . . . . . . . . . . . . . . . . . . . . . . . . . . . . . . . . . .

SOURCES OF SUPPORT . . . . . . . . . . . . . . . . . . . . . . . . . . . . . . . . . . . . . . 10

REFERENCES . . . . . . . . . . . . . . . . . . . . . . . . . . . . . . . . . . . . . . . . 10

TABLES . . . . . . . . . . . . . . . . . . . . . . . . . . . . . . . . . . . . . . . . . . 16

Characteristics of included studies . . . . . . . . . . . . . . . . . . . . . . . . . . . . . . . 16

Characteristics of excluded studies . . . . . . . . . . . . . . . . . . . . . . . . . . . . . . . . . . . . .

ADDITIONAL TABLES . . . . . . . . . . . . . . . . . . . . . . . . . . . . . . . . . . . . . . 40

Table 01. Search Strategy . . . . . . . . . . . . . . . . . . . . . . . . . . . . . . . . . . . . 40

Table 02. Original data for all outcomes

Table 03. Summary of Main Findings from Comparisons for Each Outcome . . . . . . . . . . . . . . 60

ANALYSES . . . . . . . . . . . . . . . . . . . . . . . . . . . . . . . . . . . . . . . . . . . . . .

Comparison 01. Exercise versus no treatment control c. . . . . . . . . . . . . . . . . . . . . . . . . 63

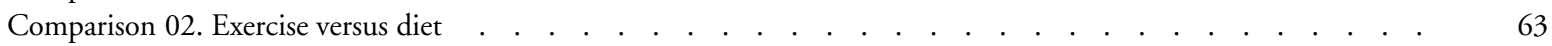

Comparison 03. Exercise + diet versus diet alone . . . . . . . . . . . . . . . . . . . . . . . . . . . . . . . . 63

Comparison 04 . High versus low intensity exercise with dietary change . . . . . . . . . . . . . . . . . . . . 64

Comparison 05. High versus low intensity exercise without dietary change . . . . . . . . . . . . . . . . . 64

INDEX TERMS . . . . . . . . . . . . . . . . . . . . . . . . . . . . . . . . . . . . . . . . 64

COVER SHEET

GRAPHS AND OTHER TABLES . . . . . . . . . . . . . . . . . . . . . . . . . . . . . . . . . . . . . . . . 66

Figure 01. . . . . . . . . . . . . . . . . . . . . . . . . . . . . . . . . . . . . . . . . . . . . . . . . . 66

Analysis 01.01. Comparison 01 Exercise versus no treatment control, Outcome 01 Weight change in kilograms $\quad . \quad$. 67

Analysis 01.02. Comparison 01 Exercise versus no treatment control, Outcome 02 Change in body mass index (BMI) 67

Analysis 01.03. Comparison 01 Exercise versus no treatment control, Outcome 03 Change in systolic blood pressure 67 $(\mathrm{mmHg})$

Analysis 01.04. Comparison 01 Exercise versus no treatment control, Outcome 04 Change in diastolic blood pressure $(\mathrm{mmHg})$

Analysis 01.05. Comparison 01 Exercise versus no treatment control, Outcome 05 Change in total serum cholesterol $(\mathrm{mmol} / \mathrm{l})$

Analysis 01.06. Comparison 01 Exercise versus no treatment control, Outcome 06 Change in serum triglycerides $(\mathrm{mmol} / \mathrm{l})$

Analysis 01.07. Comparison 01 Exercise versus no treatment control, Outcome 07 Change in serum HDL (mmol/l)

Analysis 01.08. Comparison 01 Exercise versus no treatment control, Outcome 08 Change in fasting serum glucose $(\mathrm{mmol} / \mathrm{l})$

Analysis 02.01. Comparison 02 Exercise versus diet, Outcome 01 Weight change in kilograms . . . . . . . . . 70

Analysis 02.02. Comparison 02 Exercise versus diet, Outcome 02 Change in body mass index (BMI) . . . . . . . 71

Analysis 02.03. Comparison 02 Exercise versus diet, Outcome 03 Change in systolic blood pressure $(\mathrm{mmHg}) \quad . \quad$. $\quad 71$

Analysis 02.04. Comparison 02 Exercise versus diet, Outcome 04 Change in diastolic blood pressure $(\mathrm{mmHg}) \quad$. $\quad . \quad 72$

Exercise for overweight or obesity (Review)

Copyright ( 2007 The Cochrane Collaboration. Published by John Wiley \& Sons, Ltd 
Analysis 02.05. Comparison 02 Exercise versus diet, Outcome 05 Change in total serum cholesterol (mmol/l) . . . 72

Analysis 02.06. Comparison 02 Exercise versus diet, Outcome 06 Change in serum triglycerides $(\mathrm{mmol} / \mathrm{l}) \quad$. $\quad . \quad$. $\quad$. 73

Analysis 02.07. Comparison 02 Exercise versus diet, Outcome 07 Change in serum HDL (mmol/l) . . . . . . . 73

Analysis 02.08. Comparison 02 Exercise versus diet, Outcome 08 Change in fasting serum glucose (mmol/l) $\quad . \quad$. $\quad . \quad 74$

Analysis 03.01. Comparison 03 Exercise + diet versus diet alone, Outcome 01 Weight change in kilograms . . . . 74

Analysis 03.02. Comparison 03 Exercise + diet versus diet alone, Outcome 02 Change in body mass index (BMI) $\quad 76$

Analysis 03.03. Comparison 03 Exercise + diet versus diet alone, Outcome 03 Change in systolic blood pressure $(\mathrm{mmHg}) \quad 77$

Analysis 03.04. Comparison 03 Exercise + diet versus diet alone, Outcome 04 Change in diastolic blood pressure 77 $(\mathrm{mmHg})$. . . . . . . . . . . . . . . . . . . . . . . . . . . . . . . . . . . . . . . . . .

Analysis 03.05. Comparison 03 Exercise + diet versus diet alone, Outcome 05 Change in total serum cholesterol (mmol/l) 78

Analysis 03.06. Comparison 03 Exercise + diet versus diet alone, Outcome 06 Change in serum triglycerides (mmol/l) 78

Analysis 03.07. Comparison 03 Exercise + diet versus diet alone, Outcome 07 Change in serum HDL (mmol/l) . . $\quad 79$

Analysis 03.08. Comparison 03 Exercise + diet versus diet alone, Outcome 08 Change in fasting serum glucose (mmol/l) 79

Analysis 04.01. Comparison 04 High versus low intensity exercise with dietary change, Outcome 01 Weight change in 80 kilograms . . . . . . . . . . . . . . . . . . . . . . . . . . . . . . . . . . .

Analysis 04.02. Comparison 04 High versus low intensity exercise with dietary change, Outcome 02 Change in body mass index (BMI)

Analysis 04.03. Comparison $04 \mathrm{High}$ versus low intensity exercise with dietary change, Outcome 03 Change in systolic blood pressure $(\mathrm{mmHg})$

Analysis 04.04. Comparison 04 High versus low intensity exercise with dietary change, Outcome 04 Change in diastolic

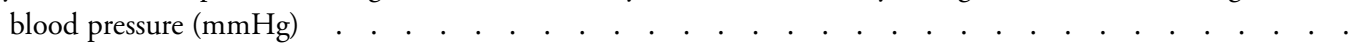

Analysis 04.05. Comparison 04 High versus low intensity exercise with dietary change, Outcome 05 Change in serum cholesterol ( $\mathrm{mmol} / \mathrm{l})$

Analysis 04.06. Comparison 04 High versus low intensity exercise with dietary change, Outcome 06 Change in serum triglycerides $(\mathrm{mmol} / \mathrm{l})$

Analysis 04.07. Comparison 04 High versus low intensity exercise with dietary change, Outcome 07 Change in serum HDL $(\mathrm{mmol} / \mathrm{l})$

Analysis 04.08. Comparison 04 High versus low intensity exercise with dietary change, Outcome 08 Change in serum glucose $(\mathrm{mmol} / \mathrm{l})$.

Analysis 05.01 . Comparison 05 High versus low intensity exercise without dietary change, Outcome 01 Weight change in kilograms

Analysis 05.02 Comparison 05 High versus low intensity exercise without dietary change, Outcome 02 systolic blood pressure $(\mathrm{mmHg})$

Analysis 05.03 . Comparison 05 High versus low intensity exercise without dietary change, Outcome 03 Change in diastolic blood pressure . . . . . . . . . . . . . . . . . . . . . . . . . . . . . .

Analysis 05.04. Comparison 05 High versus low intensity exercise without dietary change, Outcome 04 Change in serum triglycerides $(\mathrm{mmol} / \mathrm{l})$. . . . . . . . . . . . . . . . . . . . . . . . . . . . . . . . . . . . . .

Analysis 05.05. Comparison 05 High versus low intensity exercise without dietary change, Outcome 05 Change in serum $\mathrm{HDL}(\mathrm{mmol} / \mathrm{l})$

Analysis 05.06. Comparison 05 High versus low intensity exercise without dietary change, Outcome 06 Change in serum glucose $(\mathrm{mmol} / \mathrm{l})$. 


\title{
Exercise for overweight or obesity (Review)
}

\author{
Shaw K, Gennat H, O’Rourke P, Del Mar C
}

This record should be cited as:

Shaw K, Gennat H, O’Rourke P, Del Mar C. Exercise for overweight or obesity. Cochrane Database of Systematic Reviews 2006, Issue 4. Art. No.: CD003817. DOI: 10.1002/14651858.CD003817.pub3.

This version first published online: 18 October 2006 in Issue 4, 2006.

Date of most recent substantive amendment: 23 August 2006

\section{A B S T R A C T}

\section{Background}

Clinical trials have shown that exercise in adults with overweight or obesity can reduce bodyweight. There has been no quantitative systematic review of this in The Cochrane Library.

\section{Objectives}

To assess exercise as a means of achieving weight loss in people with overweight or obesity, using randomised controlled clinical trials.

\section{Search strategy}

Studies were obtained from computerised searches of multiple electronic bibliographic databases. The last search was conducted in January 2006.

\section{Selection criteria}

Studies were included if they were randomised controlled trials that examined body weight change using one or more physical activity intervention in adults with overweight or obesity at baseline and loss to follow-up of participants of less than $15 \%$.

Data collection and analysis

Two authors independently assessed trial quality and extracted data.

\section{Main results}

The 43 studies included 3476 participants. Although significant heterogeneity in some of the main effects' analyses limited ability to pool effect sizes across some studies, a number of pooled effect sizes were calculated. When compared with no treatment, exercise resulted in small weight losses across studies. Exercise combined with diet resulted in a greater weight reduction than diet alone (WMD - $1.1 \mathrm{~kg} ; 95 \%$ confidence interval (CI) -1.5 to -0.6). Increasing exercise intensity increased the magnitude of weight loss (WMD $1.5 \mathrm{~kg} ; 95 \%$ CI -2.3 to -0.7). There were significant differences in other outcome measures such as serum lipids, blood pressure and fasting plasma glucose. Exercise as a sole weight loss intervention resulted in significant reductions in diastolic blood pressure (WMD $2 \mathrm{mmHg}$; 95\% CI -4 to -1 ), triglycerides (WMD - $0.2 \mathrm{mmol} / \mathrm{L} ; 95 \% \mathrm{CI}-0.3$ to -0.1 ) and fasting glucose (WMD - $0.2 \mathrm{mmol} / \mathrm{L} ; 95 \%$ CI -0.3 to -0.1 ). Higher intensity exercise resulted in greater reduction in fasting serum glucose than lower intensity exercise (WMD $0.3 \mathrm{mmol} / \mathrm{L} ; 95 \% \mathrm{CI}-0.5$ to -0.2 ). No data were identified on adverse events, quality of life, morbidity, costs or on mortality.

\section{Authors' conclusions}

The results of this review support the use of exercise as a weight loss intervention, particularly when combined with dietary change. Exercise is associated with improved cardiovascular disease risk factors even if no weight is lost.

\section{PLAIN LANGUAGESUMMARY}

Exercise and diet produce weight loss in people with overweight or obesity

Overweight and obesity are important public health problems and are associated with many serious health conditions. The risk of developing overweight and obesity depends on lifestyle factors such as food intake and physical activity levels. Treatment for overweight

Exercise for overweight or obesity (Review)

Copyright ( 2007 The Cochrane Collaboration. Published by John Wiley \& Sons, Ltd 
and obesity therefore commonly involves diet and exercise. We found that exercise has a positive effect on body weight and cardiovascular disease risk factors in people with overweight or obesity, particularly when combined with diet, and that exercise improves health even if no weight is lost. No data were identified on adverse events, quality of life, morbidity, costs or mortality.

\section{B A C K G RO U N D}

\section{Description of the condition}

Overweight and obesity are conditions of excess body fat (NHMRC 1997). The World Health Organisation (WHO) defines weight status according to body mass index (BMI), the ratio of weight (in kilograms) divided by height (in metres squared). A BMI of 20 to 25.9 defines normal weight, 25 to 29.9 defines overweight and equal to or greater than 30 defines obesity (WHO 2003). Overweight and obesity are a major public health problem with more than one billion adults overweight globally, 300 million of which have obesity (WHO 2006). Increased consumption of more energy-dense, nutrient-poor foods with high levels of sugar and saturated fats, combined with reduced physical activity, have led to the increase in prevalence (WHO 2003). Overweight and obesity pose a major risk for serious chronic diseases, including type 2 diabetes, cardiovascular disease, hypertension and stroke, and certain forms of cancer. Effective weight management for individuals and groups with overweight and obesity involves a range of strategies including reducing energy intake through dietary change and increasing energy expenditure by increasing physical activity levels (WHO 2003).

\section{Description of the intervention}

Although evidence supporting the efficacy of exercise to achieve weight loss is disappointing, studies do support the efficacy of exercise to prevent weight gain. A number of large studies, including the Reno diet-heart study, the "First National Health Nutrition and Examination Survey" (NHANES-1) and the Canada Fitness survey have found a negative association between physical activity and weight gain (Foreyt 1995; Williamson 1993; Tremblay 1986; Tremblay 1990). These studies were large-scale cross-sectional and longitudinal studies. The impact of a number of vigorous and nonvigorous leisure activities on weight was examined. People who were habitually more active were found to be less obese. Therefore increasing physical activity, both exercise and habitual activity, may have a role in preventing obesity, preventing worsening of already established obesity, and reducing body mass in obese people.

\section{How the intervention might work}

Even if exercise does not result in weight loss, it confers significant health benefits to people with overweight and obesity. Blood lipid profiles associated with increased risk of coronary heart disease are a common metabolic feature of obesity. Since the early 1980 s there has been increasing evidence that central fat accumulation has an adverse action on lipids, resulting in elevated triglycerides and very-low-density lipoproteins and low levels of high-density lipoproteins (Despres 1994). Exercise, with or without weight loss, improves plasma lipoprotein status, in particular, increasing highdensity lipoproteins therefore may be of particular benefit to people who are abdominally obese even if no weight is lost by exercising. Similarly, large cross-sectional studies demonstrate reduction in blood pressure in those who regularly exercise, compared with sedentary persons, irrespective of weight (Montoye 1972; Sandvik 1993). The large cohort Harvard alumni study, showed that those who engaged in regular vigorous leisure activities had a 33 percent lower risk (relative risk reduction) of developing hypertension and 41 percent reduction (relative risk reduction) in mortality from coronary heart disease over 20 years (Paffenbarger 1983).

Exercise interventions ideally should be used in the context of a multi-component weight loss program to gain their maximum benefit. Diet and exercise combined with psychological interventions comprise an intuitively powerful weight loss program (NHLBI 1998). However, in spite of the increased comprehensiveness of weight loss programs and improvements in patient education, understanding of the role of diet and exercise in weight loss, psychological interventions, and improved pharmacotherapies for weight reduction, results of weight loss trials have continued to remain disappointing (Liao 2000). There are still major gaps in our understanding of the roles of diet, exercise, and psychological therapies in weight reduction. Also, achieving longterm modification of food intake and food type by the obese individual without creating decreases in energy expenditure associated with dieting, and dealing with relapse to pre-intervention diet and exercise behaviours are ongoing challenges (Brownell 1986).

Studies examining the magnitude of weight loss achievable with exercise have shown disappointing results. Garrow and Summerbell, in a meta-analysis of 28 studies of exercise and weight loss, concluded that weight lost in exercise programs without caloric restriction is small and usually ranges from 2 to $7 \mathrm{~kg}$ (Garrow 1995). Ballor and Keesey, in an earlier meta-analysis, also found that weight loss associated with exercise was modest (Ballor 1991). However, considerable research has been performed in the area since these meta-analyses were performed. This review aimed to clarify the effect of exercise on body weight and health in people with overweight and obesity, using high quality criteria to assess and summarise the evidence.

\section{O B JE C T I VES}

To assess the efficacy of exercise as a means of achieving weight loss in people with overweight and obesity. 


\section{CRITERIA FOR CONSIDERING STUDIES FOR THIS REVIEW}

\section{Types of studies}

All randomised controlled clinical trials of exercise in people with overweight or obesity, with a duration of at least three months and loss to follow-up of less than $15 \%$, were considered for inclusion.

\section{Types of participants}

Studies were limited to adult participants (aged over 18 years). Studies included adults with overweight or obesity according to body mass index, waist circumference or waist-to-hip ratio, irrespective of health status.

\section{Types of intervention}

The studies included had an exercise prescription. Exercise is defined as any form of physical activity performed on a repeated basis for an defined period of time (exercise training). Exercise prescriptions include specific recommendations for the type, intensity, frequency and duration of any physical activity with a specific objective (e.g. increase fitness, lose weight) (Bouchard 1994). Studies stating that they simply recommended increasing physical activity were not included within the analyses unless it was possible to quantify the exercise stimulus by some means. Studies that combined exercise and medication associated with weight loss as an intervention were excluded.

\section{Types of outcome measures}

\section{Primary outcomes}

1. Weight or another indicator of body mass (e.g. body mass index, waist measurement, waist-to-hip ratio);

2. Morbidity and mortality;

3. Well-being and quality of life.

\section{Secondary outcomes}

1. Serum lipids;

2. Serum glucose;

3. Systolic and diastolic blood pressure;

4. Adverse effects.

We planned on examining the following effect modifiers if there were sufficient data: sex, age, adherence to treatment, initial weight and co-morbidities.

\section{Timing of outcome assessment}

Studies with a duration including follow-up period of three months or greater were included in this review.

\section{SEARCH METHODS FOR IDENTIFICATIONOF STUDIES}

See: Cochrane Metabolic and Endocrine Disorders Group methods used in reviews.
(1) Electronic databases used included The Cochrane Library, MEDLINE (1966 to 2005), SPORT Discus (1830 to 2005), and EMBASE (1974 to 2005).

(2) Databases of ongoing trials used included Current Controlled Trials (www.controlled-trials.com) and The National Research Register (www.update-software.com/National/nrr-frame.html). (3) The reference lists of review articles and of all included studies were searched in order to find other potentially eligible studies.

(4) Potential missing, unpublished or ongoing studies were planned to be sought by contacting experts in the field. This was not necessary.

(5) Publications in all languages were sought.

Please see under 'Additional tables' for a detailed search strategy (Table 01).

Additional key words of relevance were sought during the electronic or other searches. None were identified.

\section{METHODSOF THEREVIEW}

\section{Selection of studies}

Assessment of quality and results data was undertaken by two reviewers (KS and HCG). Full articles were retrieved for further assessment if the information given in the abstract obtained from the searches suggested that the study: 1. included people who were overweight or obese, 2. compared exercise with placebo or another non-pharmacological weight loss intervention, 3. assessed one or more relevant clinical outcome measures, 4. used random allocation to the comparison groups. When a title or abstract could not be rejected with certainty, the full text of the article was obtained for further evaluation. Interrater agreement for study selection was measured using the kappa statistic (Cohen 1960). Where differences in opinion existed, these were resolved by a third party (POR). Where duplicate publications and companion papers were located, information was maximised by using all versions of the study.

\section{Data extraction and management}

Data extracted included the following:

(1) General information: Published/unpublished, title, authors, source, contact address, country, language of publication, year of publication, duplicate publications.

(2) Trial characteristics: Design, duration, randomisation (and method), allocation concealment (and method), blinding (outcome assessors), check of blinding.

(3) Intervention: Exercise prescription, comparison interventions (method, timing).

(4) Patients: Sampling (random/convenience), exclusion criteria, total number and number in comparison groups, gender, age, diagnostic criteria of overweight or obesity, similarity of groups at baseline, assessment of compliance or relapse, withdrawals or losses to follow-up (reasons or description), subgroups. 
(5) Outcomes: Outcomes specified above, what was the main outcome assessed in the study, other events, length of follow-up. (6) Results: For outcomes and times of assessment, intention-totreat analysis.

A template data extraction form was developed and sent to the Metabolic and Endocrine Disorders Group Editorial Base for approval. Study authors were not contacted for further information.

\section{Assessment of methodological quality of included studies}

The quality of reporting each trial was assessed based largely on the quality criteria specified by Schulz and by Jadad (Schulz 1995; Jadad 1996). In particular, the following factors were studied:

(1) Minimisation of selection bias - a) was the randomisation procedure adequate? $\mathrm{b}$ ) was the allocation concealment adequate?

(2) Minimisation of attrition bias - a) were withdrawals and dropouts completely described? b) was analysis by intention-totreat?

(3) Minimisation of detection bias - were outcome assessors blind to the intervention?

Based on these criteria, studies were subdivided into the following three categories (see Cochrane Handbook):

A - all quality criteria met: low risk of bias.

$\mathrm{B}$ - one or more of the quality criteria only partly met: moderate risk of bias.

$\mathrm{C}$ - one or more criteria not met: high risk of bias.

This classification was planned to be used as the basis of a sensitivity analysis.

Each trial was assessed for quality assessment independently by two reviewers (KS, HCG). Interrater agreement was calculated using the kappa statistic (Cohen 1960).

\section{Data synthesis (meta-analysis)}

Where data were available which were sufficiently similar with respect to interventions and outcomes, pooled estimates of effect were obtained using Review Manager (RevMan) 4.2. Data were entered into RevMan and analysed using RevMan Analyses, the statistical component of RevMan. Fixed-effect models were used to pool data where appropriate.

\section{Assessment of heterogeneity}

Where heterogeneity existed a random effects model was used to explore results. Effect sized are presented as weighted mean differences with $95 \%$ confidence intervals. The chi-square method was used to assess heterogeneity with the significance set at $\mathrm{p}<0.1$. Heterogeneity was also examined with $\mathrm{I}^{2}$. Where $\mathrm{I}^{2}$ values of greater than $50 \%$ were present, meta-analytic pooling was not performed (Higgins 2003).

\section{Subgroup analyses and investigation of heterogeneity}

Should the quantity of data have permitted, we planned to examine subgroups based on the following factors:

(1) Type, intensity and duration of the exercise intervention;
(2) Age;

(3) Gender;

(4) Smoking status;

(5) Different comparison interventions;

(6) Co-morbidities.

\section{Sensitivity analyses}

We compared the results of fixed-and random-effects models. We also planned to perform sensitivity analyses in order to explore the influence of the following factors on effect size:

(1) Repeating the analysis excluding unpublished studies (if there were any);

(2) Repeating the analysis taking account of study quality, as specified above;

(3) Repeating the analysis excluding any very long or large studies to establish how much they dominate the results;

(4) Repeating the analysis excluding studies using the following filters: diagnostic criteria, language of publication, source of funding (industry versus other), country.

Funnel plots were performed for assessment of small study bias.

\section{DESCRIPTIONOFSTUDIES}

\section{Trials identified}

The search strategy, last performed in January 2006, identified 4040 abstracts for perusal. On review of the abstracts, 271 articles were retrieved for perusal. Of these, 89 potentially relevant studies were located.

\section{QUOROM (quality of reporting of meta-analyses) statement} (Moher 1999)

- potentially relevant abstracts identified and screened for retrieval $(\mathrm{n}=4040)$;

- abstracts excluded $(\mathrm{n}=3769)$;

- studies retrieved for more detailed evaluation $(\mathrm{n}=271)$;

- studies excluded $(\mathrm{n}=182)$;

- potentially appropriate studies to be included in the systematic review $(\mathrm{n}=89)$;

- studies excluded from the systematic review, with reasons in 'Table of Excluded Studies' ( $\mathrm{n}=46)$;

- studies included in the systematic review $(n=43)$;

- duplicate publications $(n=2)$;

- RCTs included in the systematic review $(n=41)$.

\section{Excluded studies}

Following an evaluation of the methods and results section of the trials, 46 were excluded from the review. These studies and their reasons for exclusion are presented in the table: 'Characteristics of Excluded Studies'. 


\section{Included studies}

A total of 43 studies, reporting the results from 41 trials, met the inclusion criteria and were included in the review. The kappa statistic for trial selection was $0.73 ; 95 \%$ confidence interval (CI) 0.64 to 0.82 . The details of these studies are described in the table: 'Characteristics of Included Studies'. Two studies were duplicate publications of other studies included in the review. Data from these studies were included and were used to maximise available information about the primary studies (Pritchard 1997; Svendsen 1993). Two studies compared exercise and behaviour therapy with behaviour therapy alone (Jeffery 1998; Jeffery 2003). A number of trials did not present results in a manner that enabled variance data for change in outcome measures to be extracted. These studies, identified in the 'Notes' section of the 'Characteristics of Included Studies' table, are included in the results but are reported narratively (Aggel-Leijssen 2001b; Aggel-Leijssen 2002; Balkestein 1999; Gillett 1987; Manning 1991; Raz 1994; Stensel 1994; Utter 2000; Wing 1988; Wirth 1985). The data from these studies are not included in the analyses.

\section{Studies}

All included trials were randomised controlled clinical trials. Eight trials were factorial in design (Aggel-Leijssen 2001; Anderssen 1996; Cox 2004; Jeffery 1998; Neumark 1995; Nieman 1998; Stefanick 1998; Wood 1991). The remaining 33 were parallel in design.

\section{Participants and settings}

There were a total of 3476 participants in the 41 trials. All trials were conducted in adults. The weighted mean age of participants was 42.4 years for the 32 trials that reported age as a mean value. The remaining nine trials, which reported age as a range, included participants aged between 20 and 75 years. Of the 39 trials that reported gender distribution of participants, 17 included men only, 15 included women only, and 10 included both men and women. The duration of the included studies ranged from 3 to 12 months, including follow-up.

Twenty-four trials were conducted in the United States of America, four were conducted in The Netherlands (Aggel-Leijssen 2001; Aggel-Leijssen 2001b; Aggel-Leijssen 2002; Balkestein 1999), three in Canada (Janssen 2002; Ross 1996; Thong 2000) and Australia (Cox 2004; Cox 1996; Pritchard 1997), two in Israel (Raz 1994; Neumark 1995) and one in Norway (Anderssen 1996), the United Kingdom (Stensel 1994), Denmark (Svendsen 1993) and Germany (Wirth 1985), respectively. All trials were outpatient community studies. None were inpatient hospital studies. The range of outpatient settings in which trials were conducted included general medical clinics, hospital obesity outpatient clinics, primary care, university campuses and workplace settings. Most participants were recruited by local news media (e.g. local newspaper, radio announcements, bulletin boards). One study recruited their participants from a database of participants of a cohort study (Anderssen 1996), one from a group of people newly registered to participate in a concurrent lifestyle intervention trial (Hellenius 1993), one from a database of respondents to a community survey questionnaire (Svendsen 1993), and one from the staff of a national business corporation (Pritchard 1997).

The exercise interventions that were evaluated are listed below. Eighteen trials evaluated multiple exercise interventions within their design, and 23 trials evaluated a single exercise intervention. Twenty-one trials evaluated a walking intervention, 10 evaluated cycle ergometry (exercise bicycle), eight evaluated jogging, eight evaluated weights training, five evaluated commercial aerobics, five evaluated treadmill exercise, two evaluated stair stepping, and one evaluated each of dancing, ball games, calisthenics, rowing, and aqua jogging, respectively. No trials evaluated swimming or water aerobics as weight loss interventions.

Thirteen trials contained groups that compared exercise with no treatment as a weight loss intervention in people with overweight or obesity. Eight trials evaluated walking / jogging, three evaluated cycle ergometry (Aggel-Leijssen 2001b; Cox 2004; Irwin 2003), two evaluated weights training (Irwin 2003; Manning 1991), and one each evaluated aerobics (Pritchard 1997) and ball games / calisthenics (Wirth 1985). The exercise intensity was high (greater than $60 \%$ maximal oxygen uptake (VO2 max) / maximum heart rate) for nine trials, low (less than 60\% VO2 max / maximum heart rate) for one trial (Aggel-Leijssen 2001b), and not specified for two trials (Stensel 1994; Wing 1998). The exercise frequency was greater than five days a week for one trial (Thong 2000) and 3 to 5 days a week for 12 trials. Exercise duration ranged from 15 to 60 minutes with the median exercise duration per session of 45 minutes.

Eleven trials contained groups that compared exercise to diet as weight loss interventions in people with overweight or obesity. Seven trials evaluated walking or jogging, two evaluated aerobic exercise of the participants choice equivalent to brisk walking or jogging (Stefanick 1998; Pritchard 1997), one evaluated cycle ergometry (Cox 2004) and one evaluated aerobic exercise consisting of either walking, jogging, aerobics or circuit training (Anderssen 1996). The exercise intensity was high (greater than $60 \% \mathrm{VO} 2$ max / maximum heart rate) for ten trials and not specified for one trial (Wing 1998). The exercise frequency was greater than five days a week for one trial (Thong 2000), 3 to 5 days a week for nine trials and 2 to 3 days a week for one trial (Hellenius 1993). Exercise duration ranged from 30 to 60 minutes with the median exercise duration per session of 40 minutes. Four studies compared exercise with a low calorie diet (Cox 2004; Schwartz 1987; Schwartz 1990; Thong 2000), three compared exercise with a low fat diet (Stefanick 1998; Anderssen 1996; Pritchard 1997), and four compared exercise with a low fat or low calorie diet (Gordon 1997; Hellenius 1993; Wing 1998; Wood 1988).

Sixteen trials contained groups that compared exercise in combination with diet to diet alone as weight loss interventions in people with overweight or obesity. Seven trials evaluated walking or 
jogging, two evaluated cycle ergometry (Cox 2004; Hays 2004), one evaluated step aerobics (Wadden 1997), one cycling/walking/ stair stepping (Ross 1996), one cycling or walking or aqua jogging (Janssen 2002), one treadmill exercise or cycling or stair stepping (Aggel-Leijssen 2001), one walking in combination with weights training (Whatley 1994), one walking or jogging or aerobics (Neumark 1995), one aerobic exercise in combination with weights training (Svendsen 1993) and one of exercise of the participants choice equivalent to brisk walking or jogging (Stefanick 1998). The exercise intensity was high (greater than 60\% VO2 max / maximum heart rate) for 12 trials, low (lower than 60\% VO2 max / maximum heart rate) for one trial (Janssen 2002) and not specified for three trials (Wing 1998; Wood 1991; Stefanick 1998). The exercise frequency was greater than five days a week for one trial (Neumark 1995) and 3 to 5 days a week for 15 trials. Exercise duration ranged from 30 to 90 minutes with the median exercise duration per session of 50 minutes. A low calorie diet was used for 10 trials, a low fat diet for three trials (Hays 2004; Kiernan 2001; Stefanick 1998) and a low fat or low calorie diet for three trials (Gordon 1997; Wood 1991; Wing 1998).

Eight trials contained groups that compared high with low intensity exercise stimuli as weight loss interventions in people with overweight or obesity. In seven of the eight trials subgroups of participants were also on low fat or low calorie diets. Exercise stimuli investigated included high versus low intensity walking (Jakicic 2003; Leutholtz 1995), step aerobics versus increasing incidental physical activity (Anderson 1999), cycling plus treadmill exercise plus weights training versus cycling plus treadmill exercise alone (Wallace 1997), high versus low intensity walking plus weights training (Whatley 1994), and treadmill exercise plus cycling plus stair stepping versus weights training (Janssen 2002; Ross 1996). The exercise frequency was 3 to 5 days a week for all trials. Exercise duration ranged from 20 to 60 minutes in the high intensity group and 10 to 60 minutes in the low intensity group.

Overall, trials did not differ markedly in the degree of overweight in the patient groups. Most reported weight change as kilograms lost. Only two trials reported weight change as change in BMI alone (Anderssen 1996; Hellenius 1993). Weight entry criteria for most trials included participants with overweight as well as participants with obesity. Twenty-two trials specified weight entry criteria according to BMI (in excess of 25 for all studies except Anderssen 1996 and Irwin 2003 which specified BMI equal or greater than 24 for inclusion). Eight trials specified weight entry criteria according to percentage overweight (all between 110\% to $200 \%$ according to Metropolitan Life Insurance Tables) and five trials according to percentage body fat (all in excess of 24\%). The remainder specified weight entry criteria according to waist-to-hip ratio (Stefanick 1998; Wallace 1997) and kilograms overweight (Anderson 1999; Jeffery 1998;Jeffery 2003).

\section{METHODOLOGICALQUALITY}

The methodological quality of included studies is described in the table 'Characteristics of Included Studies'. All 43 included studies had some methodological weaknesses according to the quality criteria applied. Only four studies (Irwin 2003; Gillett 1987; Stefanick 1998; Wood 1988) reported the method of randomisation. For the remaining studies it was not possible to tell whether allocation to groups was concealed. All included studies had a loss to follow-up of less than $15 \%$ as specified in the inclusion criteria for the review. Blinded outcome assessment was carried out in three studies (Irwin 2003; Anderson 1999; Wing 1988), the others were not clear or not done. The duration of all included studies, including follow-up, was three months or more, as specified in the inclusion criteria for the review. Twenty-five of the 41 trials were four months or less in duration.

Four trials suffered from potential selection bias due to the population from which the sample was selected being biased in some way. Anderssen 1996 recruited the sample from a database of participants of a cohort study, Hellenius 1993 recruited from a group of people newly registered to participate in a concurrent lifestyle intervention trial, the details of which were not specified, Svendsen 1993 recruited from a database of respondents to a community survey questionnaire, the generalizability of which is unknown, and Pritchard 1997 recruited from the staff of a national business corporation, the nature of which is unknown.

Many trials had small sample sizes, meaning that it would have been difficult to detect small but potentially significant differences across groups. Two trials performed intention-to-treat analyses (Irwin 2003; Jakicic 2003). Allocation concealment for all trials was categorised as 'B', indicating that one or more criteria were not met.

\section{RES U L T S}

A summary table 'Summary of main findings from comparisons for each outcome', outlining the changes in outcome measures within each of the comparison groups, is provided in Table 03, original data for all outcomes in Table 02 in the additional tables section.

\section{Primary outcomes}

No data were identified on mortality, morbidity, adverse events or quality of life among the trials included in this review.

\section{Weight}

The effects of interventions on between-group change in weight and body mass index (BMI) are shown in 'Comparisons 01 and 02 '. Due to heterogeneity of interventions and comparisons, we believed it appropriate to obtain pooled estimates for only two groups of trials assessing weight: exercise and diet versus diet alone, and high versus low intensity exercise without dietary change; and 
one group of trials assessing BMI: exercise and diet versus diet alone.

In the group exercise plus diet versus diet alone fourteen trials involving 1049 participants included data regarding weight loss that were suitable for meta-analysis. Participants in both groups lost weight across trials. The pooled effect for interventions with a follow-up between 3 and 12 months was a reduction in weight of $1.1 \mathrm{~kg}(95 \%$ confidence interval (CI), 0.6 to 1.5$)$ in the exercise and diet group compared with the diet alone group. Five trials involving 452 participants included data regarding change in BMI that were suitable for meta-analysis. Participants in both groups reduced BMI. The pooled effect for interventions was a reduction in BMI of $0.4 \mathrm{~kg} / \mathrm{m}^{2}$ (95\% CI, 0.1 to 0.7$)$ in the exercise and diet group compared with the diet alone group.

In the high versus low intensity exercise without dietary change group weight loss data from four trials involving 317 participants were pooled. All trials favoured high intensity exercise for weight loss. The pooled effect for interventions with a follow-up between 3.5 and 12 months was a reduction in weight of $1.5 \mathrm{~kg}(95 \% \mathrm{CI}$, 0.7 to 2.3 ) in the high intensity exercise group compared with the low intensity exercise group.

\section{Secondary outcomes \\ Systolic blood pressure}

Pooled estimates of between-group changes in systolic blood pressure could be estimated for two groups of trials: exercise versus diet and exercise and diet versus diet alone (Comparisons 02.03 and 03.03). Four trials involving 361 participants compared change in systolic blood pressure with exercise versus diet. All trials favoured diet over exercise for reduction in systolic blood pressure. Participants who dieted reduced systolic blood pressure $2 \mathrm{mmHg}(95 \%$ CI, 0.3 to 4 ) more than participants who exercised ( $\mathrm{p}=0.02)$. Six trials involving 615 participants compared change in systolic blood pressure with exercise and diet versus diet alone. Both groups reduced systolic blood pressure and no statistically significant difference between groups was demonstrated $(\mathrm{p}=0.87)$.

\section{Diastolic blood pressure}

Pooled estimates of between-group changes in diastolic blood pressure could be estimated for two groups of trials: exercise versus no treatment, and exercise versus diet (Comparisons 01.04 and 02.04). In the two trials that involved 259 participants and compared change in diastolic blood pressure with exercise versus no treatment, participants who exercised reduced diastolic blood pressure $2 \mathrm{mmHg}(95 \% \mathrm{CI}, 1$ to 4$)$ more than no treatment $(\mathrm{p}=0.01)$. In the four trials that involved 361 participants and compared diet and exercise for reducing diastolic blood pressure, there was no significant difference between interventions $(\mathrm{p}=0.19)$. Both interventions resulted in clinically significant reductions in diastolic blood pressure.

\section{Serum cholesterol}

There was one group of trials where pooled estimates of betweengroup changes in serum cholesterol could be estimated: exercise versus no treatment (Comparison 01.05). Participants who exercised did not reduce their serum cholesterol significantly more than those with no treatment in the three trials, involving 348 participants, that compared the two groups $(\mathrm{p}=0.65)$.

\section{Serum triglycerides}

There were three groups of trials where pooled estimates of between-group changes in triglycerides could be estimated: exercise and diet versus diet alone, high versus low intensity exercise with dietary change, and exercise versus no treatment (Comparisons 01.06, 03.06 and 04.06). No statistically significant difference between interventions was observed for exercise and diet versus diet alone (six trials, 619 participants) $(\mathrm{p}=0.12)$ or high versus low intensity exercise with dietary change (two trials, 65 participants) $(\mathrm{p}=0.98)$. Serum triglycerides were reduced by each intervention and across trials. In the third group of three trials involving 348 participants, people who exercised reduced serum triglycerides by $0.2 \mathrm{mmol} / \mathrm{L}$ ( $95 \% \mathrm{CI}, 0.1$ to 0.3$)$ more than those with no treatment $(\mathrm{p}<0.01)$.

\section{Serum high-density lipoprotein (HDL)}

There was one group of trials where pooled estimates of betweengroup changes in serum HDL were able to be estimated: high versus low intensity exercise with dietary change (Comparison 4.7: Comparisons and Data). Rather than increasing HDL, both high and low intensity exercise were associated with reduced HDL across trials. Low intensity exercise was associated with a greater reduction than high intensity exercise however this difference was not statistically significant (two trials, 65 participants) ( $\mathrm{p}=0.48$ ).

\section{Fasting serum glucose}

There were four groups of trials where pooled estimates of between-group changes in fasting serum glucose could be estimated: exercise and diet versus diet alone, high versus low intensity exercise without dietary change, exercise versus no treatment, and exercise versus diet (Comparisons 01.08, 02.08, 03.08 and 05.06). Exercise reduced fasting serum glucose by $0.2 \mathrm{mmol} / \mathrm{L}$ ( $95 \% \mathrm{CI}$, 0.1 to 0.3 ) compared with no treatment (two trials, 273 participants) ( $\mathrm{p}=0.006)$. High intensity exercise reduced fasting serum glucose by $0.3 \mathrm{mmol} / \mathrm{L}$ ( $95 \% \mathrm{CI}, 0.2$ to 0.5 ) more than low intensity exercise (two trials, 46 participants) $(\mathrm{p}<0.01)$. When diet and exercise were compared, diet resulted in an $0.1 \mathrm{mmol} / \mathrm{L}$ (95\% CI, 0.0 to 0.2 ) greater reduction in fasting serum glucose than exercise (three trials, 354 participants). However, there was no statistically significant difference between diet and exercise versus diet in reducing fasting serum glucose $(\mathrm{p}=0.82)$. Both interventions resulted in reduced fasting serum glucose.

\section{Small study bias}

Publication bias was examined with the use of a funnel plot. The funnel plot for weight change (14 studies) did not suggest the presence of small study bias (Funnel plot). 


\section{Subgroup analyses}

The number of trials available for subgroup analysis was limited for most outcomes except for weight loss in the exercise and diet versus diet only group of trials. The pooled results from this group of trials demonstrated a small but statistically significant effect when the results of a large number of trials were pooled. Subgroup analysis by sex and age could performed. Analysis by sex did no show relevant changes in pooled estimates. Analysis by age demonstrated that the pooled effect for studies with a mean age of participants of less than 45 years was a reduction in weight of $1.6 \mathrm{~kg}$ (95\% CI, 0.6 to 2.6) in the exercise and diet group compared with the diet alone group, and the pooled effect for studies with a mean age of participants of greater than 45 years was a reduction in weight of $1.0 \mathrm{~kg}(95 \% \mathrm{CI}, 1.3$ to 0.7$)$ in the exercise and diet group compared with the diet alone group.

\section{Sensitivity analyses}

Because most trials reported similar components of quality that were assessed (method of randomisation, allocation concealment, and blinding of the assessor), we could not examine the effects of these variables on outcomes.

\section{I S C U S S I O N}

\section{Summary of findings}

The findings of this study demonstrate that exercise has a positive effect on body weight in people with overweight and obesity. Although exercise alone improved weight loss only marginally compared with no treatment in this study, when combined with dietary interventions, the amount of weight loss achieved with exercise increased substantially. These findings are consistent with previous reviews (Miller 1997; McTigue 2003; Douketis 2005) that demonstrate only modest (less than five $\mathrm{kg}$ ) weight loss with exercise alone as a weight loss intervention, and improved weight loss with diet and exercise compared with exercise alone.

An assessment of the effect of exercise intensity on weight loss was an important part of this study. Numerous trials have shown that an inverse association between body weight and physical activity exists (Coakley 1998; DiPietro 1998; King 2001; Swinburn 2004). However, most of these trials have assessed the effect of vigorous activity on body weight. The benefits of moderate and light intensity activity on body weight have been less extensively evaluated (Stewart 1997; Westerterp 2001; Dionne 2003). There is some evidence that moderate exercise such as walking, is no more effective than light exercise, such as calisthenics and stretching, as part of a weight loss programme (Jakicic 1995; Ross 1996). The results of this study support the hypothesis that vigorous activity is more effective than moderate or light intensity exercise in inducing weight loss. In this study high and low intensity exercise were associated with weight loss, both when combined with dietary weight loss methods and when undertaken without dietary change.
However, high intensity exercise was only significantly better than low intensity exercise at inducing weight loss when undertaken without dietary change. When diet was also modified, exercise intensity did not significantly affect the degree of weight loss. It is possible that this occurred because when exercise is combined with diet, the effect of exercise intensity on the magnitude of weight loss is outweighed by the effects of the dietary intervention.

Diet was demonstrated to be significantly more effective at facilitating weight loss than exercise in this meta-analysis. Both low calorie and low fat diets were used as comparison dietary interventions across clinical trials. Each was more effective at facilitating weight loss than exercise alone. This is consistent with the findings of other studies that also demonstrate dietary modification is superior to exercise in attaining weight loss in overweight and obese adults (Curioni 2005; Hansen 2005). It thus appears that dietary interventions are a more potent method for creating an energy imbalance than physical activity interventions.

A strength of this study compared with other systematic reviews and meta-analyses of exercise and weight loss is the inclusion of cardiovascular disease (CVD) risk factors as outcome measures for analyses (Miller 1997; McTigue 2003; Douketis 2005). Positive effects on CVD risk factors were demonstrated with exercise interventions in overweight and obese adults in this study. Those who participated in exercise interventions alone reduced systolic and diastolic blood pressure, cholesterol, triglycerides and fasting serum glucose. They also increased HDL levels. The changes that were statistically significant compared with no treatment were changes in diastolic blood pressure, triglycerides, HDL and glucose.

These changes were independent of significant weight loss. Weight loss does not appear to uniformly improve cardiovascular risk factors, particularly if $5 \%$ or less body weight reduction (Douketis 2005). However, RCTs have demonstrated that exercise improves risk factors for CVD in adult populations (Campbell 1997; Hu 1999; $\mathrm{Hu} 2000$ ). The findings of this study indicate that the benefit of exercise on cardiovascular risk factors extends to adults with overweight and obesity.

Exercise combined with diet also has a positive effect on cardiovascular risk factors. Consistent with previous research, participants in this study who combined exercise with diet reduced systolic and diastolic blood pressure, serum cholesterol and triglycerides, and fasting serum glucose. However, when directly compared, exercise combined with diet was no more effective in reducing the above cardiovascular risk factors than diet alone.

The reason for this finding is uncertain. Both diet and physical activity are known to improve risk factors for CVD in adults (Rossner 2001; Schubert 2006). It was therefore hypothesized that the effects of each on CVD risk would be additive and that a combination of both interventions would have greater efficacy than diet alone. It is possible that participants in the diet only group also increased physical activity levels as a result of study participa- 
tion. Alternatively, the study may have had insufficient power to demonstrate an additive effect. The effect of diet was greater than the effect of exercise on numerous CVD risk factors. Diet may have therefore masked the effect of exercise on CVD risk factors between comparison groups.

Both high and low intensity exercise resulted in reduced systolic blood pressure and serum triglycerides. However, high intensity exercise had a greater positive effect on fasting serum glucose than low intensity exercise, suggesting that exercise intensity affects the magnitude of the health benefit of the exercise undertaken. It has previously been proposed that a threshold of vigorous activity volume exists which has to be reached to affect CVD risk in adults (Cox 2003). Results of this study support this hypothesis and suggest that this threshold may also exist in overweight and obese adults.

\section{Limitations of the review}

A limitation of this systematic review is the paucity of long-term trials available for inclusion in the analyses. Most people lose weight initially and then regain it over time (Egger 1997). Thus, without longer term trials, the true effect of exercise on body weight is difficult to determine. Also, without long-term trials, the effects of exercise on mortality are difficult to determine. The results of this study demonstrated that exercise was associated with improvement in CVD risk factors. However, the effect of exercise on disease endpoints such as myocardial infarction, cerebrovascular accident and type 2 diabetes could not be demonstrated. Without long-term trials it is assumed, but not definite, that exercise will also have positive impacts on these end-points.

Also, a large number of studies were excluded from analysis due to the relatively large losses to follow-up. This was done because if studies with large losses to follow-up were included in the analyses, valid conclusions about the relative efficacy of exercise interventions could not be drawn. Although this is a valid justification to exclude studies with large losses to follow-up, the negative effect of doing so is to reduce the power of meta-analyses.

\section{A U THORS' CONCLUSIONS}

\section{Implications for practice}

This review suggests that exercise is an effective weight loss intervention, particularly when combined with dietary interventions. Exercise is also an effective intervention for improving a range of secondary outcomes even when weight loss does not occur. While this review did not show any long-term morbidity and mortality benefits associated with exercise, exercise was shown to positively impact the intermediate outcomes that are commonly associated with cardiovascular disease.

\section{Implications for research}

A large amount of research has been undertaken to assess the effects of exercise on weight loss in people who are overweight or obese. Exercise stimuli that have been studied include walking, jogging, weights training, stationary cycling, aerobics, ball games, calisthenics and stair stepping. Further studies could assess alternative exercise stimuli such as increased incidental physical activity and water based activities. Every effort should be made to maintain high retention rates in trials, and reasons for withdrawal should be ascertained so that factors affecting exercise adherence can be further explored. Studies with longer duration of follow-up would provide further information regarding the long-term health effects of regular physical activity in people who are overweight or obese.

\section{NOT E S}

\section{CHANGES TO PUBLISHED PROTOCOL}

OBJECTIVE: Changed from 'regular physical activity' to 'exercise'; add 'overweight' to 'obesity'

TYPES OF STUDIES: Add 'loss to follow-up of less than 15\%'; delete 'quasi-randomised trials'

TYPES OF OUTCOME MEASURES: Delete from additional outcome measures 'VO2max' and 'cost'; delete 'relapse'; timing of outcome assessment changed to 'duration including follow-up of three months or more were included'

METHODS OF THE REVIEW: Change second reviewer from CDM to HCG for quality assessment of trials, data extraction, data entry; change third reviewer from FT to POR for resolving differences of opinion

DATA ANALYSIS: Dichotomous data not identified therefore relative risk omitted; heterogeneity explored using I-squared in addition to chi-squared

\section{POTENTIAL CONFLICTOF INTEREST}

None known.

\section{ACKNOWLEDGEMENTS}

The authors gratefully acknowledge the contribution of Ms Fiona Tito from the Cochrane Consumer Review Group for her invaluable assistance in preparation of the protocol of this review. We also wish to acknowledge the assistance of Dr Sandi Pirozzo and Professor Paul Glasziou in providing advice regarding analysis of results. 


\section{SOURCES OF SUPPORT}

\section{External sources of support}

- National Health and Medical Research Council AUSTRALIA

Internal sources of support

- Royal Australian College of General Practitioners AUSTRALIA

\section{R E F E R E NCE S}

\section{References to studies included in this review}

Aggel-Leijssen 2001 \{published data only\} van Aggel-Leijssen D, Saris W, Hul G, van Baak M. Short-term effects of weight loss with or without low-intensity exercise training on fat metabolism in obese men. American Journal of Clinical Nutrition 2001;73:523-531.

Aggel-Leijssen 2001b \{published data only\} van Aggel-Leijssen D, Saris W, Wagenmakers A, Jul G, van Baak M. The effect of low-intensity exercise training on fat metabolism of obese women. Obesity Research 2001;9(2):86-96.

Aggel-Leijssen 2002 \{published data only\} Aggel-Leijssen D, Saris W, Wagenmakers A, Senden J, Van Baak M. Effect of exercise training at different intensities on fat metabolism of obese men. Journal of Applied Physiology 2002;92:1300-1309.

Anderson 1999 \{published data only\} Anderson R, Wadden T, Bartlett S, Zemel B, et al. Effects of lifestyle activity vs structured aerobic exercise in obese women: A randomized trial. Journal of the American Medical Association 1999;281(4):335340 .

Anderssen 1996 \{published data only\}

Anderssen S, Hjermann I, Urdal P, Torjesen P, Holme I. Improved carbohydrate metabolism after physical training and dietary intervention in individuals with the 'atherothrombogenic syndrome'. Oslo Diet and Exercise Study (ODES). A randomized trial. Journal of Internal Medicine 1996;240:203-209.

Balkestein 1999 \{published data only\}

Balkestein E, van Aggel-Leijssen D, van Baak M, Struijker-Boudier $\mathrm{H}$, van Bortel $\mathrm{L}$. The effect of weight loss with or without exercise training on large artery compliance in health obese men. Journal of Hypertension 1999;17:1831-1835.

Cox 1996 \{published data only\}

Cox K, Puddey I, Morton A, Burke V, Beilin L, McAleer M. Exercise and weight control in sedentary overweight men: effects on clinic and ambulatory blood pressure. Journal of Hypertension 1996;14:779790 .

Cox 2004 \{published data only\}

Cox K, Burke V, Morton A, Beilin L, Puddey I. Independent and additive effects of energy restriction and exercise on glucose and insulin concentrations in sedentary overweight men. American Journal of Clinical Nutrition 2004;80:308-316.
Gillett 1987 \{published data only\}

Gillett P, Eisenman P. The effect of intensity controlled aerobic dance exercise on aerobic capacity of middle-aged, overweight women. Research in Nursing and Health 1987;10:383-390.

Gordon 1997 \{published data only\}

Gordon N, Scott C, Levine B. Comparison of single versus multiple lifestyle interventions: are the antihypertensive effects of exercise training and diet-induced weight loss additive?. American Journal of Cardiology 1997;79:763-767.

Hays 2004 \{published data only\} Hays N, Starling R, Liu X, Sullivan D, Trappe T, Fluckey J, Evans W. Effects of an ad libitum low-fat, high-carbohydrate diet on body weight, body composition, and fat distribution in older men and women. Archives of Internal Medicine 2004;164:210-217.

Hellenius 1993 \{published data only\}

Hellenius M, Faire U, Berglund B, Hamsten A, Krakau I. Diet and exercise are equally effective in reducing risk for cardiovascular disease. Results of a randomized controlled study in men with slightly to moderately raised cardiovascular risk factors. Atherosclerosis 1993; 103:81-91.

Irwin 2003 \{published data only\} Irwin M, Yasui Y, Ulrich C, Bowen D, Rudolph R, Schwartz R, Yukawa M, Aiello E, Potter J, McTiernan A. Effect of exercise on total and intra-abdominal body fat in postmenopausal women: a randomized controlled trial. Journal of the American Medical Association 2003;289(3):323-330.

Jakicic 1995 \{published data only\} Jakicic J, Wing R, Butler B, Robertson R. Prescribing exercise in multiple short bouts versus one continuous bout: effects on adherence, cardiorespiratory fitness, and weight loss in overweight women. International Journal of Obesity 1995;19:893-901.

Jakicic 2003 \{published data only\} Jakicic J, Marcus B, Gallagher K, Napolitano M, Lang W. Effect of exercise duration and intensity on weight loss in overweight, sedentary women: a randomized trial. Journal of the American Medical Association 2003;290(10):1323-1330.

Janssen 2002 \{published data only\} Janssen I, Fortier A, Hudson R, Ross R. Effects of an energy-restrictive diet with or without exercise on abdominal fat, intermuscular fat, and metabolic risk factors in obese women. Diabetes Care 2002;25 (3):431-438. 
Jeffery 1998 \{published data only\}

Jeffery R, Thorson C, Wing R, Burton L. Use of personal trainers and financial incentives to increase exercise in a behavioral weightloss program. Journal of Consulting and Clinical Psychology 1998;66 (5):777-783.

Jeffery 2003 \{published data only\} Jeffery R, Wing R, Sherwood N, Tate D. Physical activity and weight loss: does prescribing higher physical activity goals improve outcome?. American Journal of Clinical Nutrition 2003;78:684-689.

Kiernan 2001 \{published data only\}

Kiernan M, King A, Stefanick M, Killen J. Men gain additional psychological benefits by adding exercise to a weight loss program. Obesity Research 2001;9(12):770-777.

Leutholtz 1995 \{published data only\}

Leutholtz B, Keyser R, Heusner W, Wendt V, Rosen L. Exercise training and severe caloric restriction: Effect on lean body mass in the obese. Archives of Physical Medicine and Rehabilitation 1995;76: 65-70.

Manning 1991 \{published data only\} Manning J, Dooly-Manning C, White K, Kampa I, Silas S, Kesselhaut M, Ruoff M. Effects of a resistive training program on lipoprotein-lipid levels in obese women. Medicine and Science in Sports and Exercise 1991;23(11):1222-1226.

Neumark 1995 \{published data only\}

Neumark-Sztainer D, Kaufmann N, Berry E. Physical activity within a community-based weight control program: Program evaluation and predictors of success. Public Health Reviews 1995;23:237-251.

Nieman 1998 \{published data only\}

Nieman D, Nehlsen-Cannarella S, Henson D, Koch A, Butterworth D, Fagoaga O, Utter A. Immune response to exercise training and / or energy restriction in obese women. Medicine and Science in Sports and Exercise 1998;30(5):679-686.

Pritchard 1997 \{published data only\}

* Pritchard J, Nowson C, Wark J. A worksite program for overweight middle-aged men achieves lesser weight loss with exercise than with dietary change. Journal of the American Dietetic Association 1997;97 (1):37-42.

Pritchard J, Nowson C, Wark J. Bone loss accompanying diet-induced or exercise-induced weight loss: a randomised controlled study. International Journal of Obesity 1996;20:513-520.

Raz 1994 \{published data only\}

Raz I, Hauser E, Bursztyn M. Moderate exercise improves glucose metabolism in uncontrolled elderly patients with non-insulin-dependent diabetes mellitus. Israel Journal of Medical Science 1994;30:766770 .

Ross 1996 \{published data only\} Ross R, Rissanen J, Pedwell H, Clifford J, Shragge P. Influence of diet and exercise on skeletal muscle and visceral adipose tissue in men. Journal of Applied Physiology 1996;81(6):2445-2455.

Schwartz 1987 \{published data only\}

Schwartz R. The independent effects of dietary weight loss and aerobic training on high density lipoproteins and apolipoprotein A-I concentrations in obese men. Metabolism 1987;36(2):165-171.
Schwartz 1990 \{published data only\}

Schwartz R, Jaeger L, Veith R, Lakshminarayan S. The effect of diet or exercise on plasma norepinephrine kinetics in moderately obese young men. International Journal of Obesity 1990;14:1-11.

Stefanick 1998 \{published data only\}

Stefanick M, Mackey S, Sheehan M, Ellsworth N, Haskell W, Wood P. Effects of diet and exercise in men and postmenopausal women with low levels of HDL cholesterol and high levels of LDL cholesterol. The New England Journal of Medicine 1998;339(1):12-20.

Stensel 1994 \{published data only\} Stensel D, Brooke-Wavell K, Hardman A, Jones P, Norgan N. The influence of a 1-year programme of brisk walking on endurance fitness and body composition in previously sedentary men aged 42-59 years. European Journal of Applied Physiology 1994;68:531-537.

Svendsen 1993 \{published data only\}

* Svendsen O, Hassager C, Christiansen C. Effect of an energyrestrictive diet, with or without exercise, on lean tissue mass, resting metabolic rate, cardiovascular risk factors, and bone in overweight postmenopausal women. The American Journal of Medicine 1993;95: $131-140$.

Svendsen O, Krotkiewski M, Hassager C, Christiansen C. Effects on muscles of dieting with or without exercise in overweight postmenopausal women. Journal of Applied Physiology 1996;80:13651370.

Thong 2000 \{published data only\}

Thong F, Hudson R, Ross R, Janssen I, Graham T. Plasma leptin in moderately obese men: independent effects of weight loss and aerobic exercise. American Journal of Physiology, Endocrinology and Metabolism 2000;279:307-313.

Utter 2000 \{published data only\}

Utter A, Whitcomb D, Nieman D, Butterworth D, Vermillion S. Effects of exercise training on gallbladder function in an obese female population. Medicine and Science in Sports and Exercise 2000;32(1): 41-49.

Wadden 1997 \{published data only\}

Wadden T, Vogt R, Andersen R, Bartlett S, Foster G, Wilk J, Kuehnel R, Weinstock R, Buckenmeyer P, Berkowitz R, Steen S. Exercise in the treatment of obesity: effects of four interventions on body composition, resting energy expenditure, appetite and mood. Journal of Consulting and Clinical Psychology 1997;65(2):269-277.

Wallace 1997 \{published data only\}

Wallace M, Mills B, Browning C. Effects of cross-training on markers of insulin resistance / hyperinsulinemia. Medicine and Science in Sports and Exercise 1997;29(9):1170-1175.

Whatley 1994 \{published data only\}

Whatley J, Gillespie W, Honig J, Walsh M, Blackburn A, Blackburn G. Does the amount of endurance exercise in combination with weight training and a very-low-energy diet affect resting metabolic rate and body composition?. American Journal of Clinical Nutrition 1994;59:1088-1092.

Wing 1988 \{published data only\}

Wing R, Epstein L, Paternostro-Bayles M, Kriska A, Nowalk M, Gooding W. Exercise in a behavioural weight control programme for obese patients with Type 2 (non-insulin-dependent) diabetes. Diabetologia 1988;31:902-909. 
Wing 1998 \{published data only\}

Wing R, Venditti E, Jakicic J, Polley B, Lang W. Lifestyle intervention in overweight individuals with a family history of diabetes. Diabetes Care 1998;21(3):350-360.

Wirth 1985 \{published data only\} Wirth A, Diehm C, Hanel W, Welte J, Vogel I. Training-induced changes in serum lipids, fat tolerance, and adipose tissue metabolism in patients with hypertriglyceridemia. Atherosclerosis 1985;54:263271.

Wood 1988 \{published data only\}

Wood P, Stefanick M, Dreon D, Frey-Hewitt B, Garay S, Williams P, Superko R, Fortmann S, Albers J, Vranizan K, Ellsworth N, Terry R, Haskell W. Changes in plasma lipids and lipoproteins in overweight men during weight loss through dieting as compared with exercise. The New England Journal of Medicine 1988;319(18):1173-1179.

Wood 1991 \{published data only\}

Wood P, Stefanick M, Williams P, Haskell W. The effects on plasma lipoproteins of a prudent weight-reducing diet, with or without exercise, in overweight men and women. The New England Journal of Medicine 1991;325(7):461-466.

\section{References to studies excluded from this review Ades 2003}

Ades P, Savage P, Cress E, Brochu M, Lee M, Poehlman E. Resistance training on physical performance in disables older female cardiac patients. Medicine and Science in Sports and Exercise 2003;35(8):12651270.

Aiello 2004

Aiello E, Yutaka Y, Tworoger S, Ulrich C, Irwin M, Bowen D, Schwartz R, Kumai C, Potter J, McTiernan A. Effect of a year long, moderate-intensity exercise intervention on the occurrence and severity of menopause symptoms in postmenopausal women. Menopause 2004;11(4):382-388.

Aldred 1995

Aldred H, Hardman A, Taylor S. Influence of 12 weeks of training by brisk walking on postprandial lipemia and insulinemia in sedentary middle-aged women. Metabolism 1995;44(3):390-397.

\section{Asikainen 2002}

Asikainen T, Miilunpalo S, Oja P, Rinne M, Pasanen M, Vuori I. Walking trials in postmenopausal women: effect of one vs two daily bouts on aerobic fitness. Scandinavian Journal of Medicine and Science in Sports.

\section{Blumenthal 2000}

Blumenthal J, Sherwood A, Gullette E, Babyak M, Waugh R, Georgiades $\mathrm{A}$, Craighead $\mathrm{L}$, et al. Exercise and weight loss reduce blood pressure in men and women with mild hypertension. Archives of Internal Medicine 2000;160:1947-1958.

\section{Cox 2003}

Cox K, Burke V, Morton A, Beilin L, Puddey I. The independent and combined effects of 16 weeks of vigorous exercise and energy restriction on men - a randomized controlled trial. Metabolism 2003; 52(1):107-115.

Cuff 2003

Cuff D, Meneilly G, Martin A, Ignaszewski A, Tildesley H, Frohlich $\mathrm{J}$. Effective exercise modality to reduce insulin resistance in women with type 2 diabetes. Diabetes Care 2003;26(11):2977-2982.

\section{Donnelly 2003}

Donnelly J, Kirk E, Jacobsen D, Hill J, Sullivan D, Johnson S. Effects of 16 months of verified, supervised aerobic exercise on macronutrient intake in overweight men and women: the Midwest Exercise Trial. American Journal of Clinical Nutrition 2003;78:950-956.

\section{Dunn 1999}

Dunn A, Marcus B, Kampert J, Garcia M, et al. Comparison of lifestyle and structured interventions to increase physical activity and cardiorespiratory fitness: a randomized trial. Journal of the American Medical Association 1999;281:327-334

\section{Dzator 2004}

Dzator J, Hendrie D, Burke V, Gianguilio N, Gillam H, Beilin L, Houghton S. A randomized trial of interactive group sessions achieved greater improvements in nutrition and physical activity at a tiny increase in cost. Journal of Clinical Epidemiology 2004;57:610 619.

Esposito 2003

* Esposito K, Pontillo A, Di Palo C, Giugliano G, Masella M, Marfella R, Giugliano D. Effect of weight loss and lifestyle changes on vascular inflammatory markers in obese women. Journal of the American Medical Association 2003;289(14):1799-1804.

Esposito 2004

Esposito K, Giugliano F, DiPalo C, Giugliano G, Marfella R, D'Andrea F, D'Armiento M, Giugliano D. Effect of lifestyle changes on erectile dysfunction in obese men: A randomized controlled trial. Journal of the American Medical Association 2004;291(24):29782984.

\section{Figueroa 2003}

Figueroa A, Going S, Milliken L, Blew R, Sharp S, Teixeira P, Lohman T. Effects of exercise training and hormone replacement therapy on lean and fat mass in postmenopausal women. The Journals of Gerontology 2003;58A(3):266-270.

\section{Fogelholm 2001}

Fogelholm G, Sievanen H, Kukkonen-Harjula T, Pasanen M. Bone mineral density during reduction, maintenance and regain of body weight in premenopausal, obese women. Osteoporosis International 2001;12:199-206.

\section{Grant 2004}

Grant S, Todd K, Aitchison T, Kelly P, Stoddart D. The effects of a 12week group exercise programme on physiological and psychological variables and function in overweight women. Public Health 2004; 118:31-42.

\section{Hartwell 1986}

Hartwell S, Kaplan R, Wallace J. Comparison of behavioral interventions for control of type II diabetes mellitus. Behavior Therapy 1986; 17:447-461.

\section{Hinderliter 2002}

Hinderliter A, Sherwood A, Gullette E, Babyak M, et al. Reduction of left ventricular hypertrophy after exercise and weight loss in overweight patients with mild hypertension. Archives of Internal Medicine 2002;162(12):1333-1340.

\section{Houmard 2003}

Houmard J, Tanner C, Slentz C, Duscha B, McCartney J, Kraus W. Effect of the volume and intensity of exercise training on insulin sensitivity. Journal of Applied Physiology 2004;96:101-106. 


\section{Huttunen 1979}

Huttunen J, Lansimies E, Voutilainen E, Ehnholm C, Hietanen E, Penttila I, et al. Effect of moderate physical exercise on serum lipoproteins. Circulation 1979;60(6):1220-1229.

\section{Jakicic 1998}

Jakicic J, Polley B, Wing R. Accuracy of self-reported exercise and the relationship with weight loss in overweight women. Medicine and Science in Sports and Exercise 1998;30(4):634-638.

\section{Kirk 2003}

Kirk E, Jacobsen D, Gibson C, Hill J, Donnelly J. Time course for changes in aerobic capacity and body composition in overweight men and women in response to long-term exercise: the Midwest Exercise Trial. International Journal of Obesity 2003;27:912-919.

\section{Kraemer 1997}

Kraemer W, Volek J, Clark K, Gordon S, Incledon T, Puhl S, et al. Physiological adaptations to a weight-loss dietary regimen and exercise programs in women. Journal of Applied Physiology 1997;83: 270-279.

\section{Kraemer 1999}

Kraemer W, Jeff V, Clark K, Scott G, Puhl S, Koziris P, et al. Influence of exercise training on physiological and performance changes with weight loss in men. Medicine and Science in Sports and Exercise 1999; 31(9):1320-1329.

\section{Lehmann 1995}

Lehmann R, Vokac A, Miedermann K, Agosti K, Spinas G. Loss of abdominal fat and improvement of the cardiovascular risk profile by regular moderate exercise training in patients with NIDDM. Diabetologia 1995;38:1313-1319.

Lejeune 2003

Lejeune M, van Aggel-Leijssen D, van Baak M, Westerterp-Plantenga M. Effects of dietary restraint vs exercise during weight maintenance in obese men. European Journal of Clinical Nutrition 2003;57:13381344.

\section{Levesque 1997}

Levesque M, Boulay M, Bouchard C, Simoneau J. Time course of training-induced changes in maximal exercise of short duration in men and women. International Journal of Sports Medicine 1997;18: 464-469.

\section{Lindstrom 2003}

Lindstrom J, Louheranta A, Mannelin M, Rastas M, Salminen V, Eriksson J, Uusitupa M, Tuomilehto J. The Finnish diabetes prevention study: Lifestyle intervention and 3-year results on diet and physical activity. Diabetes Care 2003;26(12):3230-3236.

\section{Loreto 2003}

Loreto C, Fanelli C, Lucidi P, Murdolo G, de Cicco A, Parlanti N, Santeusanio F, Brunetti P, de Feo P. Validation of a counseling stategy to promote the adoption and the maintenance of physical activity by type 2 diabetic subjects. Diabetes Care 2003;26(2):404-408.

\section{Mensink 2003}

Mensink M, Blaak E, Corpeleijn E, Saris W, deBruin T, Feskens E. Lifestyle intervention according to general recommendations improves glucose tolerance. Obesity Research 2003;11(12):1588-1596.

\section{Messier 2000}

Messier S, Loeser R, Mitchell M, Valle G, Morgan T, Rejeski W, et al. Exercise and weight loss in obese older adults with knee osteoarthritis: a preliminary study. Journal of the American Geriatric Society 2000; 48:1062-1072.

\section{Nicklas 2004}

Nicklas B, Ambrosius W, Messier S, Miller G, Penninx B, Loeser R, Palla S, Bleecker E, Pahor M. Diet-induced weight loss, exercise and chronic inflammation in older, obese adults: a randomized controlled clinical trial. American Journal of Clinical Nutrition 2004;79:544551.

\section{Okura 2003}

Okura T, Nakata Y, Tanaka K. Effects of exercise intensity on physical fitness and risk factors for coronary heart disease. Obesity Research 2003;11(9):1131-1139.

\section{Potteiger 2003}

Potteiger J, Jacobsen D, Donnelly J, Hill J. Glucose and insulin responses following 16 months of exercise training in overweight adults: The Midwest Exercise Trial. Metabolism 2003;52(9):1175-1181.

\section{Probart 1991}

Probart C, Notelovitz M, Martin D, Khan F, Fields C. The effect of moderate aerobic exercise on physical fitness among women 70 years and older. Maturitas 1991;14:49-56.

\section{Proper 2003}

Proper K, Hildebrandt V, Ban der Beek A, Twisk J, Van Mechelen W. Effect of individual counseling on physical activity fitness and health: A randomized controlled trial in a workplace setting. American Journal of Preventive Medicine 2003;24(3):218-226.

\section{Racette 1995}

Racette S, Schoeller D, Kushner R, Neil K, Herling-Iaffaldano K. Effects of aerobic exercise and dietary carbohydrate on energy expenditure and body composition during weight reduction in obese women. American Journal of Clinical Nutrition 1995;61:486-494.

\section{Ribeiro 1984}

Ribeiro G, Hartley H, Sherwood J, Herd J. The effectiveness of a low lipid diet and exercise in the management of coronary artery disease. American Heart Journal 1984;108(5).

\section{Samaras 1997}

Samaras K, Ashwell S, Mackintosh A, Fleury A, Campbell L, Chisholm D. Will older sedentary people with non-insulin-dependent diabetes mellitus start exercising? A health promotion model. Diabetes Research and Clinical Practice 1997;37:121-128.

\section{Schmitz 2003}

Schmitz K, Jensen M, Kugler K, Jeffery R, Leon A. Strength training for obesity prevention in midlife women. International Journal of Obesity 2003;27:326-333.

\section{Schuler 1991}

Schuler G, Hambrecht R, Schlierf G, Niebauer J, Hauer K, Neumann J, et al. Regular physical exercise and low-fat diet. Circulation 1991; 86(1):1-11.

\section{Slentz 2004}

Slentz C, Duscha B, Johnson J, Ketchum K, Aiken L, Samsa G, Houmard J, Bales C, Kraus W. Effects of the amount of exercise on body weight, body composition and measures of central obesity. Archives of Internal Medicine 2004;164(1):31-39.

\section{Stahle 2000}

Stahle A, Lindquist I, Mattsson E. Important factors for physical activity among elderly patients one year after an acute myocardial 
infarction. Scandanavian Journal of Rehabilitation Medicine 2000;32: 111-116.

\section{Teixeira 2003}

Teixeira P, Going S, Houtkooper L, Metcalfe L, Blew R, Flint-Wagner H, Cussler E, Sardinha L, Lohman T. Resistance training in postmenopausal women with and without hormone therapy. Medicine and Science in Sports and Exercise 2003;35(4):555-562.

\section{Watkins 2003}

Watkins L, Sherwood A, Feinglos M, Hinderliter A, Babyak M, Gullette E, Waugh R, Blumenthal J. Effects of exercise and weight loss on cardiac risk factors associated with syndrome X. Archives of Internal Medicine 2003;163(16):1889-1895.

\section{Weinstock 1998}

Weinstock R, Dai H, Wadden T. Diet and exercise in the treatment of obesity: effects of 3 interventions on insulin resistance. Archives of Internal Medicine 1998;158(22):2477-2485.

\section{Yamanouchi 1995}

Yamanouchi K, Shinozaki T, Chikada K, Nishikawa T, Ito K, Shimizu $S$, et al. Daily walking combined with diet therapy is a useful means for obese NIDDM patients not only to reduce body weight but also to improve insulin sensitivity. Diabetes Care 1995;18(6):775-778.

\section{Additional references}

\section{Ballor 1991}

Ballor D, Keesey R. A meta-analysis of the factors affecting exerciseinduced changes in body mass, fat mass and fat-free mass in males and females. International Journal of Obesity 1991;15:717-26.

\section{Bouchard 1994}

Bouchard C, Shephard RJ, Stephens TE. Physical activity fitness, and health: international proceedings and consensus statement. Champaign, Ill, Human Kinetics Publishers, 1994.

\section{Brownell 1986}

Brownell K, Marlatt G, Lichtenstein E, Wilson G. Understanding and preventing relapse. American Psychologist 1986;41(7):765-82.

\section{Campbell 1997}

Campbell A, Robertson M, Gardner M, Norton R, Tilyard M, Buchner D. Randomised controlled trial of a general practice programme of home-based exercise to prevent falls in elderly women. BMJ 1997; 315:1065-9.

\section{Coakley 1998}

Coakley E, Kawachi I, Manson J, Speizer F, Willet W, Colditz G. Lower levels of physical functioning are associated with higher body weight among middle-aged and older women. International Journal of Obesity and Related Metabolic Disorders 1998;22:958-65.

\section{Cohen 1960}

Cohen J. A coefficient of agreement for nominal scales. Educational and Psychological Measurement 1960;20:37-46.

\section{Cox 2003}

Cox K, Burke V, Morton A, Beilin L, Puddey I. The independent and combined effects of 16 weeks of vigorous exercise and energy restriction on body mass and composition in free-living overweight men--a randomized controlled trial. Metabolism: clinical and experimental 2003;52:107-15.

\section{Curioni 2005}

Curioni C, Lourenco P. Long-term weight loss after diet and exercise: a systematic review. International Journal of Obesity 2005;29:116874.

\section{Despres 1994}

Despres J. Dyslipidaemia and obesity. Ballieres Clinical Endocrinology and Metabolism 1994;8:629-36.

\section{Dionne 2003}

Dionne I, Ades P, Poehlman E. Impact of cardiovascular fitness and physical activity level on health outcomes in older persons. Mechanisms of Ageing and Development 2003;124:259-67.

\section{DiPietro 1998}

DiPietro L, Kohl H, Barlow C, Blair S. Improvements in cardiorespiratory fitness attenuate age-related weight gain in healthy men and women: The Aerobics Center Longitudinal Study. International Journal of Obesity 1998;22:55-62.

\section{Douketis 2005}

Douketis J, Macie C, Thabane L, Williamson D. Systematic review of long-term weight loss studies in obese adults: clinical significance and applicability to clinical practice. International Journal of Obesity 2005;29:1153-67.

\section{Egger 1997}

Egger G, Swinburne B. An "ecological" approach to the obesity pandemic. BMJ 1997;315(7106):477-80

\section{Foreyt 1995}

Foreyt J, Brunner R, Goodrich G, St Jeor S, Miller G. Psychological correlates of reported physical activity in normal-weight and obese adults: the Reno diet-heart study. International Journal of Obesity and Related Metabolic Disorders 1995;19 (suppl 4):S69-72.

\section{Garrow 1995}

Garrow J, Summerbell C. Meta-analysis: effect of exercise, with or without dieting, on the body composition of overweight subjects. European Journal of Clinical Nutrition 1995;49:1-10.

\section{Hansen 2005}

Hansen K, Shriver T, Schoeller D. The effects of exercise on the storage and oxidation of dietary fat. Sports Medicine 2005;35:36373.

\section{Higgins 2003}

Higgins J, Thompson S, Deeks J, Altman D. Measuring inconsistency in meta-analysis. BMJ 2003;327:556-60.

\section{Hu 1999}

Hu F, Sigal R, Rich-Edwards J. Walking compared with vigorous physical activity and risk of type 2 diabetes in women. JAMA 1999; 182:1433-39.

\section{Hu 2000}

Hu F, Stampfer M, Colditz G. Physical activity and risk of stroke in women. JAMA 2000;283:2961-7.

\section{Jadad 1996}

Jadad A, Moore A, Carroll D, Jenkinson C, Reynolds DJM, Gavaghan DJ, et al. Assessing the quality of reports of randomized clinical trials: is blinding necessary?. Controlled Clinical Trials 1996;17: $1-12$.

\section{King 2001}

King G, Fitzhugh E, Basset D, McLaughlin J, Strath S, Swartz A. Relationship of leisure-time physical activity and occupational activity 
to the prevalence of obesity. International Journal of Obesity 2001;25: $606-12$.

Liao 2000

Liao K. Cognitive-behavioural approaches and weight management: an overview. Journal of the Royal Society of Health 2000;120(1):2730.

\section{McTigue 2003}

McTigue K, Harris R, Hemphill B, Lux L, Sutton S, Bunton A. Screening and interventions for obesity in adults: summary of the evidence for the US preventive services taskforce. Annals of Internal Medicine 2003;139:933-49.

\section{Miller 1997}

Miller W, Koceja D, Hamilton E. A meta-analysis of the past 25 years of weight loss research using diet, exercise or diet plus exercise intervention. International Journal of Obesity and Related Metabolic Disorders 1997;21:941-7.

\section{Moher 1999}

Moher D, Cook DJ, Eastwood S, Olkin I, Rennie D, Stroup DF. Improving the quality of reports of meta-analyses of randomised controlled trials: the QUOROM statement. Quality of Reporting of Meta-analyses. Lancet 1999;354(9193):1896-900.

\section{Montoye 1972}

Montoye H, Metzner H, Keller J, Johnson B, Epstein F. Habitual physical activity and blood pressure. Medicine Science Sports and Exercise 1972;4:175-81.

\section{NHLBI 1998}

National Heart Lung and Blood Institute. Clinical guidelines on the identification, evaluation, and treatment of overweight and obesity in adults: The evidence report. National Institute of Health, 1998.

\section{NHMRC 1997}

National Health and Medical Research Council. Acting on Australia's weight: a strategic plan for the prevention of overweight and obesity. Springfield: Australian Government Publishing Services, 1997.

\section{Paffenbarger 1983}

Paffenbarger R, Wing A, Hyde R, Jung D. Physical activity and incidence of hypertension in college alumni. American Journal of Epidemiology 1983;117:245-57.

\section{Rossner 2001}

Rossner S. Obesity in the elderly - a future matter of concern?. Obesity Reviews 2001;2:183-188.

\section{Sandvik 1993}

Sandvik L, Erikssen J, Thaulow E, Erikssen G, Mundal R, Rodahl K. Physical fitness as a predictor of mortality among healthy middle aged Norwegian men. New England Journal of Medicine 1993;328: $533-7$.

\section{Schubert 2006}

Schubert C, Rogers N, Remsberg K, Sun S, Chumlea W, Demerath E. Lipids, lipoproteins, lifestyle, adiposity and fat-free mass during middle age: the Fels Longitudinal Study. International Journal of Obesity 2006;30:251-60.

\section{Schulz 1995}

Schultz KF, Chalmers I, Hayes RJ, Altman DG. Empirical evidence of bias: dimensions of methodological quality associated with estimates of treatment effects in controlled trials. JAMA 1995;273:408-12.

\section{Stewart 1997}

Stewart A, Hays R. Conceptual, measurement, and analytical issues in assessing health status of older populations. In: HickeyT, SpeersM, ProhaskaT editor(s). Public Health and Aging. Baltimore: Johns Hopkins University Press, 1997:163-89.

\section{Swinburn 2004}

Swinburn B, Caterson I, Seidell J, James W. Diet, nutrition and the prevention of excess weight gain and obesity. Public Health Nutrition 2004;7:123-246.

\section{Tremblay 1986}

Tremblay A, Fontaine E, Poehlman E. The effect of exercise-training on resting metabolic rate in lean and moderately obese individuals. International Journal of Obestiy 1986;10:511-7.

\section{Tremblay 1990}

Tremblay A, Despres J, Leblanc C, et al. Effect of intensity of physical activity on body fatness and fat distribution. American Journal of Clinical Nutrition 1990;51:153-7.

\section{Westerterp 2001}

Westerterp K, Meijer E. Physical activity and parameters of aging: a physiological perspective. Journals of Gerontology 2001;56:7-12.

\section{WHO 2003}

WHO. Report of a Joint WHO/FAO Expert Consultation Report of a Joint WHO/FAO Expert Consultation Joint WHO / FAO Expert Report on Diet, Nutrition and the Prevention of Chronic Disease. Diet, Nutrition and the Prevention of Chronic Disease. Geneva: World Health Organization, 2003.

\section{WHO 2006}

World Health Organisation. Obesity and Overweight. Global Strategy on Diet, Physical Activity and Health. http://www.who.int/dietphysicalactivity/publications/facts/obesity/en/ 2006.

\section{Williamson 1993}

Williamson D, Madans J, Anda R, Kleinman J, Kahn H, Byers T. Recreational physical activity and ten-year weight change in a US national cohort. International Journal of Obesity and Related Metabolic Disorders 1993;17:279-86.

*Indicates the major publication for the study 
T A B LE S

\section{Characteristics of included studies}

\begin{tabular}{|c|c|}
\hline Study & Aggel-Leijssen 2001 \\
\hline Methods & $\begin{array}{l}\text { DESIGN: Factorial; Randomisation method not stated } \\
\text { BLINDING: } \\
\text { patients - not stated } \\
\text { caregivers - not stated } \\
\text { outcome assessors - not stated } \\
\text { DURATION OF INTERVENTION: } 12 \text { weeks } \\
\text { DROPOUTS: } 7.5 \% \\
\text { Analysis by treatment received }\end{array}$ \\
\hline Participants & $\begin{array}{l}\text { COUNTRY: Netherlands } \\
\text { n: } 40 \\
\text { AGE: N=38.9 years } \\
\text { MALES=all } \\
\text { WEIGHT ENTRY CRITERIA: BMI }>27 \\
\text { EXCLUSION CRITERIA: }>2 \text { hrs a week spent in sports activities, subjects with physically demanding jobs }\end{array}$ \\
\hline Interventions & $\begin{array}{l}\text { INTERVENTION } 1(\mathrm{n}=17) \text { : modifast very low calorie diet for } 6 \text { weeks then low calorie diet } \\
\text { INTERVENTION } 2(\mathrm{n}=20) \text { : modifast for } 6 \text { weeks then low calorie diet + exercise (cycle ergometer, walking } \\
\text { or aqua jogging) } 4 \text { times a week for } 60 \text { minutes a session at } 40 \% \text { VO } 2 \text { max intensity } \\
\text { FOLLOW-UP: } 12 \text { weeks }\end{array}$ \\
\hline Outcomes & $\begin{array}{l}\text { BODY MEASURES: weight loss }(\mathrm{kg}) \text {, BMI, body density } \\
\text { OTHER: VO2 max, physical activity questionnaire }\end{array}$ \\
\hline \multicolumn{2}{|l|}{ Notes } \\
\hline Allocation concealment & B - Unclear \\
\hline
\end{tabular}

\begin{tabular}{|c|c|}
\hline Study & Aggel-Leijssen 2001b \\
\hline Methods & $\begin{array}{l}\text { DESIGN: Parallel; Randomisation method not stated } \\
\text { BLINDING: } \\
\text { patients - not stated } \\
\text { caregivers - not stated } \\
\text { outcome assessors - not stated } \\
\text { DURATION OF INTERVENTION: } 12 \text { weeks } \\
\text { DROPOUTS: none } \\
\text { Analysis by treatment received }\end{array}$ \\
\hline Participants & $\begin{array}{l}\text { COUNTRY: Netherlands } \\
\text { n: } 13 \\
\text { AGE: N=40.7 years } \\
\text { MALES=none } \\
\text { WEIGHT ENTRY CRITERIA: BMI > } 29 \\
\text { EXCLUSION CRITERIA: abnormal menstrual cycle, poor health as assessed by medical history and physical } \\
\text { examination, }>3 \text { kg weight change in the previous } 2 \text { months, taking medication known to affect the variables } \\
\text { measured, }<2 \text { hours a week in sports activities, physically demanding employment }\end{array}$ \\
\hline Interventions & $\begin{array}{l}\text { INTERVENTION } 1(\mathrm{n}=7) \text { : cycle ergometry } 3 \text { days a week for } 57 \text { minutes at } 40 \% \text { VO2max } \\
\text { INTERVENTION } 2(\mathrm{n}=6) \text { : no exercise FOLLOW-UP: } 12 \text { weeks }\end{array}$ \\
\hline
\end{tabular}




\section{Characteristics of included studies (Continued)}

Outcomes BODY MEASURES: weight loss $(\mathrm{kg})$, hydrostatic weighing, WHR, waist circumference

OTHER: VO2 max, indirect calorimetry, U-13C palmitate infusion, 1,2-13C acetate infusion, free fatty acids, glucose, glycerol, triglycerides, insulin, catecholamines

Notes

All upper body obese. Lower body obese participants were not part of a randomised controlled trial. Variance for change in weight with interventions not reported therefore results reported narratively only.

Allocation concealment $\mathrm{B}-$ Unclear

\begin{tabular}{|c|c|}
\hline Study & Aggel-Leijssen 2002 \\
\hline Methods & $\begin{array}{l}\text { DESIGN: Parallel; Randomisation method not stated } \\
\text { BLINDING: } \\
\text { patients - not stated } \\
\text { caregivers - not stated } \\
\text { outcome assessors - not stated } \\
\text { DURATION OF INTERVENTION: } 12 \text { weeks } \\
\text { DROPOUTS: } 10 \% \\
\text { Analysis by treatment received }\end{array}$ \\
\hline Participants & $\begin{array}{l}\text { COUNTRY: Netherlands } \\
\text { n: } 24 \\
\text { AGE: N=43.4 years } \\
\text { MALES=all } \\
\text { WEIGHT ENTRY CRITERIA: BMI > } 27 \\
\text { EXCLUSION CRITERIA: poor physical health, use of medication known to influence the variables mea- } \\
\text { sured, }>3 \text { kg body weight change during } 2 \text { months before selection, }>2 \text { hours a week in sports activities, } \\
\text { physically demanding job }\end{array}$ \\
\hline Interventions & $\begin{array}{l}\text { INTERVENTION } 1(\mathrm{n}=8) \text { : cycle ergometry } 3 \text { days a week for } 33 \text { minutes at } 70 \% \text { VO2max } \\
\text { INTERVENTION } 2(\mathrm{n}=8) \text { : cycle ergometry } 3 \text { days a week for } 57 \text { minutes at } 40 \% \text { VO2max } \\
\text { CONTROL }(\mathrm{n}=8) \text { : no intervention FOLLOW-UP: } 12 \text { weeks }\end{array}$ \\
\hline Outcomes & $\begin{array}{l}\text { BODY MEASURES: weight loss }(\mathrm{kg}) \text {, BMI, hydrostatic weighing } \\
\text { OTHER: VO2 max, U-13C palmitate infusion, 1,2-13C acetate infusion, free fatty acids, glucose, glycerol } \\
\text { triglycerides }\end{array}$ \\
\hline Notes & Variance for change in weight with interventions not reported therefore results reported narratively only. \\
\hline a concealment & \\
\hline
\end{tabular}

\begin{tabular}{|c|c|}
\hline Study & Anderson 1999 \\
\hline Methods & $\begin{array}{l}\text { DESIGN: Parallel; Randomisation method not stated } \\
\text { BLINDING: } \\
\text { patients - not stated } \\
\text { caregivers - not stated } \\
\text { outcome assessors - yes } \\
\text { DURATION OF INTERVENTION: } 16 \text { weeks } \\
\text { DROPOUTS: } 2 \% \\
\text { Analysis by treatment received }\end{array}$ \\
\hline Participants & $\begin{array}{l}\text { COUNTRY: USA } \\
\text { n: } 40 \\
\text { AGE: N=42.9 years } \\
\text { MALES=none } \\
\text { WEIGHT ENTRY CRITERIA: minimum of } 15 \mathrm{~kg} \text { overweight (Metropolitan Life Insurance tables) } \\
\text { EXCLUSION CRITERIA: subjects with bulimia nervosa, binge eating disorder, significant depression, } \\
\text { and other psychiatric disturbances, identified contra indications to diet, exercise or both, including recent }\end{array}$ \\
\hline
\end{tabular}




\section{Characteristics of included studies (Continued)}

myocardial infarction, a history of cerebrovascular, kidney, or liver disease, cancer type 1 diabetes mellitus, pregnancy or use of medications known to affect weight or energy expenditure

Interventions $\quad$ INTERVENTION 1 ( $\mathrm{n}=20)$ : low fat, low calorie diet of $1200 \mathrm{kcal}$ a day + structured aerobic exercise by step aerobics 3 days a week for 45 minutes a session at intensity of $7-8.5$ METS with bursts to $10.5-11$ METS

INTERVENTION 2 ( $\mathrm{n}=20)$ : low fat, low calorie diet as above + instruction to increase levels of moderate intensity physical activity in their daily life by 30 minutes per day most days of the week FOLLOW-UP: 16 weeks

Outcomes BODY MEASURES: weight loss (kg), DXA body composition

OTHER: treadmill testing, lipids, lipoproteins, mood

\begin{tabular}{|c|c|}
\hline \multicolumn{2}{|l|}{ Notes } \\
\hline Allocation concealment & B - Unclear \\
\hline Study & Anderssen 1996 \\
\hline Methods & $\begin{array}{l}\text { DESIGN: Factorial; Randomisation method not stated } \\
\text { BLINDING: } \\
\text { patients - not stated } \\
\text { caregivers - not stated } \\
\text { outcome assessors - not stated } \\
\text { DURATION OF INTERVENTION: } 52 \text { weeks } \\
\text { DROPOUTS: } 1 \% \\
\text { Analysis by treatment received }\end{array}$ \\
\hline Participants & $\begin{array}{l}\text { COUNTRY: Norway } \\
\mathrm{n}: 219 \\
\text { AGE: all over } 40 \text { years } \\
\text { MALES=not stated } \\
\text { WEIGHT ENTRY CRITERIA: BMI > } 24 \\
\text { EXCLUSION CRITERIA: }>1 \text { workout per week, diastolic blood pressure outside } 86-99 \mathrm{~mm} \mathrm{Hg} \text {, cholesterol } \\
\text { outside } 5.2-7.74 \text { mmol / L, HDL }>1.2 \text {, fasting triglycerides }<1.4\end{array}$ \\
\hline$\overline{\text { Interventions }}$ & $\begin{array}{l}\text { INTERVENTION } 1 \text { ( } n=54) \text { :walk / jog, aerobics or circuit training for } 3 \text { days a week at } 60-80 \% \text { maximum } \\
\text { heart rate } \\
\text { INTERVENTION } 2 \text { ( } n=55) \text { : low fat diet } \\
\text { INTERVENTION } 3 \text { ( } n=67) \text { : low fat diet + exercise regimen as outlined above } \\
\text { CONTROL ( }=43) \text { : no intervention } \\
\text { FOLLOW-UP: } 52 \text { weeks }\end{array}$ \\
\hline Outcomes & $\begin{array}{l}\text { BODY MEASURES: BMI } \\
\text { OTHER: BP, cholesterol, triglycerides, insulin, glucose, VO2 max, factor VII, total energy intake }\end{array}$ \\
\hline Notes & No raw scores for weight loss in kilograms provided. \\
\hline Allocation concealment & B - Unclear \\
\hline
\end{tabular}

\section{Study}

Balkestein 1999

Methods

DESIGN: Parallel; Randomisation method not stated

BLINDING:

patients - not stated

caregivers - not stated

outcome assessors - not stated

DURATION OF INTERVENTION: 12 weeks

DROPOUTS: $11 \%$

Analysis by treatment received 


Characteristics of included studies (Continued)
COUNTRY: The Netherlands
n: 37
AGE: N=37 years
MALES=all
WEIGHT ENTRY CRITERIA: BMI between 27 and 40
EXCLUSION CRITERIA: levels of physical activity more than 2 hours a week in sports or physically de-
manding labour, diabetes, respiratory disease, cardiovascular disorders other than mild hypertension, medi-
cation use, diet, psychiatric disorders and impairment of ability to exert physical activity

\begin{tabular}{|c|c|}
\hline Study & Cox 1996 \\
\hline Methods & $\begin{array}{l}\text { DESIGN: Parallel; Randomisation method not stated } \\
\text { BLINDING: } \\
\text { patients - not stated } \\
\text { caregivers - not stated } \\
\text { outcome assessors - not stated } \\
\text { DURATION OF INTERVENTION: } 16 \text { weeks } \\
\text { DROPOUTS: } 15 \% \\
\text { Analysis by treatment received }\end{array}$ \\
\hline Participants & $\begin{array}{l}\text { COUNTRY: Australia } \\
\text { n: } 60 \\
\text { AGE: } 20-50 \text { years } \\
\text { MALES=all } \\
\text { WEIGHT ENTRY CRITERIA: } 120-160 \% \text { of ideal body weight } \\
\text { EXCLUSION CRITERIA: cigarette smoking, alcohol consumption }>210 \mathrm{ml} / \text { week, weight loss of }>10 \mathrm{~kg} \\
\text { in the preceding } 12 \text { months, hypertension, history of myocardial infarction, stroke, coronary bypass surgery, } \\
\text { renal or hepatic disease, diabetes mellitus, asthma, musculoskeletal exercise that precludes exercise }\end{array}$ \\
\hline Interventions & $\begin{array}{l}\text { INTERVENTION } 1(\mathrm{n}=13) \text { : vigorous intensity stationary cycling exercise } 3 \text { days a week for } 30 \text { minutes at } \\
60-70 \% \text { maximum heart rate } \\
\text { INTERVENTION } 2 \text { ( } \mathrm{n}=17) \text { : light exercise by flexibility stretching once a week and stationary cycling against } \\
\text { zero resistance twice a week or slow walking ( }<2 \mathrm{~km} \text { in } 30 \text { minutes) } \\
\text { FOLLOW-UP: } 16 \text { weeks }\end{array}$ \\
\hline Outcomes & $\begin{array}{l}\text { BODY MEASURES: weight loss }(\mathrm{kg}) \\
\text { OTHER: dietary compliance, physical fitness assessment, BP, alcohol, biochemistry }\end{array}$ \\
\hline \multicolumn{2}{|l|}{ Notes } \\
\hline Allocation concealment & B - Unclear \\
\hline
\end{tabular}

\begin{tabular}{ll} 
Study & Cox 2004 \\
\hline Methods & DESIGN: Factorial; Randomisation method not stated \\
& BLINDING: \\
patients - not stated \\
caregivers - not stated \\
outcome assessors - not stated
\end{tabular}


Characteristics of included studies (Continued)

\begin{tabular}{|c|c|}
\hline & $\begin{array}{l}\text { DURATION OF INTERVENTION: } 16 \text { weeks } \\
\text { DROPOUTS: } 15 \% \\
\text { Analysis by treatment received }\end{array}$ \\
\hline Participants & $\begin{array}{l}\text { COUNTRY: Australia } \\
\text { n: } 51 \\
\text { AGE: } 20-50 \text { years } \\
\text { MALES=all } \\
\text { WEIGHT ENTRY CRITERIA: } 120-160 \% \text { of ideal weight for height } \\
\text { EXCLUSION CRITERIA: Weight loss of }>10 \mathrm{~kg} \text { in the preceding } 12 \text { months, greater than two } 30 \text {-minute } \\
\text { sessions of vigorous exercise per week in the previous } 6 \text { months, musculoskeletal injury that precluded } \\
\text { exercise, non-steroidal anti-inflammatory drugs, history of diabetes, asthma or heart, renal or hepatic disease, } \\
\text { blood pressure not } 130-160 \text { systolic and } 80-100 \text { diastolic, taking antihypertensive medication, alcohol } \\
\text { consumption }>210 \mathrm{~mL} / \mathrm{wk} \text {. }\end{array}$ \\
\hline Interventions & $\begin{array}{l}\text { INTERVENTION } 1 \text { ( } \mathrm{n}=17) \text { : normal energy intake }+ \text { light exercise (flexibility exercises once a week and } \\
\text { stationary cycling against zero resistance twice a week for } 30 \text { mins. Every second week subjects substituted } \\
\text { one cycling session for a slow walking session of }<=2 \mathrm{~km} \text { in } 30 \text { mins) INTERVENTION } 2(\mathrm{n}=13) \text { : normal } \\
\text { energy intake + vigorous exercise (stationary cycling for } 30 \text { mins at } 60-70 \% \text { maximum workload } 3 \text { times a } \\
\text { week) } \\
\text { INTERVENTION } 3(\mathrm{n}=14) \text { : low energy intake + light exercise (reduced daily intake by } 1000-1500 \mathrm{kcal} / \mathrm{d} \text { ) } \\
\text { INTERVENTION } 4(\mathrm{n}=15) \text { : low energy intake + vigorous exercise FOLLOW-UP: } 16 \text { weeks }\end{array}$ \\
\hline Outcomes & $\begin{array}{l}\text { BODY MEASURES: weight loss }(\mathrm{kg}), \mathrm{WHR}, \mathrm{BMI} \\
\text { OTHER: HbA1c, insulin, glucose, VO2 max, total energy intake, dietary components }\end{array}$ \\
\hline \multicolumn{2}{|l|}{ Notes } \\
\hline Allocation concealment & B - Unclear \\
\hline
\end{tabular}

Study

Gillett 1987

Methods

DESIGN: Parallel; Randomisation method by random number table

BLINDING:

patients - not stated

caregivers - not stated

outcome assessors - not stated

DURATION OF INTERVENTION: 16 weeks

DROPOUTS: $6 \%$

Analysis by treatment received

\begin{tabular}{ll}
\hline Participants & COUNTRY: USA \\
& n: 38
\end{tabular}

AGE: $\mathrm{N}=49$ years

MALES=none

WEIGHT ENTRY CRITERIA: mean $\%$ body fat $42.5+/-7.1 \%$

EXCLUSION CRITERIA: smokers, hypertension, pregnancy, non-sedentary for 6 months prior to the study, known coronary heart disease

\begin{tabular}{ll}
\hline Interventions & INTERVENTION $1(\mathrm{n}=20)$ : dance exercise up to 53 minutes a session at 60-80 \% of maximum heart rate \\
& INTERVENTION 2 ( $\mathrm{n}=18)$ : commercial aerobics for up to 53 minutes a session at 70-80\% of maximum \\
& heart rate \\
& FOLLOW-UP: 16 weeks \\
\hline Outcomes & BODY MEASURES: weight loss (lb), body fat \% \\
& OTHER: muscular endurance, flexibility, VO2 max, cholesterol, triglyceride, glucose, HDL, blood pressure, \\
& resting heart rate \\
\hline Notes & Variance for change in weight with interventions not reported therefore results reported narratively only. \\
\hline Exercise for overweight or obesity (Review) \\
Copyright @ $\mathbf{2 0 0 7}$ The Cochrane Collaboration. Published by John Wiley \& Sons, Ltd
\end{tabular}


Allocation concealment $\mathrm{B}$ - Unclear

\begin{tabular}{|c|c|}
\hline Study & Gordon 1997 \\
\hline Methods & $\begin{array}{l}\text { DESIGN: Parallel; Randomisation method not stated } \\
\text { BLINDING: } \\
\text { patients - not stated } \\
\text { caregivers - not stated } \\
\text { outcome assessors - not stated } \\
\text { DURATION OF INTERVENTION: } 12 \text { weeks } \\
\text { DROPOUTS: } 13 \% \\
\text { Analysis by treatment received }\end{array}$ \\
\hline Participants & $\begin{array}{l}\text { COUNTRY: USA } \\
\text { n: } 55 \\
\text { AGE: N=48 years } \\
\text { MALES }=31 \% \\
\text { WEIGHT ENTRY CRITERIA: percentage body fat }>27 \% \\
\text { EXCLUSION CRITERIA: known cardiovascular disease apart from hypertension, }>15 \text { minutes of contin- } \\
\text { uous aerobic exercise }>2 \text { days a week during the previous } 3 \text { months, contraindications to maximal exercise } \\
\text { testing, participation in dietary program aimed at weight reduction, consumption of }>3 \text { alcoholic drinks a } \\
\text { day, pregnancy, lactation, current use of antihypertensive medication }\end{array}$ \\
\hline Interventions & $\begin{array}{l}\text { INTERVENTION } 1(\mathrm{n}=15) \text { :low fat, low calorie diet } \\
\text { INTERVENTION } 2(\mathrm{n}=14) \text { : aerobic exercise (predominantly walking) } 3 \text { to } 5 \text { days a week for } 30 \text { to } 45 \\
\text { minutes at } 60-85 \% \text { of maximum heart rate } \\
\text { INTERVENTION } 3(\mathrm{n}=19) \text { : diet and exercise as described above } \\
\text { FOLLOW-UP: } 12 \text { weeks }\end{array}$ \\
\hline Outcomes & $\begin{array}{l}\text { BODY MEASURES: weight loss }(\mathrm{kg}) \text {, skinfold thickness } \\
\text { OTHER: food diary, heart rate monitoring, BP, treadmill testing, maximal oxygen uptake }\end{array}$ \\
\hline Notes & All subjects had hypertension. \\
\hline
\end{tabular}

\begin{tabular}{ll} 
Study & Hays 2004 \\
\hline Methods & DESIGN: Parallel; Randomisation method not stated \\
& BLINDING: \\
patients - not stated \\
caregivers - not stated \\
outcome assessors - not stated \\
DURATION OF INTERVENTION: 12 weeks \\
DROPOUTS: $\%$ \\
Analysis by treatment received \\
COUNTRY: USA \\
n: 34 \\
AGE: N=66 years \\
MALES:N = 14 \\
WEIGHT ENTRY CRITERIA: participants stated as overweight (method not stated but BMI, \% body fat \\
and body weight reported) \\
EXCLUSION CRITERIA: current smoker, $>2$ d/wk of structured physical activity, weight unstable in past \\
6 months (+/- $>5$ kg), normal OGTT, taking medication known to affect glucose metabolism
\end{tabular}




\section{Characteristics of included studies (Continued)}

INTERVENTION 2 ( $\mathrm{n}=11)$ : low fat, high carbohydrate diet

INTERVENTION 3 ( $\mathrm{n}=12)$ : control

FOLLOW-UP: 14 weeks

Outcomes $\quad$ BODY MEASURES: weight loss (kg), BMI, \% body fat (BOD POD)

OTHER: macronutrient intake, reported physical activity, maximal aerobic capacity, resting energy expenditure, resting respiratory exchange ratio, change in fat and lean tissue cross-sectional area of the thigh

Notes

Allocation concealment $\mathrm{B}-$ Unclear

\begin{tabular}{|c|c|}
\hline Study & Hellenius 1993 \\
\hline Methods & $\begin{array}{l}\text { DESIGN: Parallel; Randomisation method not stated } \\
\text { BLINDING: } \\
\text { patients - not stated } \\
\text { caregivers - not stated } \\
\text { outcome assessors - not stated } \\
\text { DURATION OF INTERVENTION: } 26 \text { weeks } \\
\text { DROPOUTS: } 1 \% \\
\text { Analysis by treatment received }\end{array}$ \\
\hline Participants & $\begin{array}{l}\text { COUNTRY: USA } \\
\text { n: } 157 \\
\text { AGE: N=46.2 years } \\
\text { MALES= all } \\
\text { WEIGHT ENTRY CRITERIA: mean BMI }=25.3 \\
\text { EXCLUSION CRITERIA: poor general health, history of cardiovascular disease, diabetes, regular use of } \\
\text { medications, serum cholesterol not between } 5.2-7.8 \mathrm{mmol} / \mathrm{L} \text {, fasting triglycerides }>5.6 \mathrm{mmol} / \mathrm{L} \text {, fasting blood } \\
\text { glucose }>6.7 \mathrm{mmol} / \mathrm{L} \text {, diastolic blood pressure }>100 \mathrm{mmHg}\end{array}$ \\
\hline Interventions & $\begin{array}{l}\text { INTERVENTION } 1(\mathrm{n}=40) \text { : low fat, low calorie diet } \\
\text { INTERVENTION } 2(\mathrm{n}=39) \text { : walk / jog } 2-3 \text { days a week at } 60-80 \% \text { of maximum heart rate for } 30-45 \\
\text { minutes } \\
\text { INTERVENTION } 3 \text { ( } \mathrm{n}=39) \text { : diet and exercise as described above } \\
\text { CONTROL (n=39): no intervention } \\
\text { FOLLOW-UP: } 26 \text { weeks }\end{array}$ \\
\hline Outcomes & $\begin{array}{l}\text { BODY MEASURES: BMI, waist circumference, WHR } \\
\text { OTHER: food diary, blood pressure, serum cholesterol and triglycerides }\end{array}$ \\
\hline \multicolumn{2}{|l|}{ Notes } \\
\hline Allocation concealment & B - Unclear \\
\hline Study & Irwin 2003 \\
\hline Methods & $\begin{array}{l}\text { DESIGN: Parallel; Randomisation method by random number generation } \\
\text { BLINDING: } \\
\text { patients - not stated } \\
\text { caregivers - not stated } \\
\text { outcome assessors - for DXA scans } \\
\text { DURATION OF INTERVENTION: } 52 \text { weeks } \\
\text { DROPOUTS: } 2 \% \\
\text { Analysis by intention to treat }\end{array}$ \\
\hline Participants & $\begin{array}{l}\text { COUNTRY: USA } \\
\text { n: } 173 \\
\text { AGE: } 50 \text { - } 75 \text { years } \\
\text { MALES = none }\end{array}$ \\
\hline
\end{tabular}




\section{Characteristics of included studies (Continued)}

WEIGHT ENTRY CRITERIA: BMI $>=24$ and $>33 \%$ body fat

EXCLUSION CRITERIA: non- postmenopausal, non-sedentary ( $>60 \mathrm{mins} / \mathrm{wk}$ of moderate and vigorous intensity recreational activity and maximal oxygen consumption $>25 \mathrm{~mL} / \mathrm{kg} / \mathrm{min}$, taking hormone replacement therapy, diabetes, smokers

Interventions $\quad$ INTERVENTION (n=87): 45 mins of moderate intensity exercise $5 \mathrm{~d} /$ wk for 12 months (aim $60-75 \%$ MHR for 45 mins per session).

CONTROL ( $\mathrm{n}=86)$ : weekly 45 -minute stretching sessions for 1 year

FOLLOW-UP: 52 weeks

Outcomes BODY MEASURES: weight, height, waist and hip circumference, DXA total body fat and body fat \%, CT intra- abdominal and subcutaneous fat

OTHER: food frequency questionnaire, Minnesota Physical Activity Questionnaire, VO2 max

\begin{tabular}{ll}
\hline Notes & \\
\hline Allocation concealment $\quad \mathrm{B}$ - Unclear \\
\hline
\end{tabular}

\begin{tabular}{|c|c|}
\hline Study & Jakicic 1995 \\
\hline Methods & $\begin{array}{l}\text { DESIGN: Parallel; Randomisation method not stated } \\
\text { BLINDING: } \\
\text { patients - not stated } \\
\text { caregivers - not stated } \\
\text { outcome assessors - not stated } \\
\text { DURATION OF INTERVENTION: } 20 \text { weeks } \\
\text { DROPOUTS: } 15 \% \\
\text { Analysis by treatment received }\end{array}$ \\
\hline Participants & $\begin{array}{l}\text { COUNTRY: USA } \\
\text { n: } 38 \\
\text { AGE: N=40.6 years } \\
\text { MALES=none } \\
\text { WEIGHT ENTRY CRITERIA: } 120-175 \% \text { of ideal body weight (Metropolitan Life Insurance tables) } \\
\text { EXCLUSION CRITERIA: medical problems that prevent participation in regular exercise \& / or calorie } \\
\text { restricted diet, medication which affects heart rate response to exercise }\end{array}$ \\
\hline Interventions & $\begin{array}{l}\text { INTERVENTION } 1 \text { ( } \mathrm{n}=25) \text { : low fat, low calorie diet }(1200-1500 \mathrm{kcal} / \text { day) + discussion of behavioral } \\
\text { strategies to modify diet and exercise + short bout exercise (multiple } 10 \text { minute bouts of exercise to a total of } \\
20-40 \text { minutes) } 5 \text { days a week at } 70 \% \text { maximum heart rate } \\
\text { INTERVENTION } 2 \text { ( } \mathrm{n}=27) \text { : low fat, low calorie diet }(1200-1500 \mathrm{kcal} / \text { day) + discussion of behavioral } \\
\text { strategies to modify diet and exercise + long bout exercise (single } 20-40 \text { minute bout of exercise) } 5 \text { days a } \\
\text { week at } 70 \% \text { maximum heart rate FOLLOW-UP: } 20 \text { weeks }\end{array}$ \\
\hline Outcomes & $\begin{array}{l}\text { BODY MEASURES: weight loss }(\mathrm{kg}), \mathrm{BMI} \\
\text { OTHER: exercise participation, food frequency questionnaires, accelerometer data, cardiorespiratory fitness, } \\
\text { resting heart rate, BP }\end{array}$ \\
\hline \multicolumn{2}{|l|}{ Notes } \\
\hline Allocation concealment & B - Unclear \\
\hline
\end{tabular}

\begin{tabular}{ll} 
Study & Jakicic $\mathbf{2 0 0 3}$ \\
\hline Methods & DESIGN: Parallel; Randomisation method not stated \\
& BLINDING: \\
patients - not stated \\
caregivers - not stated \\
outcome assessors - not stated \\
DURATION OF INTERVENTION: 52 weeks
\end{tabular}




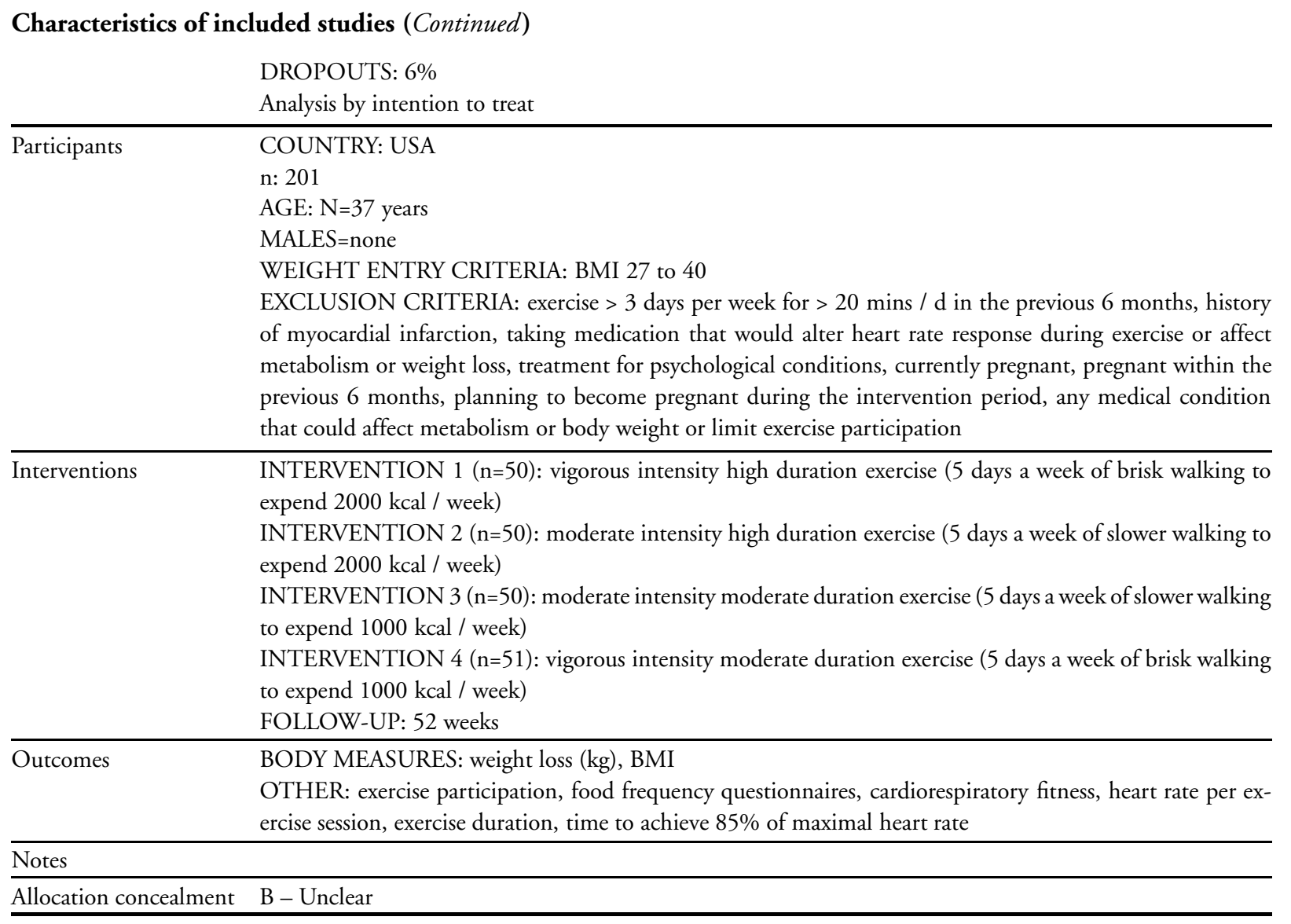

\begin{tabular}{|c|c|}
\hline Study & Janssen 2002 \\
\hline Methods & $\begin{array}{l}\text { DESIGN: Parallel; Randomisation method not stated } \\
\text { BLINDING: } \\
\text { patients - not stated } \\
\text { caregivers - not stated } \\
\text { outcome assessors - not stated } \\
\text { DURATION OF INTERVENTION: } 16 \text { weeks } \\
\text { DROPOUTS: none } \\
\text { Analysis by treatment received }\end{array}$ \\
\hline Participants & $\begin{array}{l}\text { COUNTRY: Canada } \\
\text { n: } 38 \\
\text { AGE: N=40.1 years } \\
\text { MALES=none } \\
\text { WEIGHT ENTRY CRITERIA: BMI }>27 \text { and WHR }>0.85 \\
\text { EXCLUSION CRITERIA: unstable weight in the } 6 \text { months prior to the study, taking medications, con- } \\
\text { suming greater than } 2 \text { standard alcoholic drinks a day, not premenopausal, irregular menstrual cycle }\end{array}$ \\
\hline Interventions & $\begin{array}{l}\text { INTERVENTION } 1 \text { ( } \mathrm{n}=11) \text { : low calorie diet }+ \text { aerobic exercise (treadmill walking, exercise bicycle or stair } \\
\text { stepper) } 5 \text { days a week for } 60 \text { minutes to } 50-85 \% \text { of maximum heart rate } \\
\text { INTERVENTION } 2(\mathrm{n}=14) \text { : low calorie diet + resistance training (weights machine } 3 \text { days a week for } 30 \\
\text { minutes a session until } 120 \mathrm{kcal} \text { expended) } \\
\text { INTERVENTION } 3(\mathrm{n}=13) \text { : low calorie diet only } \\
\text { FOLLOW-UP: } 16 \text { weeks }\end{array}$ \\
\hline Outcomes & BODY MEASURES: weight loss (kg), \% body fat, MRI body fat, WHR, waist circumference \\
\hline
\end{tabular}




\section{Characteristics of included studies (Continued)}

OTHER: glucose, insulin, glucose tolerance test, serum cholesterol, diet record

Notes

Allocation concealment $\mathrm{B}-$ Unclear

\begin{tabular}{|c|c|}
\hline Study & Jeffery 1998 \\
\hline Methods & $\begin{array}{l}\text { DESIGN: Factorial; Randomisation method not stated } \\
\text { BLINDING: } \\
\text { patients - not stated } \\
\text { caregivers - not stated } \\
\text { outcome assessors - not stated } \\
\text { DURATION OF INTERVENTION: } 26 \text { weeks } \\
\text { DROPOUTS: } 13 \% \\
\text { Analysis by treatment received }\end{array}$ \\
\hline Participants & $\begin{array}{l}\text { COUNTRY: USA } \\
\text { n: } 193 \\
\text { AGE: N=41 years } \\
\text { MALES }=15 \% \\
\text { WEIGHT ENTRY CRITERIA: between } 14 \text { and } 32 \mathrm{~kg} \text { overweight according to actuarial norms } \\
\text { EXCLUSION CRITERIA: serious medical complaints, unable to walk for exercise, unwilling to be random- } \\
\text { ized to treatment conditions }\end{array}$ \\
\hline Interventions & $\begin{array}{l}\text { INTERVENTION } 1(\mathrm{n}=40) \text { : standard behaviour therapy } \\
\text { INTERVENTION } 2(\mathrm{n}=41) \text { : standard behaviour therapy + supervised walks } 3 \text { days a week } \\
\text { INTERVENTION } 3(\mathrm{n}=42) \text { : standard behaviour therapy + supervised walks } 3 \text { days a week with personal } \\
\text { trainer+ reminders from personal trainer } \\
\text { INTERVENTION } 4(\mathrm{n}=37) \text { : standard behaviour therapy + supervised walks with a personal trainer + money } \\
\text { INTERVENTION } 5(\mathrm{n}=36) \text { : standard behaviour therapy + supervised walks with a personal trainer + } \\
\text { reminders + money } \\
\text { FOLLOW-UP: } 26 \text { weeks }\end{array}$ \\
\hline Outcomes & $\begin{array}{l}\text { BODY MEASURES: weight loss }(\mathrm{kg}) \\
\text { OTHER: physical activity questionnaire, food frequency questionnaire, Beck depression inventory, binge } \\
\text { eating questionnaire, barriers to adherence questionnaire }\end{array}$ \\
\hline \multicolumn{2}{|l|}{ Notes } \\
\hline Allocation concealment & B - Unclear \\
\hline
\end{tabular}

\section{Study}

Jeffery 2003

Methods

DESIGN: Parallel; Randomisation method not stated

BLINDING:

patients - not stated

caregivers - not stated

outcome assessors - not stated

DURATION OF INTERVENTION: 78 weeks

DROPOUTS: $13 \%$ at 6 months

Analysis by treatment received

Participants

COUNTRY: USA

n: 202

AGE: $\mathrm{N}=42.2$ years

MALES $=42 \%$

WEIGHT ENTRY CRITERIA: between 14 and $32 \mathrm{~kg}$ overweight according to actuarial norms EXCLUSION CRITERIA: serious medical or psychological problems thought to interfere with treatment, not aged between $25-50$ years 


\section{Characteristics of included studies (Continued)}

Interventions

INTERVENTION 1 ( $\mathrm{n}=82)$ : standard behaviour therapy

INTERVENTION 2 ( $\mathrm{n}=100)$ : standard behaviour therapy + physical activity (energy expenditure equivalent of $2500 \mathrm{kcal} / \mathrm{wk}$ )

FOLLOW-UP: 26 weeks (dropout rate $>15 \%$ at 52 and 78 weeks)

Outcomes BODY MEASURES: weight loss (kg), BMI

OTHER: Paffenbarger Physical Activity Questionnaire, Block diet questionnaire

Notes

Allocation concealment B-Unclear

Study

Methods

Kiernan 2001

DESIGN: Parallel; Randomisation method not stated

BLINDING:

patients - not stated

caregivers - not stated

outcome assessors - not stated

DURATION OF INTERVENTION: 52 weeks

DROPOUTS: $13 \%$

Analysis by treatment received

\begin{tabular}{ll}
\hline Participants & COUNTRY: USA \\
& n: 119 \\
& AGE: $N=38.5$ years \\
& MALES $=50 \%$
\end{tabular}

MALES $=50 \%$

WEIGHT ENTRY CRITERIA: BMI of 28 to 34 (males) and 24 to 30 (females)

EXCLUSION CRITERIA: smokers, non sedentary, poor health, use of blood pressure or lipid lowering medication, postmenopausal women

Interventions

INTERVENTION 1 ( $\mathrm{n}=81$ ): low fat diet + exercise by brisk walking / jogging 3 days a week for 45 minutes a session to intensity of $60-80 \%$ of maximum heart rate

INTERVENTION 2 ( $\mathrm{n}=71)$ : low fat diet only

CONTROL ( $\mathrm{n}=79)$ : waiting list control

FOLLOW-UP: 52 weeks

Outcomes BODY MEASURES: weight loss (kg), BMI

OTHER: VO2 max, eating inventory, depression inventory, aerobic capacity

Notes

Allocation concealment $\mathrm{B}-$ Unclear

\begin{tabular}{ll} 
Study & Leutholtz 1995 \\
\hline Methods & DESIGN: Parallel; Randomisation method not stated \\
& BLINDING: \\
patients - not stated & caregivers - not stated \\
& outcome assessors - not stated \\
& DURATION OF INTERVENTION: 12 weeks \\
& DROPOUTS: $0 \%$ \\
& Analysis by treatment received \\
& COUNTRY: USA \\
& n: 40 \\
& AGE: N=41 years \\
& MALES $=18 \%$ \\
WEIGHT ENTRY CRITERIA: body fat $\%>25 \%$ for men and $>30 \%$ for women
\end{tabular}

Exercise for overweight or obesity (Review)

Copyright @ 2007 The Cochrane Collaboration. Published by John Wiley \& Sons, Ltd 


\section{Characteristics of included studies (Continued)}

EXCLUSION CRITERIA: coronary or peripheral atherosclerosis, ketosis prone diabetes mellitus, chronic use of steroids, bleeding peptic ulcer, history of suicide attempts, active thrombophlebitis, alcohol abuse, pregnancy, lactation, inability to exercise, use of beta blockers or other exercise limiting medications

Interventions $\quad$ INTERVENTION 1 ( $\mathrm{n}=20)$ : liquid formula Optifast diet ( $420 \mathrm{kcal} /$ day $)+$ exercise by walking at a target heart rate of $60 \%$ of maximum heart rate to a distance that expended $300 \mathrm{kcal}$ of energy

INTERVENTION 2 ( $\mathrm{n}=20)$ : liquid formula Optifast diet (420 kcal / day) + exercise by walking at a target heart rate of $40 \%$ of maximum heart rate to a distance that expended $300 \mathrm{kcal}$ of energy FOLLOW-UP: 12 weeks

Outcomes BODY MEASURES: weight loss (kg), lean body mass, fat mass

OTHER: resting heart rate, $\mathrm{BP}, \mathrm{VO} 2 \mathrm{max}$

\begin{tabular}{ll}
\hline Notes & \\
\hline Allocation concealment $\quad \mathrm{B}-$ Unclear \\
\hline
\end{tabular}

\begin{tabular}{|c|c|}
\hline Study & Manning 1991 \\
\hline Methods & $\begin{array}{l}\text { DESIGN: Parallel; Randomisation method not stated } \\
\text { BLINDING: } \\
\text { patients - not stated } \\
\text { caregivers - not stated } \\
\text { outcome assessors - not stated } \\
\text { DURATION OF INTERVENTION: } 12 \text { weeks } \\
\text { DROPOUTS: } 9 \% \\
\text { Analysis by treatment received }\end{array}$ \\
\hline Participants & $\begin{array}{l}\text { COUNTRY: USA } \\
\text { n: } 24 \\
\text { AGE: } 22-57 \text { years } \\
\text { MALES=none } \\
\text { WEIGHT ENTRY CRITERIA: BMI > } 30 \\
\text { EXCLUSION CRITERIA: physical activity in the previous } 6 \text { months, unstable weight in the previous } 6 \\
\text { months }\end{array}$ \\
\hline Interventions & $\begin{array}{l}\text { INTERVENTION ( } \mathrm{n}=40) \text { : strength training with weights } 3 \text { days a week for } 12 \text { weeks to } 60-70 \% \text { of maximum } \\
\text { heart rate } \\
\text { CONTROL }(\mathrm{n}=6) \text { : no intervention } \\
\text { FOLLOW-UP: } 12 \text { weeks }\end{array}$ \\
\hline Outcomes & $\begin{array}{l}\text { BODY MEASURES: weight loss }(\mathrm{kg}), \mathrm{BMI} \\
\text { OTHER: dietary record, LDL, HDL, cholesterol, triglycerides, apolipoproteins }\end{array}$ \\
\hline Notes & Variance for change in weight with interventions not reported therefore results reported narratively only. \\
\hline Allocation concealment & B - Unclear \\
\hline
\end{tabular}

\begin{tabular}{ll} 
Study & Neumark $\mathbf{1 9 9 5}$ \\
\hline Methods & DESIGN: Factorial; Randomisation method not stated \\
& BLINDING: \\
patients - not stated & caregivers - not stated \\
& outcome assessors - not stated \\
& DURATION OF INTERVENTION: 12 weeks \\
& DROPOUTS: $5 \%$ \\
& Analysis by treatment received \\
\hline Participants & COUNTRY: Israel \\
& n: 42 \\
\hline
\end{tabular}




\section{Characteristics of included studies (Continued)}

\begin{tabular}{ll} 
& AGE: 25-50 years \\
& MALES=none \\
& WEIGHT ENTRY CRITERIA: BMI $>27$ \\
& EXCLUSION CRITERIA: health problems, lack of interest in participation \\
\hline Interventions & INTERVENTION $(\mathrm{n}=19)$ : low calorie diet $(<1000 \mathrm{kcal})+$ self monitoring \\
& INTERVENTION 2 ( $\mathrm{n}=21)$ : diet + self monitoring as above + supervised aerobic exercise for 1 hour per \\
& week +15 minutes of walking / jogging 5 days a week +10 minutes of other unspecified exercise 6 days a \\
& week \\
& FOLLOW-UP: 12 weeks \\
\hline Outcomes & BODY MEASURES: weight loss $(\mathrm{kg})$, skinfold thicknesses, WHR, waist circumference, BMI \\
\hline Notes & \\
\hline Allocation concealment & B - Unclear \\
\hline
\end{tabular}

\begin{tabular}{|c|c|}
\hline Study & Nieman 1998 \\
\hline Methods & $\begin{array}{l}\text { DESIGN: Factorial; Randomisation method not stated } \\
\text { BLINDING: } \\
\text { patients - not stated } \\
\text { caregivers - not stated } \\
\text { outcome assessors - not stated } \\
\text { DURATION OF INTERVENTION: } 12 \text { weeks } \\
\text { DROPOUTS: } 11 \% \\
\text { Analysis by treatment received }\end{array}$ \\
\hline Participants & $\begin{array}{l}\text { COUNTRY: USA } \\
\text { n: } 91 \\
\text { AGE: N=45.6 years } \\
\text { MALES=none } \\
\text { WEIGHT ENTRY CRITERIA: BMI between } 25 \text { and } 65 \\
\text { EXCLUSION CRITERIA: serious medical complaints, unable to walk for exercise, unwilling to be random- } \\
\text { ized to treatment conditions }\end{array}$ \\
\hline Interventions & $\begin{array}{l}\text { INTERVENTION } 1(\mathrm{n}=21): 45 \text { minutes of walking } 5 \text { days a week at } 60-75 \% \text { maximum heart rate INTER- } \\
\text { VENTION } 2(\mathrm{n}=26): 1200-1300 \mathrm{kcal} \text { a day diet } \\
\text { INTERVENTION } 3(\mathrm{n}=22) \text { : low calorie diet and exercise as outlined above } \\
\text { INTERVENTION } 4(\mathrm{n}=22) \text { : no treatment control } \\
\text { FOLLOW-UP: } 12 \text { weeks }\end{array}$ \\
\hline Outcomes & $\begin{array}{l}\text { BODY MEASURES: weight loss }(\mathrm{kg}) \text {, body composition, body fat } \% \\
\text { OTHER: adaptive immunity, natural killer cell activity, phagocytosis and oxidative burst, aerobic power, } \\
\text { VO2 max, glucose, triglycerides, cholesterol, maximum heart rate }\end{array}$ \\
\hline Notes & $\begin{array}{l}\text { Variance for change in weight with exercise only and control interventions not reported therefore results } \\
\text { reported narratively only. }\end{array}$ \\
\hline Allocation concealment & B - Unclear \\
\hline
\end{tabular}

\begin{tabular}{ll} 
Study & Pritchard 1997 \\
\hline Methods & DESIGN: Parallel; Randomisation method not stated \\
& BLINDING: \\
patients - not stated & caregivers - not stated \\
& outcome assessors - not stated \\
& DURATION OF INTERVENTION: 52 weeks
\end{tabular}




\section{Characteristics of included studies (Continued)}

DROPOUTS: $12 \%$

Analysis by treatment received

\begin{tabular}{ll}
\hline Participants & COUNTRY: Australia \\
& $\mathrm{n}: 39$ \\
& AGE: N=43.4 years \\
& MALES=all \\
& WEIGHT ENTRY CRITERIA: mean BMI 29 +/- 2.6 \\
& EXCLUSION CRITERIA: inability to satisfactorily complete standardized fitness test \\
\hline Interventions & INTERVENTION 1 ( $\mathrm{n}=21): 3$ sessions of 30 minutes a week of aerobic exercise of the participants choice \\
& to an intensity of $65-75 \%$ of maximum heart rate \\
& INTERVENTION 2 ( $\mathrm{n}=18):$ low fat diet \\
& FOLLOW-UP: 52 weeks \\
\hline Outcomes & MEASURES: weight loss (kg), waist circumference, WHR, body composition (DXA) \\
& OTHER: 24 hour food recall, 3 day food diary, activity log \\
\hline Notes & B - Unclear \\
\hline Allocation concealment &
\end{tabular}

\begin{tabular}{|c|c|}
\hline Study & Raz 1994 \\
\hline Methods & $\begin{array}{l}\text { DESIGN: Parallel; Randomisation method not stated } \\
\text { BLINDING: } \\
\text { patients - not stated } \\
\text { caregivers - not stated } \\
\text { outcome assessors - not stated } \\
\text { DURATION OF INTERVENTION: } 12 \text { weeks } \\
\text { DROPOUTS: none } \\
\text { Analysis by treatment received }\end{array}$ \\
\hline Participants & $\begin{array}{l}\text { COUNTRY: Israel } \\
\text { n: } 40 \\
\text { AGE: N=56.6 years } \\
\text { MALES }=35 \% \\
\text { WEIGHT ENTRY CRITERIA: BMI > } 25 \\
\text { EXCLUSION CRITERIA: Ischaemic heart disease, systolic hypertension, inability to use a bicycle ergometer, } \\
\text { unwillingness to accept control group treatment assignment }\end{array}$ \\
\hline Interventions & $\begin{array}{l}\text { INTERVENTION ( } \mathrm{n}=19) \text { : } 45 \text { mins of cycle ergometry, treadmill and or rowing machine to } 65 \% \text { of VO } 2 \\
\text { max for } 3 \text { days a week } \\
\text { CONTROL ( } n=19) \text { : no change to lifestyle } \\
\text { FOLLOW-UP: } 12 \text { weeks }\end{array}$ \\
\hline Outcomes & $\begin{array}{l}\text { BODY MEASURES: weight loss }(\mathrm{kg}) \\
\text { OTHER: glucose, fructosamine, HbA1c, cholesterol, HDL, triglycerides, resting heart rate, maximal work } \\
\text { capacity }\end{array}$ \\
\hline Notes & Variance for change in weight with interventions not reported therefore results reported narratively only. \\
\hline Allocation concealment & B - Unclear \\
\hline Study & Ross 1996 \\
\hline Methods & $\begin{array}{l}\text { DESIGN: Parallel; Randomisation method not stated } \\
\text { BLINDING: } \\
\text { patients - not stated } \\
\text { caregivers - not stated } \\
\text { outcome assessors - not stated }\end{array}$ \\
\hline
\end{tabular}


Characteristics of included studies (Continued)

DURATION OF INTERVENTION: 16 weeks

DROPOUTS: none

Analysis by treatment received

\begin{tabular}{|c|c|}
\hline Participants & $\begin{array}{l}\text { COUNTRY: Canada } \\
\text { n: } 33 \\
\text { AGE: N=44.5 years } \\
\text { MALES=all } \\
\text { WEIGHT ENTRY CRITERIA: BMI }>27 \\
\text { EXCLUSION CRITERIA: change in weight of more than } 2 \mathrm{~kg} \text { in the previous } 6 \text { months, taking medication } \\
\text { known to affect the study variables, consumption of }>2 \text { alcoholic beverages daily }\end{array}$ \\
\hline Interventions & $\begin{array}{l}\text { INTERVENTION } 1(\mathrm{n}=11) \text { : low calorie diet }(1000 \mathrm{kcal} / \mathrm{d}) \\
\text { INTERVENTION } 2(\mathrm{n}=11) \text { : low calorie diet as above + aerobic exercise by bicycling / walking / stair stepping } \\
5 \text { days a week for } 60 \text { minutes a session } \\
\text { INTERVENTION } 3(\mathrm{n}=11) \text { : low calorie diet as outlined above + resistance exercise using a weights machine } \\
3 \text { days a week with } 8-12 \text { repetitions per session to a calculated energy expenditure of } 120 \mathrm{kcal} \text { per session } \\
\text { FOLLOW-UP: } 16 \text { weeks }\end{array}$ \\
\hline Outcomes & $\begin{array}{l}\text { BODY MEASURES: weight loss }(\mathrm{kg}) \text {, waist circumference, WHR, regional adipose tissue distribution (MRI) } \\
\text { OTHER: VO2 max, strength-training performance, dietary records }\end{array}$ \\
\hline Notes & All subjects had upper body obesity \\
\hline & B - Unclear \\
\hline
\end{tabular}

\begin{tabular}{|c|c|}
\hline Study & Schwartz 1987 \\
\hline Methods & $\begin{array}{l}\text { DESIGN: Parallel; Randomisation method not stated } \\
\text { BLINDING: } \\
\text { patients - not stated } \\
\text { caregivers - not stated } \\
\text { outcome assessors - not stated } \\
\text { DURATION OF INTERVENTION: } 12 \text { weeks } \\
\text { DROPOUTS: none } \\
\text { Analysis by treatment received }\end{array}$ \\
\hline Participants & $\begin{array}{l}\text { COUNTRY: USA } \\
\text { n: } 26 \\
\text { AGE: N=31.4 years } \\
\text { MALES=all } \\
\text { WEIGHT ENTRY CRITERIA: } 110-185 \% \text { of ideal body weight (Metropolitan Life Insurance tables) } \\
\text { EXCLUSION CRITERIA: poor health, unstable weight, cigarette smoking, use of prescription or over the } \\
\text { counter medications, participation in regular exercise }\end{array}$ \\
\hline Interventions & $\begin{array}{l}\text { INTERVENTION } 1(\mathrm{n}=12) \text { : low calorie diet }(1200 \mathrm{kcal} / \mathrm{d}) \\
\text { INTERVENTION } 2(\mathrm{n}=14) \text { : brisk walking / jogging } 3 \text { days a week for } 40 \text { minutes a session at } 70-85 \% \\
\text { maximum heart rate } \\
\text { FOLLOW-UP: } 12 \text { weeks }\end{array}$ \\
\hline Outcomes & $\begin{array}{l}\text { BODY MEASURES: weight loss }(\mathrm{kg}) \text {, body fat } \% \\
\text { OTHER: lipoproteins, total and fractionated cholesterol, VO2 max }\end{array}$ \\
\hline \multicolumn{2}{|l|}{ Notes } \\
\hline Allocation concealment & B - Unclear \\
\hline
\end{tabular}

\begin{tabular}{ll} 
Study & Schwartz 1990 \\
\hline Methods & DESIGN: Parallel; Randomisation method not stated \\
& BLINDING:
\end{tabular}




\section{Characteristics of included studies (Continued)}

\begin{tabular}{|c|c|}
\hline & $\begin{array}{l}\text { patients - not stated } \\
\text { caregivers - not stated } \\
\text { outcome assessors - not stated } \\
\text { DURATION OF INTERVENTION: } 12 \text { weeks } \\
\text { DROPOUTS: } 9 \% \\
\text { Analysis by treatment received }\end{array}$ \\
\hline Participants & $\begin{array}{l}\text { COUNTRY: USA } \\
\text { n: } 31 \\
\text { AGE: N=30.9 years } \\
\text { MALES=all } \\
\text { WEIGHT ENTRY CRITERIA: mean body fat } \% \text { of groups was } 28.4 \% \text { for the diet group and } 30.1 \% \text { for } \\
\text { the exercise group } \\
\text { EXCLUSION CRITERIA: poor health, unstable weight, cigarette smoking, participation in a regular exercise } \\
\text { program, use of prescribed or over the counter medications }\end{array}$ \\
\hline Interventions & $\begin{array}{l}\text { INTERVENTION } 1(\mathrm{n}=13) \text { : low calorie diet }(1200 \mathrm{kcal} / \mathrm{d}) \\
\text { INTERVENTION } 2(\mathrm{n}=18) \text { : brisk walking / jogging } 3 \text { days a week for } 40 \text { minutes a session at } 70-85 \% \text { of } \\
\text { maximum heart rate } \\
\text { FOLLOW-UP: } 12 \text { weeks }\end{array}$ \\
\hline Outcomes & $\begin{array}{l}\text { BODY MEASURES: weight loss }(\mathrm{kg}), \text { body fat mass, \% body fat } \\
\text { OTHER: food diary, plasma epinephrine and norepinephrine clearance, baseline pulse rate }\end{array}$ \\
\hline \multicolumn{2}{|l|}{ Notes } \\
\hline Allocation concealment & B - Unclear \\
\hline Study & Stefanick 1998 \\
\hline Methods & $\begin{array}{l}\text { DESIGN: Factorial; Randomisation by computer - the Efron method } \\
\text { BLINDING: } \\
\text { patients - no } \\
\text { caregivers - no } \\
\text { outcome assessors - not stated } \\
\text { DURATION OF INTERVENTION: } 52 \text { weeks } \\
\text { DROPOUTS: } 3 \% \\
\text { Analysis by treatment received }\end{array}$ \\
\hline Participants & $\begin{array}{l}\text { COUNTRY: USA } \\
\text { n: } 377 \\
\text { AGE: } 30-64 \text { years } \\
\text { MALES=52\% } \\
\text { WEIGHT ENTRY CRITERIA: not stated - WHR for men }>0.94 \text { and women }>0.82 \\
\text { EXCLUSION CRITERIA: elevated HDL levels, history of heart disease, stroke, diabetes, recent cancer, } \\
\text { other life-threatening illnesses or any condition limiting their ability to engage in moderate exercise, taking } \\
\text { insulin or heart medications, blood pressure or high serum cholesterol, smoking more than } 9 \text { cigarettes daily, } \\
\text { consuming more than } 4 \text { alcoholic drinks a day }\end{array}$ \\
\hline Interventions & $\begin{array}{l}\text { INTERVENTION } 1 \text { ( } \mathrm{n}=43) \text { : supervised aerobic exercise equivalent to brisk walking or jogging } 3 \text { days per } \\
\text { week for } 60 \text { minutes per session } \\
\text { INTERVENTION } 2(\mathrm{n}=46) \text { : low fat diet } \\
\text { INTERVENTION } 3 \text { ( } \mathrm{n}=43) \text { : diet and exercise as outlined above CONTROL }(\mathrm{n}=45) \text { : no change to diet or } \\
\text { exercise } \\
\text { FOLLOW-UP: } 52 \text { weeks }\end{array}$ \\
\hline Outcomes & $\begin{array}{l}\text { BODY MEASURES: weight loss }(\mathrm{kg}), \text { WHR } \\
\text { OTHER: cholesterol, triglycerides, HDL, LDL, glucose, BP, VO2max }\end{array}$ \\
\hline Notes & \\
\hline
\end{tabular}




\section{Characteristics of included studies (Continued)}

Allocation concealment $\mathrm{B}$ - Unclear

\begin{tabular}{|c|c|}
\hline Study & Stensel 1994 \\
\hline Methods & $\begin{array}{l}\text { DESIGN: Parallel; Randomisation method not stated } \\
\text { BLINDING: } \\
\text { patients - no } \\
\text { caregivers - no } \\
\text { outcome assessors - not stated } \\
\text { DURATION OF INTERVENTION: } 52 \text { weeks } \\
\text { DROPOUTS: } 10 \% \\
\text { Analysis by treatment received }\end{array}$ \\
\hline Participants & $\begin{array}{l}\text { COUNTRY: UK } \\
\text { n: } 72 \\
\text { AGE: } 42-59 \text { years } \\
\text { MALES=all } \\
\text { WEIGHT ENTRY CRITERIA: not stated - BMI was > } 25.2 \text { for participants } \\
\text { EXCLUSION CRITERIA: non-sedentary, employed in a strenuous job }\end{array}$ \\
\hline Interventions & $\begin{array}{l}\text { INTERVENTION } 1(\mathrm{n}=48) \text { : walking up to } 40-45 \text { minutes a day a minimum of } 3 \text { days a week } \\
\text { CONTROL }(\mathrm{n}=24) \text { : no change to diet or exercise } \\
\text { FOLLOW-UP: } 52 \text { weeks }\end{array}$ \\
\hline Outcomes & $\begin{array}{l}\text { BODY MEASURES: weight loss (kg), BMI, WHR, body density, \% body fat } \\
\text { OTHER: VO2 max, blood lactate, dietary intake }\end{array}$ \\
\hline Notes & Variance for change in weight with interventions not reported therefore results reported narratively only \\
\hline Allocation concealment & B - Unclear \\
\hline
\end{tabular}

\begin{tabular}{|c|c|}
\hline Study & Svendsen 1993 \\
\hline Methods & $\begin{array}{l}\text { DESIGN: Parallel; Randomisation method not stated } \\
\text { BLINDING: } \\
\text { patients - not stated } \\
\text { caregivers - not stated } \\
\text { outcome assessors - not stated } \\
\text { DURATION OF INTERVENTION: } 12 \text { weeks } \\
\text { DROPOUTS: } 3 \% \\
\text { Analysis by treatment received }\end{array}$ \\
\hline Participants & $\begin{array}{l}\text { COUNTRY: Denmark } \\
\text { n: } 121 \\
\text { AGE: N=53.8 years } \\
\text { MALES=none } \\
\text { WEIGHT ENTRY CRITERIA: BMI > } 25 \\
\text { EXCLUSION CRITERIA: menstrual bleeding in the preceding } 6 \text { months, hysterectomy, weight loss in } \\
\text { the preceding } 3 \text { months, lack of motivation or ability to participate, psychiatric illness, cardiovascular, pul- } \\
\text { monary, catabolic, renal or hepatic disease, medication known to influence body composition, hormones, } \\
\text { antihistamines and catabolic drugs }\end{array}$ \\
\hline Interventions & $\begin{array}{l}\text { INTERVENTION } 1(\mathrm{n}=51) \text { : diet only (formula diet providing } 1.6 \text { MJ daily) INTERVENTION } 2(\mathrm{n}=49) \text { : } \\
\text { supervised aerobic exercise and resistance weights training } 3 \text { days a week for } 60-90 \text { minutes per session at } \\
70 \% \text { VO2 max intensity }+ \text { diet as outlined above } \\
\text { CONTROL }(\mathrm{n}=21) \text { : no change to diet or exercise } \\
\text { FOLLOW-UP: } 12 \text { weeks }\end{array}$ \\
\hline Outcomes & $\begin{array}{l}\text { BODY MEASURES: weight loss (kg), body composition, bone mineral density, fat tissue and lean tissue } \\
\text { mass, skinfold thicknesses, WHR }\end{array}$ \\
\hline
\end{tabular}




\section{Characteristics of included studies (Continued)}

OTHER: blood pressure, pulse, food diaries, HDL, cholesterol, triglycerides, alkaline phosphatase

Notes

Allocation concealment $\mathrm{B}-$ Unclear

Study

Thong 2000

Methods

DESIGN: Parallel; Randomisation method not stated

BLINDING:

patients - not stated

caregivers - not stated

outcome assessors - not stated

DURATION OF INTERVENTION: 12 weeks

DROPOUTS: none

Analysis by treatment received

Participants COUNTRY: Canada

n: 52

AGE: $\mathrm{N}=44.4$ years

MALES=all

WEIGHT ENTRY CRITERIA: BMI > 30

EXCLUSION CRITERIA: none stated

Interventions INTERVENTION 1 ( $\mathrm{n}=14)$ : low calorie diet INTERVENTION 2 ( $\mathrm{n}=14)$ : brisk walking or jogging on a motorized treadmill daily for 12 weeks at intensity up to but not exceeding $75 \%$ of maximum heart rate CONTROL $(n=8)$ : no change to diet or exercise

FOLLOW-UP: 12 weeks

Outcomes

BODY MEASURES: weight loss (kg), BMI, waist circumference, WHR, MRI fat stores

OTHER: VO2 max, leptin levels

Notes

Allocation concealment $\mathrm{B}-$ Unclear

Study Utter 2000

Methods DESIGN: Parallel; Randomisation method not stated

BLINDING:

patients - not stated

caregivers - not stated

outcome assessors - not stated

DURATION OF INTERVENTION: 12 weeks

DROPOUTS: $4 \%$

Analysis by treatment received

Participants COUNTRY: USA

n: 27

AGE: $\mathrm{N}=42.3$ years

MALES=none

WEIGHT ENTRY CRITERIA: BMI between 25-34

EXCLUSION CRITERIA: physically active $>3$ moderate to vigorous aerobic sessions of greater than 20 mins duration per week, poor health, diabetes, cancer, heart disease, cigarette smoking, history of gastrointestinal disease, gallstones, gallbladder sludge or other pathology of the gallbladder, currently on weight reduction diet, weight loss of $>5 \%$ in the previous 3 months

Interventions

INTERVENTION 1 ( $n=16)$ : walking 5 days a week, 45 mins a session to intensity of $60-80 \%$ of maximum heart rate

CONTROL ( $\mathrm{n}=11)$ : no change to diet or exercise 


\section{Characteristics of included studies (Continued)}

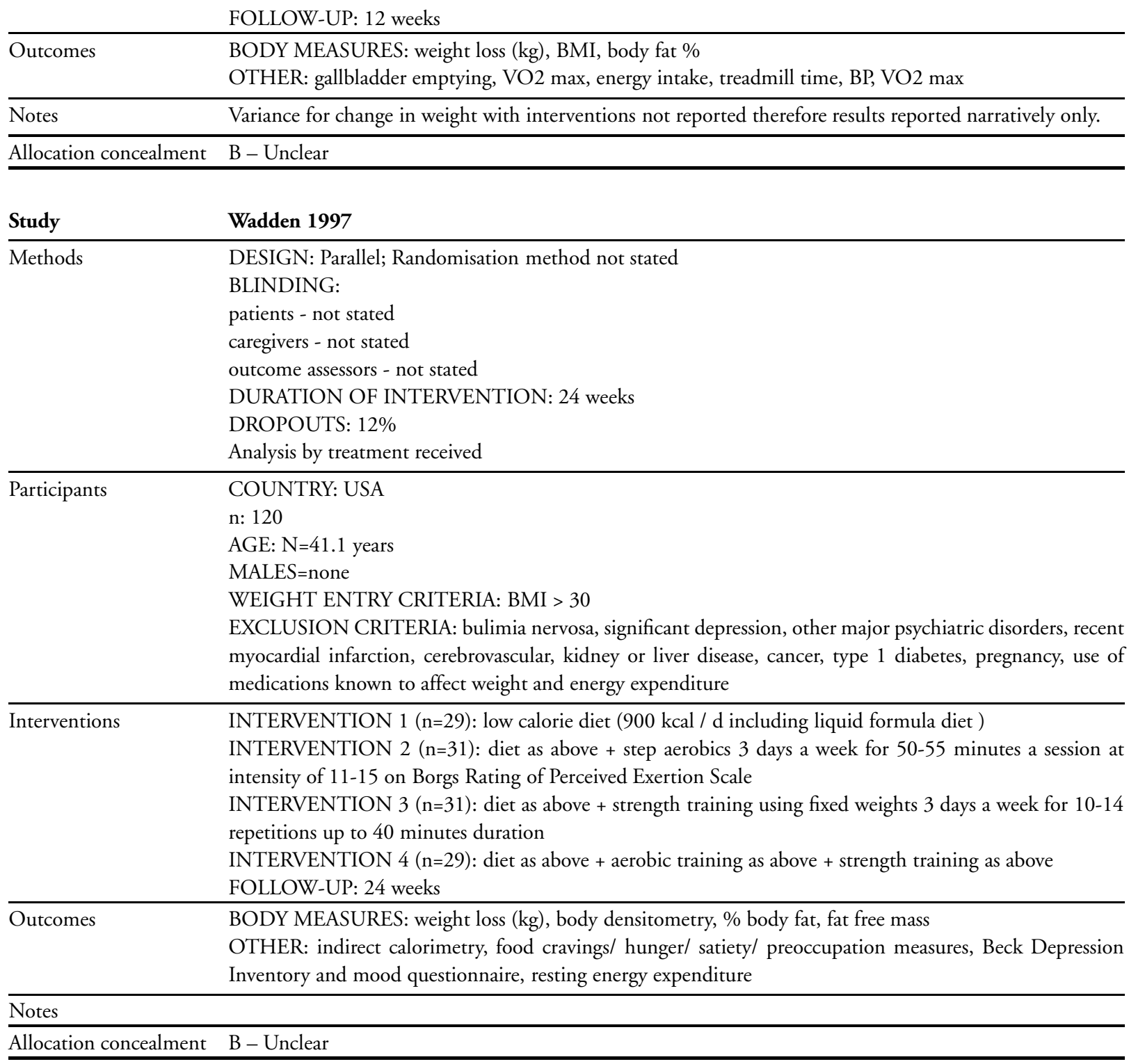

\begin{tabular}{ll} 
Study & Wallace $\mathbf{1 9 9 7}$ \\
\hline Methods & DESIGN: Parallel; Randomisation method not stated \\
& BLINDING: \\
patients - not stated & caregivers - not stated \\
outcome assessors - not stated & DURATION OF INTERVENTION: 14 weeks \\
& DROPOUTS: none \\
Analysis by treatment received & COUNTRY: USA \\
n: 16 \\
AGE: N=41.2 years \\
PALES=all
\end{tabular}


Characteristics of included studies (Continued)

WEIGHT ENTRY CRITERIA: WHR>1.02

EXCLUSION CRITERIA: non- hyper insulinaemic, non-sedentary, non- dyslipidaemic, normotensive

Interventions $\quad$ INTERVENTION $1(\mathrm{n}=8): 60$ mins of aerobic exercise (30 minutes each of cycle ergometry and treadmill walking) at 60-70\% maximum heart rate for 3 days a week

INTERVENTION 2 ( $\mathrm{n}=8)$ : endurance training as above + resistance weights for 8-12 sets at intensity of $75 \% 1 \mathrm{RM}$

FOLLOW-UP: 14 weeks

Outcomes $\quad$ BODY MEASURES: weight loss (kg), \% body fat, WHR, body composition

OTHER: electrolytes strength testing

Notes

Allocation concealment $\mathrm{B}-$ Unclear

Study Whatley 1994

Methods DESIGN: Parallel; Randomisation method not stated

BLINDING:

patients - not stated

caregivers - not stated

outcome assessors - not stated

DURATION OF INTERVENTION: 12 weeks

DROPOUTS: none

Analysis by treatment received

Participants COUNTRY: USA

n: 23

AGE: $\mathrm{N}=38.5$ years

MALES=none

WEIGHT ENTRY CRITERIA: BMI between 30 and 42

EXCLUSION CRITERIA: significant medical illness, unstable weight or participation in weight loss activities in the previous 6 months

Interventions $\quad$ INTERVENTION 1 ( $\mathrm{n}=7)$ : very low energy liquid formula diet

INTERVENTION 2 ( $n=8)$ : very low energy liquid formula diet + walking and weights training 3 days a week at $50-65 \%$ of maximum heart rate

INTERVENTION 3 (n=8): very low energy liquid formula diet + walking 5 days a week and weights training 3 days a week at 50-65\% of maximum heart rate FOLLOW-UP: 12 weeks

Outcomes BODY MEASURES: weight loss (kg), \% body fat, WHR

OTHER: VO2 max, resting metabolic rate

Notes

Allocation concealment $\mathrm{B}$ - Unclear

Study Wing 1988

Methods

DESIGN: Parallel; Randomisation method not stated

BLINDING:

patients - no

caregivers - no

outcome assessors - yes

DURATION OF INTERVENTION: 52 weeks

DROPOUTS: 7\%

Analysis by treatment received

Participants

COUNTRY: USA

n: 30 


\section{Characteristics of included studies (Continued)}

\begin{tabular}{|c|c|}
\hline & $\begin{array}{l}\text { AGE: } \mathrm{N}=55.6 \text { years } \\
\text { MALES=not stated } \\
\text { WEIGHT ENTRY CRITERIA: }>120 \% \text { of ideal body weight } \\
\text { EXCLUSION CRITERIA: non- diabetic, not aged between } 30 \text { and } 65 \text { years, history of coronary heart } \\
\text { disease, taking medications which could interfere with weight loss or heart rate during exercise, orthopaedic } \\
\text { problems that would limit walking }\end{array}$ \\
\hline Interventions & $\begin{array}{l}\text { INTERVENTION } 1(\mathrm{n}=15) \text { : walking } 3 \text { miles four days a week + low calorie diet calculated to produce } 1 \mathrm{~kg} \\
\text { / wk weight loss } \\
\text { INTERVENTION } 2(\mathrm{n}=15) \text { : low calorie diet only } \\
\text { FOLLOW-UP: } 52 \text { weeks }\end{array}$ \\
\hline Outcomes & $\begin{array}{l}\text { BODY MEASURES: weight loss }(\mathrm{kg}), \mathrm{BMI} \\
\text { OTHER: HbA1c, cholesterol, triglycerides, BP, glucose, insulin }\end{array}$ \\
\hline Notes & $\begin{array}{l}\text { All type } 2 \text { diabetes. Variance for change in weight with interventions not reported therefore results reported } \\
\text { narratively only. }\end{array}$ \\
\hline Allocation concealment & B - Unclear \\
\hline Study & Wing 1998 \\
\hline Methods & $\begin{array}{l}\text { DESIGN: Parallel; Randomisation method not stated } \\
\text { BLINDING: } \\
\text { patients - not stated } \\
\text { caregivers - not stated } \\
\text { outcome assessors - not stated } \\
\text { DURATION OF INTERVENTION: } 26 \text { weeks } \\
\text { DROPOUTS: } 15 \% \\
\text { Analysis by treatment received }\end{array}$ \\
\hline Participants & $\begin{array}{l}\text { COUNTRY: USA } \\
\text { n: } 154 \\
\text { AGE: } N=45.7 \text { years } \\
\text { MALES }=21 \% \\
\text { WEIGHT ENTRY CRITERIA: } 130-200 \% \text { of ideal body weight } \\
\text { EXCLUSION CRITERIA: diabetics, no family history of diabetes }\end{array}$ \\
\hline Interventions & $\begin{array}{l}\text { INTERVENTION } 1 \text { ( } \mathrm{n}=37) \text { : walking for } 50-60 \text { minutes up to } 5 \text { days a week to expend } 1500 \text { kcal a week } \\
\text { INTERVENTION } 2 \text { ( } \mathrm{n}=37) \text { : low calorie, low fat diet } \\
\text { INTERVENTION } 3 \text { ( } \mathrm{n}=40) \text { : low fat, low calorie diet }+ \text { aerobic exercise as outlined above } \\
\text { CONTROL ( } \mathrm{n}=40) \text { : given self-help behavioral manual with information on healthy eating, exercise and } \\
\text { behavioral strategies for weight control } \\
\text { FOLLOW-UP: } 26 \text { weeks }\end{array}$ \\
\hline Outcomes & $\begin{array}{l}\text { BODY MEASURES: weight loss }(\mathrm{kg}) \text {, waist circumference, WHR } \\
\text { OTHER: glucose tolerance test, insulin, fasting glucose, HbA1c, cholesterol and triglycerides, HDL, blood } \\
\text { pressure, physical activity assessment, food frequency measures }\end{array}$ \\
\hline Notes & All subjects had a family history of non-insulin dependent diabetes mellitus. \\
\hline Allocation concealment & B - Unclear \\
\hline Study & Wirth 1985 \\
\hline Methods & $\begin{array}{l}\text { DESIGN: Parallel; Randomisation method not stated } \\
\text { BLINDING: } \\
\text { patients - not stated } \\
\text { caregivers - not stated } \\
\text { outcome assessors - not stated }\end{array}$ \\
\hline
\end{tabular}


Characteristics of included studies (Continued)

DURATION OF INTERVENTION: 16 weeks

DROPOUTS: 7\%

Analysis by treatment received

\begin{tabular}{ll}
\hline Participants & COUNTRY: Germany \\
& n: 21 \\
& AGE: N=43 years \\
& MALES=all \\
& WEIGHT ENTRY CRITERIA: not stated - mean body fat $\%=24$ \\
& EXCLUSION CRITERIA: no hyper triglyceridaemia \\
\hline Interventions & INTERVENTION 1 ( $\mathrm{n}=10)$ : jogging, ball games and calisthenics 3 times a week for 1 hour to achieve a \\
& pulse between 120 and 150 beats per minute \\
& CONTROL (n=11): no treatment \\
& FOLLOW-UP: 16 weeks \\
\hline Outcomes & BODY MEASURES: weight loss (kg) \\
& OTHER: cholesterol, LDL, HDL, apo lipoprotein A1, insulin, blood pressure, body fat \%, energy expendi- \\
& ture, glycerol release \\
\hline Notes & All patients had hyper triglyceridaemia. Variance for change in weight with interventions not reported \\
& therefore results reported narratively only. \\
\hline Allocation concealment & B - Unclear \\
\hline
\end{tabular}

\begin{tabular}{|c|c|}
\hline Study & Wood 1988 \\
\hline Methods & $\begin{array}{l}\text { DESIGN: Parallel; Randomisation method by envelopes } \\
\text { BLINDING: } \\
\text { patients - not stated } \\
\text { caregivers - not stated } \\
\text { outcome assessors - unclear } \\
\text { DURATION OF INTERVENTION: } 52 \text { weeks } \\
\text { DROPOUTS: } 15 \% \\
\text { Analysis by treatment received }\end{array}$ \\
\hline Participants & $\begin{array}{l}\text { COUNTRY: USA } \\
\text { n: } 131 \\
\text { AGE: N=44.6 years } \\
\text { MALES=all } \\
\text { WEIGHT ENTRY CRITERIA: } 120-160 \% \text { of ideal body weight } \\
\text { EXCLUSION CRITERIA: smokers, consumed more than four alcoholic drinks per day, taking medications } \\
\text { affecting blood pressure or lipids, were not expected to remain living in the local area for } 12 \text { months }\end{array}$ \\
\hline Interventions & $\begin{array}{l}\text { EXERCISE INTERVENTION ( } \mathrm{n}=47) \text { : jogging } 60-80 \% \text { of maximum heart rate for } 40 \text { to } 50 \text { minutes at } \\
\text { least } 3 \text { days a week } \\
\text { DIET INTERVENTION ( } \mathrm{n}=42) \text { : low fat diet } \\
\text { CONTROL ( } \mathrm{n}=42 \text { ): waiting list } \\
\text { FOLLOW-UP: } 52 \text { weeks }\end{array}$ \\
\hline Outcomes & $\begin{array}{l}\text { BODY MEASURES: weight loss }(\mathrm{kg}) \\
\text { OTHER: serum cholesterol and triglycerides, LDL and HDL }\end{array}$ \\
\hline \multicolumn{2}{|l|}{ Notes } \\
\hline Allocation concealment & B - Unclear \\
\hline
\end{tabular}

\begin{tabular}{ll} 
Study & Wood 1991 \\
\hline Methods & DESIGN: Factorial; Randomisation method not stated \\
& BLINDING: \\
\hline Exercise for overwaight or obesity (Review)
\end{tabular}


patients - not stated

caregivers - not stated

outcome assessors - not stated

DURATION OF INTERVENTION: 52 weeks

DROPOUTS: $12.5 \%$

Analysis by treatment received

\begin{tabular}{|c|c|}
\hline Participants & $\begin{array}{l}\text { COUNTRY: USA } \\
\text { n: } 231 \\
\text { AGE: } 25-49 \text { years } \\
\text { MALES }=50 \% \\
\text { WEIGHT ENTRY CRITERIA: } 120-150 \% \text { of ideal body weight } \\
\text { EXCLUSION CRITERIA: smokers, non sedentary, consumed four or more alcoholic drinks per day, poor } \\
\text { physical health, taking medications known to affect blood pressure or lipid metabolism, pregnancy, lactation, } \\
\text { use of oral contraceptives, blood pressure over } 160 / 95 \text { at rest, plasma total cholesterol above } 6.72 \text { mmol per } \\
\text { liter, plasma triglycerides above } 5.65 \text { mmol per liter }\end{array}$ \\
\hline Interventions & $\begin{array}{l}\text { INTERVENTION } 1 \text { ( } \mathrm{n}=81) \text { : brisk walking / jogging for } 40 \text { to } 50 \text { minutes at least } 3 \text { days a week + low fat / } \\
\text { low calorie diet } \\
\text { INTERVENTION } 2 \text { ( } \mathrm{n}=71) \text { : low calorie, low fat diet } \\
\text { CONTROL ( }=79) \text { : waiting list } \\
\text { FOLLOW-UP: } 52 \text { weeks }\end{array}$ \\
\hline Outcomes & $\begin{array}{l}\text { BODY MEASURES: weight loss }(\mathrm{kg}) \\
\text { OTHER: serum cholesterol and triglycerides, LDL and HDL, blood pressure }\end{array}$ \\
\hline \multicolumn{2}{|l|}{ Notes } \\
\hline Allocation concealment & B - Unclear \\
\hline
\end{tabular}

\section{Characteristics of excluded studies}

\begin{tabular}{ll} 
Study & Reason for exclusion \\
\hline Ades 2003 & Participants not overweight or obese \\
\hline Aiello 2004 & No weight loss data for controls \\
\hline Aldred 1995 & Participants not overweight or obese \\
\hline Asikainen 2002 & Participants not overweight or obese \\
\hline Blumenthal 2000 & Loss to follow-up of greater than 15\% \\
\hline Cox 2003 & Loss to follow-up of greater than 15\% \\
\hline Cuff 2003 & Initial sample size not specified - only the number who completed the study \\
\hline Donnelly 2003 & Loss to follow-up of greater than 15\% \\
\hline Dunn 1999 & Loss to follow-up of greater than 15\% \\
\hline Dzator 2004 & Loss to follow-up of greater than 15\% \\
\hline Esposito 2003 & Loss to follow-up of greater than 15\% \\
\hline Esposito 2004 & Diet + exercise versus no treatment control \\
\hline Figueroa 2003 & Participants not all overweight or obese \\
\hline Fogelholm 2001 & Weight maintenance study \\
\hline Grant 2004 & Loss to follow-up of greater than 15\% \\
\hline Exercise for overweight or obesity (Review) \\
Copyright 2007 The Cochrane Collaboration. Published by John Wiley \& Sons, Ltd
\end{tabular}


A D D I T I O N A L T A B L E S

Table 01. Search Strategy

\section{Search terms}

The following Medline search strategy was used and adapted for use with the other databases.

NOTES: unless stated otherwise, search terms are free text terms; MeSH: Medical subject heading (Medline medical index term); an asterisk $\left(^{*}\right)$ stands for 'any character(s)', a question mark stands for 'one or no character'.

OBESITY OR WEIGHT LOSS

1 Obesity/ [MeSH term, all sub trees and subheadings included]

2 Bulimia/ [MeSH term, all subheadings included]

3 Hyperphagia/ [MeSH term, all subheadings included]

4 Anti-Obesity-Agents/ [MeSH term, all subheadings included]

5 Pickwickian syndrome (and) Prader-Willi-syndrome/[MeSH term, all subheadings included]

6 (obes* or adipos* or overweight* or over weight*) [in abstract or title]

7 (overeat* ${ }^{*}$ or overfeed ${ }^{*}$ ) [in abstract or title]

8 (binge eating disorder* or fat overload syndrom*) [in abstract or title]

9 Weight-gain/ [MeSH term, all subheadings included]

10 Weight-loss/ [MeSH term, all subheadings included]

11 Body-Mass-Index/ [MeSH term]

12 weight gain [in abstract or title]

13 weight cycling [in abstract or title]

14 (weight near (reduc* or loss losing or maint* or decreas* or watch* or diet* or control*)) [in abstract or title]

15 or/1-14

This was combined with the following search strategy:

EXERCISE

1. exercis* OR (physic* activ*) OR exert* OR (physic* fit*) OR sports (text words)

2. walk* or jog* or swim* (text words)

3. (weight lift*) OR (strength train*) OR (resistance train*) OR (circuit weight train*) OR (aerob* train*) (text words)

4. exercise/ [MeSH term, all subheadings and categories included]

5. exertion/ [MeSH term, all subheadings and categories included]

6. physical education/ [MeSH term, all subheadings and categories included]

7. training/ [MeSH term, all subheadings and categories included]

8. physical-fitness/ [MeSH term, all subheadings and categories included]

9. sports/ [MeSH term, all subheadings and categories included]

10. OR/ 1-9

This was combined with the following search strategy:

RANDOMISED CONTROLLED TRIALS

1 RANDOMISED-CONTROLLED-TRIAL in PT

2 "RANDOMISED-CONTROLLED-TRIALS"/ all subheadings

3 "RANDOM-ALLOCATION" in MIME, MJME

4 random* or alloc* or assign*

5 (\#4 in $\mathrm{TI})$ or (\#4 in $\mathrm{AB})$

$6 \# 1$ or $\# 2$ or $\# 3$ or \#5

7 CONTROLLED-CLINICAL-TRIAL in PT

8 CLINICAL-TRIAL in PT

9 explode "CLINICAL-TRIALS"/ all subheadings

10 (CLIN* near TRIAL*)

11 (\#10 in $\mathrm{TI})$ or (\#10 in $\mathrm{AB})$

12 "CROSS-OVER-STUDIES" in MIME, MJME

13 cross-over near (stud* or trial* or design*)

Exercise for overweight or obesity (Review)

Copyright @ 2007 The Cochrane Collaboration. Published by John Wiley \& Sons, Ltd 


\section{Table 01. Search Strategy (Continued)}

\section{Search terms}

14 crossover near (stud* or trial* or design*)

$15 \# 7$ or \#8 or \#9 or \#11 or \#12 or \#13 or 14

16 "DOUBLE-BLIND-METHOD” in MIME, MJME

17 "SINGLE-BLIND-METHOD” in MIME, MJME

18 (singl* or doubl* or trebl* or tripl*) near (blind* or mask*)

19 (\#18 in $\mathrm{TI})$ or $(\# 18$ in $\mathrm{AB})$

$20 \# 16$ or \#17 or \#19

21 "PLACEBOS"/ all subheadings

22 placebo* in TI

23 placebo* in $\mathrm{AB}$

$24 \# 21$ or \#22 or \#23

25 explode "RESEARCH-DESIGN"/ all subheadings

26 TG=COMPARATIVE-STUDY

27 explode "EVALUATION-STUDIES"/ all subheadings

28 "FOLLOW-UP-STUDIES" in MIME, MJME

29 "PROSPECTIVE-STUDIES" in MIME, MJME

30 control* $^{*}$ or prospectiv* or volunteer*

$31(\# 30$ in $\mathrm{TI})$ or $(\# 30$ in $\mathrm{AB})$

$32 \# 25$ or $\# 26$ or $\# 27$ or $\# 28$ or $\# 29$ or \#31

33 \#6 or \#15 or \#20 or \#24 or \#32

$34(\mathrm{TG}=\mathrm{ANIMAL})$ not $((\mathrm{TG}=\mathrm{HUMAN})$ and $(\mathrm{TG}=\mathrm{ANIMAL}))$

$35 \# 33$ not \#34

This was combined with the following search strategy:

SYSTEMATIC REVIEWS AND META-ANALYSES

1 "META-ANALYSIS" in MIME,MJME

2 explode "REVIEW-LITERATURE"/ all subheadings

3 META-ANALYSIS in PT

4 REVIEW in PT

5 REVIEW-ACADEMIC in PT

6 REVIEW-LITERATURE in PT

7 REVIEW-TUTORIAL in PT

8 GUIDELINE in PT

9 PRACTICE-GUIDELINE in PT

$10 \# 1$ or $\# 2$ or $\# 3$ or $\# 4$ or $\# 5$ or $\# 6$ or $\# 7$ or $\# 8$ or $\# 9$

11 REVIEW-OF-REPORTED-CASES in PT

12 REVIEW-MULTICASE in PT

13 LETTER in PT

14 COMMENT in PT

15 EDITORIAL in PT

16 HISTORICAL-ARTICLE in PT

$17 \# 11$ or \#12 or \#13 or \#14 or \#15 or \#16

18 \#10 not \#17

19 ((systematic* or quantitativ* or methodologic*) near (review* or overview*)) in TI,AB

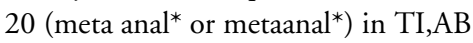

21 (integrativ* research review* ${ }^{*}$ or research integration) in TI,AB

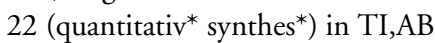

23 (pooling* or (pooled analys*) or (mantel* haenszel*)) in TI,AB

24 (peto* or der simonian* or dersimonian* or fixed effect* or random effect*) in TI,AB

$25 \# 19$ or \#20 or \#21 or \#22 or \#23 or \#24

Exercise for overweight or obesity (Review)

Copyright (c) 2007 The Cochrane Collaboration. Published by John Wiley \& Sons, Ltd 
Table 01. Search Strategy (Continued)

\section{Search terms}

26 \#18 or \#25

$27(\mathrm{TG}=\mathrm{ANIMAL})$ not $((\mathrm{TG}=\mathrm{HUMAN})$ and $(\mathrm{TG}=\mathrm{ANIMAL}))$

28 \#26 not \#27 


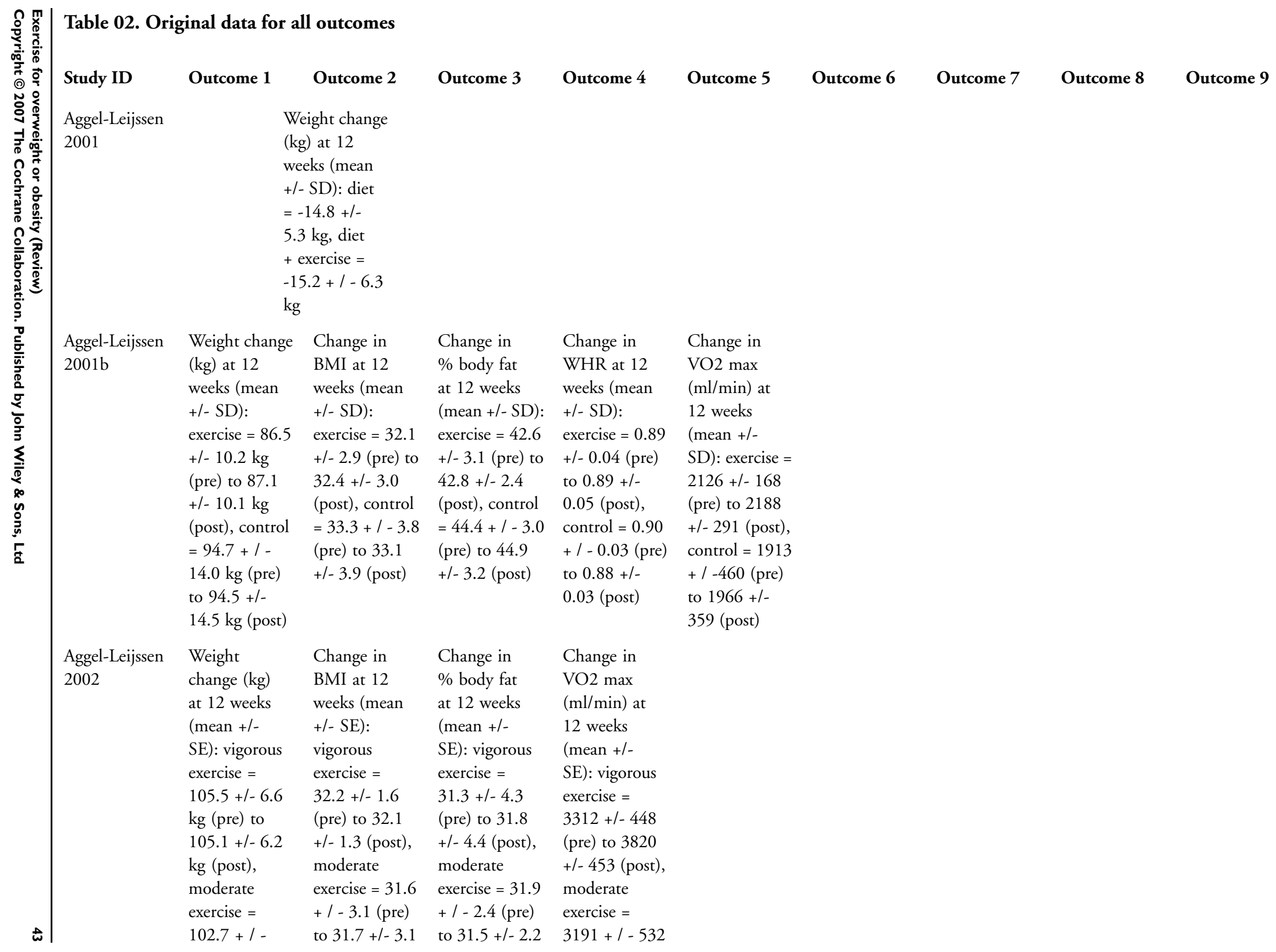




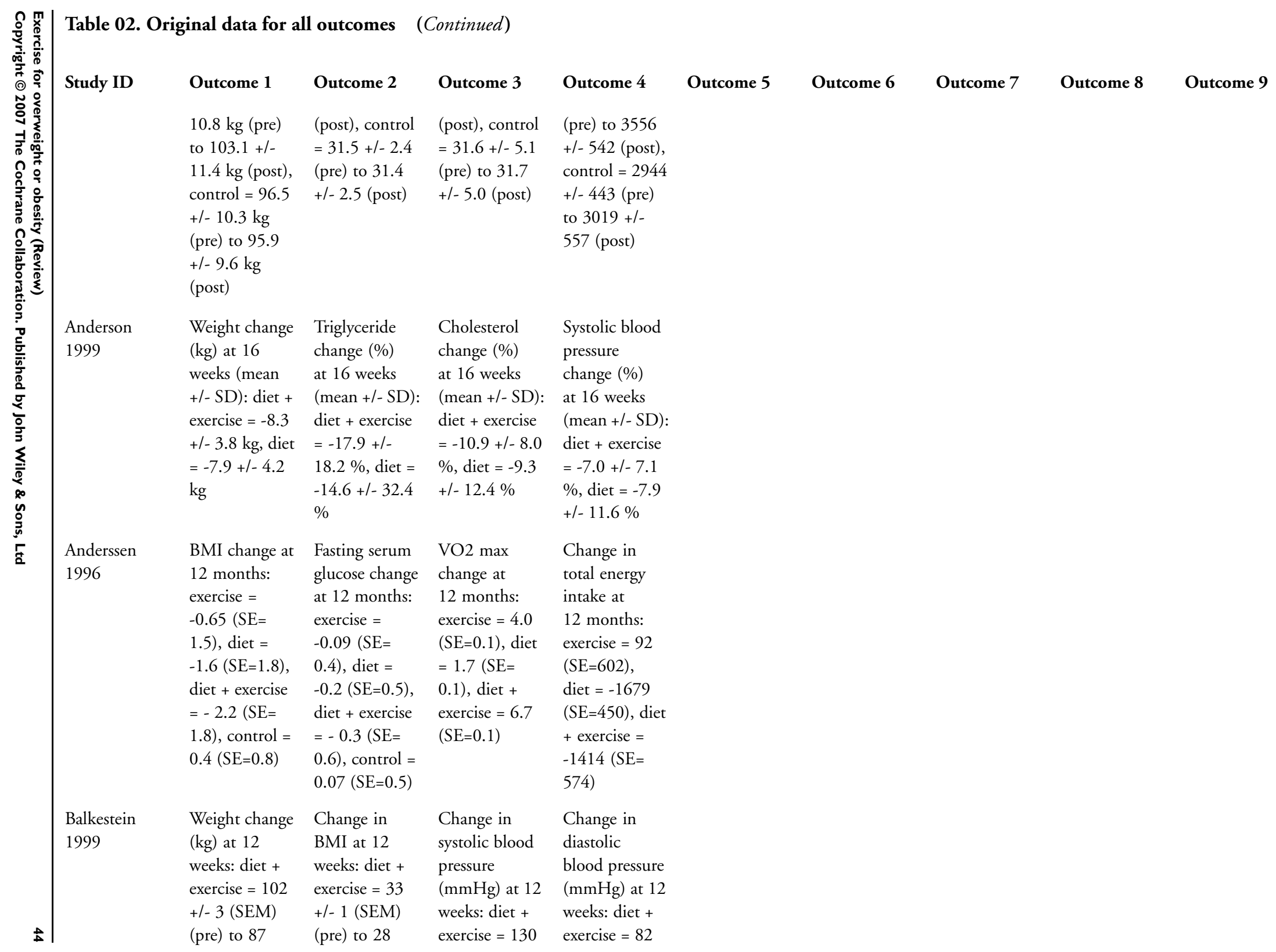




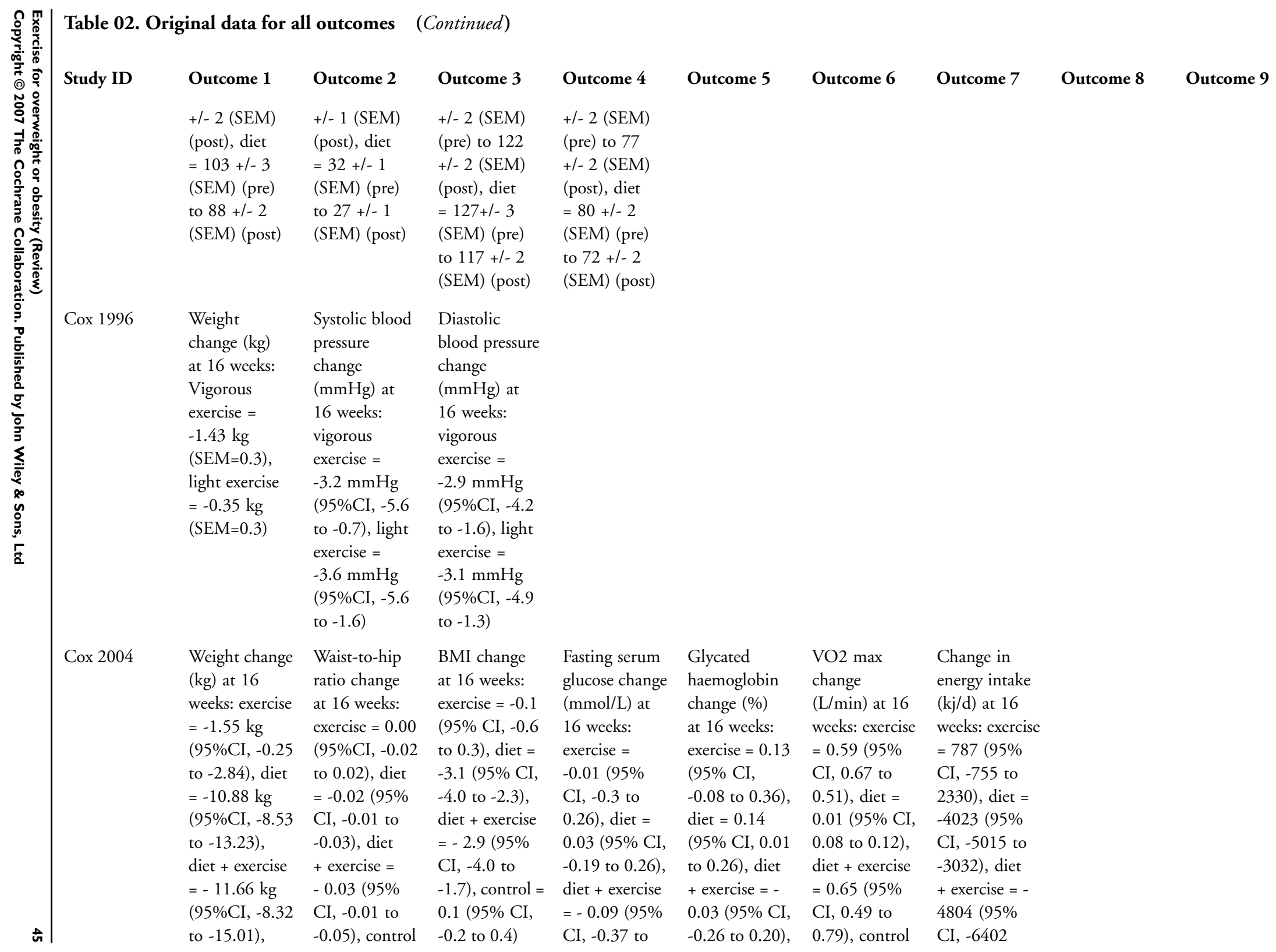




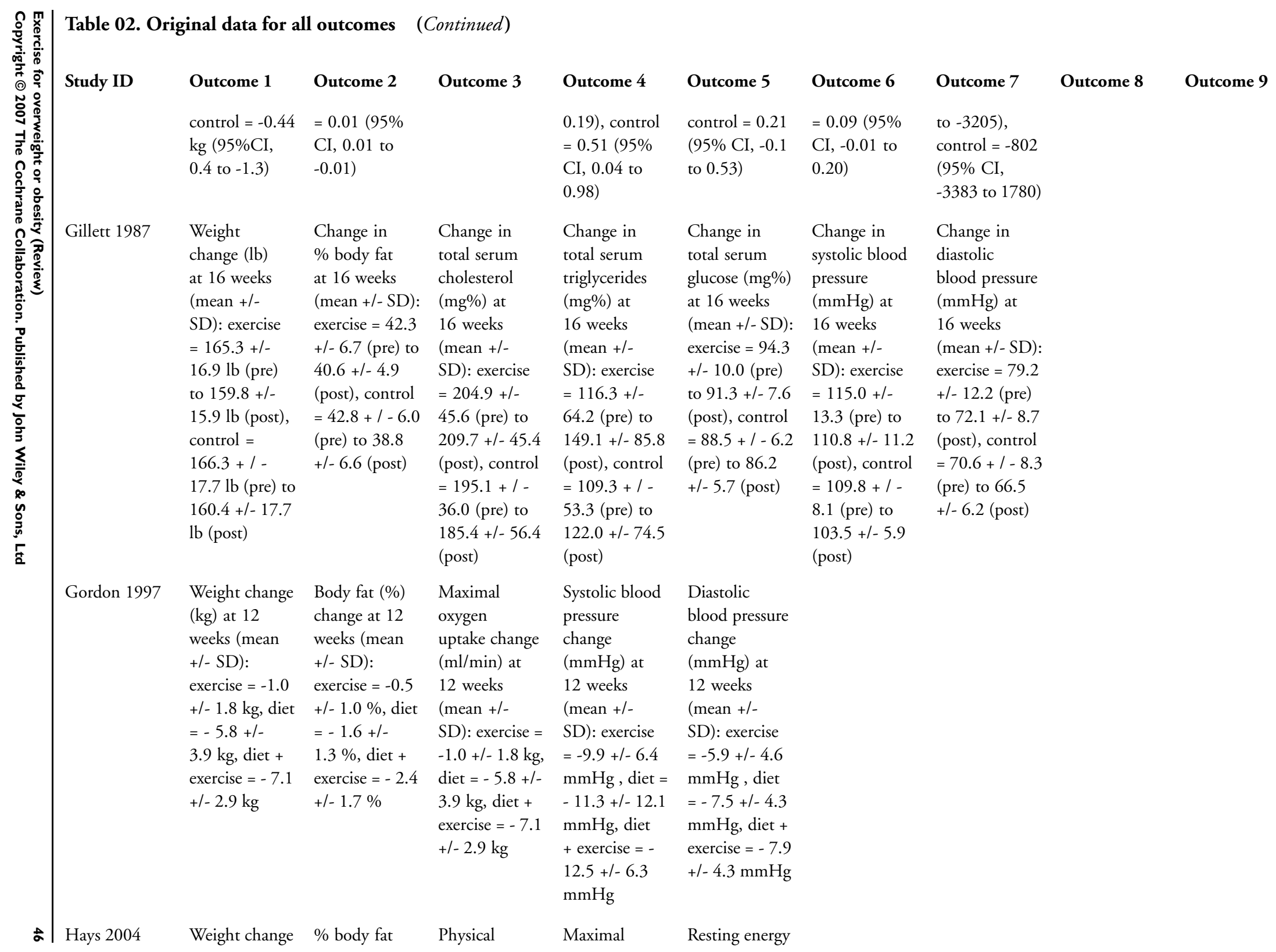




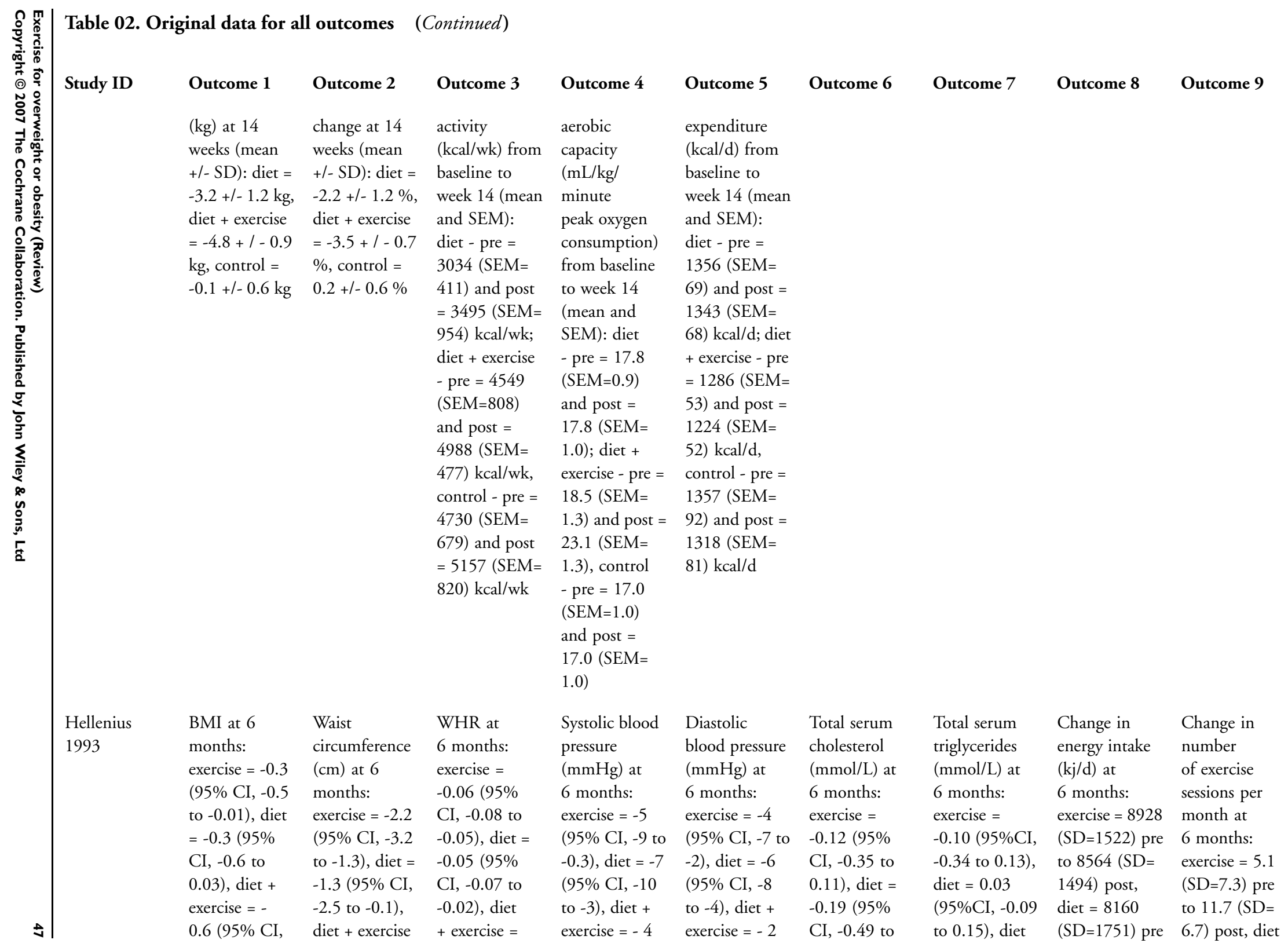




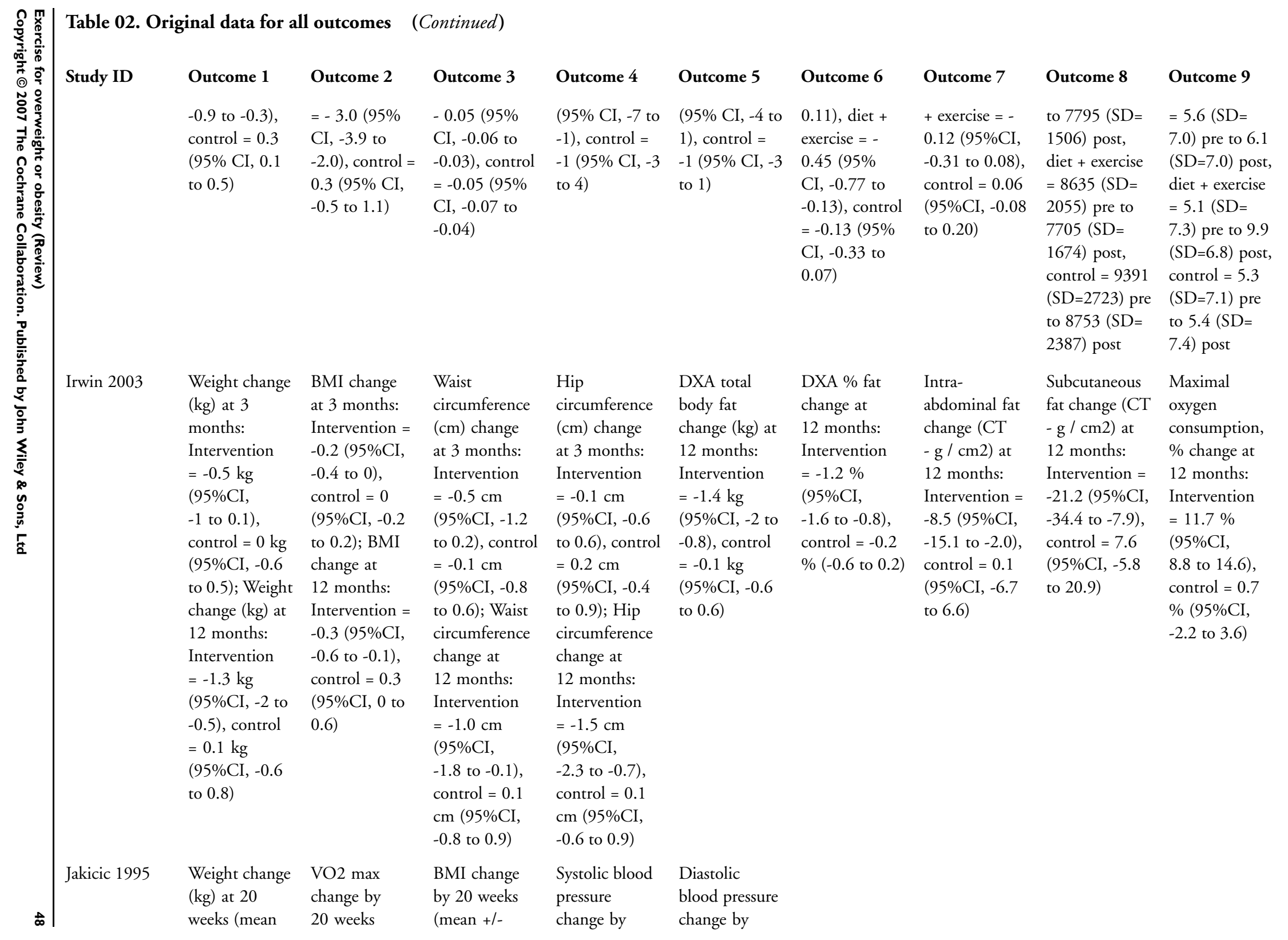


Table 02. Original data for all outcomes (Continued)

\begin{tabular}{|c|c|c|c|c|c|c|}
\hline \multirow[t]{2}{*}{ Study ID } & Outcome 1 & Outcome 2 & Outcome 3 & Outcome 4 & Outcome 5 & Outcome 6 \\
\hline & $\begin{array}{l}+/-\mathrm{SD}): \\
\text { Vigorous } \\
\text { exercise }=-6.4 \\
+/-4.5 \mathrm{~kg}, \\
\text { light exercise = } \\
-8.9+/-5.3 \mathrm{~kg}\end{array}$ & $\begin{array}{l}\text { (mean +/- } \\
\mathrm{SD}) \text { : Vigorous } \\
\text { exercise }= \\
1842.2+/ \text { - } \\
412.5 \mathrm{ml} / \mathrm{min} \\
\text { pre to } 1944.9 \\
+/-337.3 \\
\mathrm{ml} / \mathrm{min} \text { post, } \\
\text { light exercise } \\
=2030.9+/- \\
466.4 \mathrm{ml} / \mathrm{min} \\
\mathrm{pre} \text { to } 2132.2 \\
+/-401.9 \\
\mathrm{ml} / \mathrm{min} \text { post }\end{array}$ & $\begin{array}{l}\text { SD): } \text { Vigorous } \\
\text { exercise }=33.7 \\
+/-4.8 \text { pre } \\
\text { to } 31.3+/- \\
5.0 \text { post, light } \\
\text { exercise }=34.2 \\
+/-3.7 \text { pre to } \\
30.9+/-3.8 \\
\text { post }\end{array}$ & $\begin{array}{l}20 \text { weeks } \\
\text { (mean +/- } \\
\text { SD): Vigorous } \\
\text { exercise = } \\
117.9+/-14.9 \\
\text { mmHg pre to } \\
114.0+/-16.0 \\
\text { mmHg post, } \\
\text { light exercise = } \\
117.0+/-10.5 \\
\text { mmHg pre to } \\
114.3+/-10.8 \\
\text { mmHg post }\end{array}$ & $\begin{array}{l}20 \text { weeks } \\
\text { (mean }+/- \\
\text { SD): Vigorous } \\
\text { exercise }= \\
80.0+/-10.1 \\
\text { mmHg pre to } \\
75.9+/-9.3 \\
\mathrm{mmHg} \text { post, } \\
\text { light exercise } \\
=80.6+/-7.0 \\
\mathrm{mmHg} \text { pre to } \\
75.4+/-8.4 \\
\mathrm{mmHg} \text { post }\end{array}$ & \\
\hline Jakicic 2003 & $\begin{array}{l}\text { Weight change } \\
(\mathrm{kg}) \text { at } 12 \\
\text { months (mean } \\
+/-\mathrm{SD}) \text { : } \\
\text { Vigorous } \\
\text { intensity, } \\
\text { high duration } \\
\text { exercise = } \\
-8.9+/-7.3 \\
\mathrm{~kg}, \text { Moderate } \\
\text { intensity, } \\
\text { high duration } \\
\text { exercise = } \\
-8.2+/-7.6 \\
\mathrm{~kg}, \text { Moderate } \\
\text { intensity, } \\
\text { moderate } \\
\text { duration } \\
\text { exercise = } \\
-6.3+/-5.6 \\
\text { kg, Vigorous }\end{array}$ & $\begin{array}{l}\text { BMI change } \\
\text { from baseline } \\
\text { to } 12 \text { months } \\
\text { (mean +/- } \\
\text { SD): Vigorous } \\
\text { intensity, } \\
\text { high duration } \\
\text { exercise = } \\
32.9+/-3.9 \\
\text { (pre) to } 29.5 \\
+/-4.8 \text { (post), } \\
\text { Moderate } \\
\text { intensity, } \\
\text { high duration } \\
\text { exercise = } \\
32.3+/-3.9 \\
\text { (pre) to } 29.2 \\
+/-4.8 \text { (post), } \\
\text { Moderate } \\
\text { intensity, } \\
\text { moderate }\end{array}$ & $\begin{array}{l}\text { Change in } \\
\text { leisure-time } \\
\text { physical } \\
\text { activity } \\
\text { (min/week) } \\
\text { from baseline } \\
\text { to } 12 \text { months } \\
\text { (mean +/- } \\
\text { SD): Vigorous } \\
\text { intensity, } \\
\text { high duration } \\
\text { exercise = } \\
134.3+/- \\
288.8 \text { (pre) } \\
\text { to } 175.7+/- \\
170.3 \text { (post), } \\
\text { Moderate } \\
\text { intensity, } \\
\text { high duration } \\
\text { exercise = } \\
160.6+/-\end{array}$ & $\begin{array}{l}\text { Change in } \\
\text { energy intake } \\
\text { (kcal/day) } \\
\text { from baseline } \\
\text { to } 12 \text { months } \\
\text { (mean +/- } \\
\text { SD): Vigorous } \\
\text { intensity, } \\
\text { high duration } \\
\text { exercise = } \\
2099+/-796 \\
\text { (pre) to } 1471 \\
+/-532 \text { (post), } \\
\text { Moderate } \\
\text { intensity, } \\
\text { high duration } \\
\text { exercise = } \\
2116+/-981 \\
\text { (pre) to } 1557 \\
+/-531 \text { (post), } \\
\text { Moderate }\end{array}$ & $\begin{array}{l}\text { Change in car- } \\
\text { diorespiratory } \\
\text { fitness ( } \mathrm{mL} / \mathrm{kg} \text { ) } \\
\text { from baseline } \\
\text { to } 12 \text { months } \\
\text { (mean }+/ \text { - } \\
\text { SD): Vigorous } \\
\text { intensity, } \\
\text { high duration } \\
\text { exercise = } \\
20.2+/-2.9 \\
\text { (pre) to } 24.5 \\
+/-4.8 \text { (post), } \\
\text { Moderate } \\
\text { intensity, } \\
\text { high duration } \\
\text { exercise = } \\
19.4+/-3.2 \\
\text { (pre) to } 22.1 \\
+/-4.0 \text { (post), } \\
\text { Moderate }\end{array}$ & $\begin{array}{l}\text { Change in } \\
\text { cardiorespi- } \\
\text { ratory fitness } \\
\text { at } 12 \text { months } \\
\text { (mean +/- } \\
\text { SD): Vigorous } \\
\text { intensity, } \\
\text { high duration } \\
\text { exercise = } 22 \\
+/-19.9 \%, \\
\text { Moderate } \\
\text { intensity, } \\
\text { high duration } \\
\text { exercise = } \\
14.9+/-18.6 \\
\%, \text { Moderate } \\
\text { intensity, } \\
\text { moderate } \\
\text { duration } \\
\text { exercise = } \\
13.5+/-16.9\end{array}$ \\
\hline
\end{tabular}




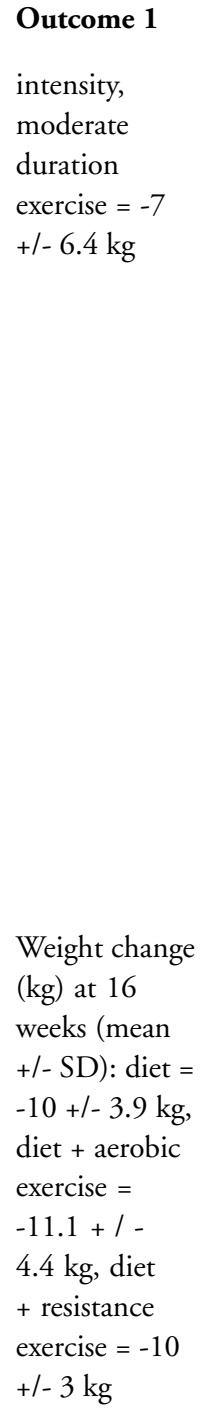

\section{Outcome 2}

duration

exercise $=$

$32.7+/-4.3$

(pre) to 30.3

+/- 4.5 (post),

Vigorous

intensity,

moderate

duration

exercise $=32.7$

$+1-4.6$ (pre) to

$30.2+/-4.6$

(post)

$-3 \mathrm{~kg}$

\section{BMI change}

at 16 weeks

(mean +/-

$-4+/-1.4$,

diet + aerobic

exercise $=-4.2$

+ / - 1.2, diet

+ resistance

$+/-1$
Outcome 3

248.8 (pre)

to $189.9+/$ -

119.0 (post)

Moderate

intensity,

moderate

duration

exercise =

108.3 +/-

221.7 (pre)

to $206.6+/$ -

242.0 (post)

Vigorous

intensity,

moderate

duration

exercise $=$

$115.2+/-$

245.3 (pre)

to $140.1+/$

115.4 (post)

Fasting serum

glucose change

(mmol/L)

at 16 weeks

(mean +/-

SD): $\operatorname{diet}=$

$-0.1+/-0.4$,

diet + aerobic

exercise $=-0.1$

$+1-0.5$, diet

+ resistance

exercise $=-0.1$

$+/-0.4$

\section{Outcome 4}

intensity,

moderate

duration

exercise $=$

$2027+/-743$

(pre) to 1350

+/- 422 (post),

Vigorous

intensity,

moderate

duration

exercise $=2200$

$+/-875$ (pre)

to $1449+/-$

502 (post)

\section{Outcome 5}

intensity,

moderat

duration

exercise $=$

$19.7+/-3.7$

(pre) to 22.2

+/- 4.6 (post),

Vigorous

intensity,

moderate

duration

exercise $=19.7$

$+/-3.1$ (pre) to

$23.3+/-4.5$

(post)

\section{Outcome 6}

$\%$, Vigorous

intensity,

moderate

duration

exercise $=18.9$

+/- $16.9 \%$
Outcome $7 \quad$ Outcome 8

Outcome 9
Serum

triglyceride

change

(mmol/L)

at 16 weeks

(mean +/-

SD): diet $=$

$-0.3+1-1.6$,

diet + aerobic

exercise $=-0.3$

+ / -0.5 , diet

+ resistance

exercise $=-0.4$

$+/-0.8$
Fasting serum

cholesterol

change

( $\mathrm{mmol} / \mathrm{L})$

at 16 weeks

(mean +/-

SD): diet =

$-0.8+/-0.4$

diet + aerobic

exercise $=-0.4$

+ / - 0.6, diet

+ resistance

exercise $=-0.6$ 


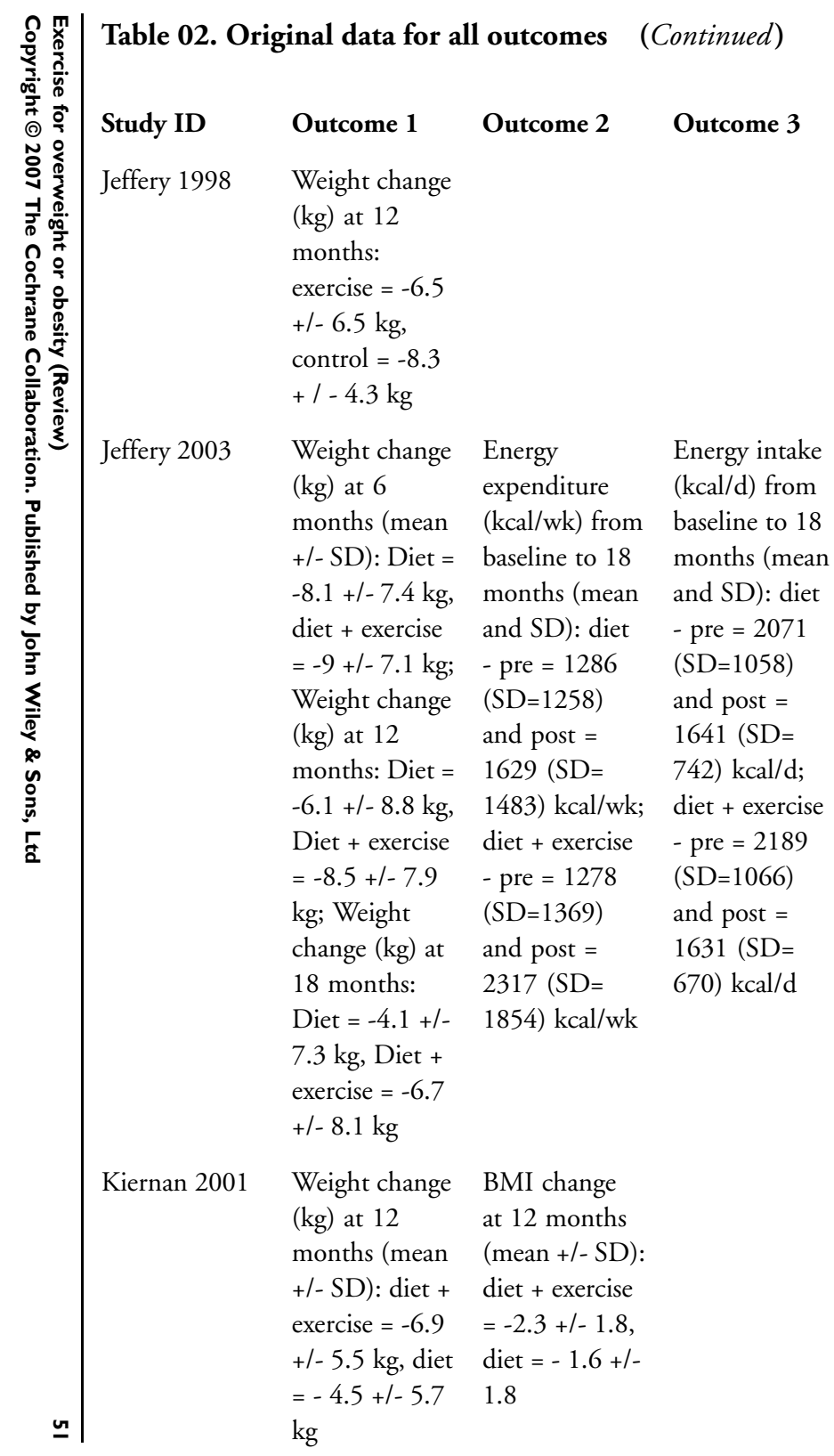




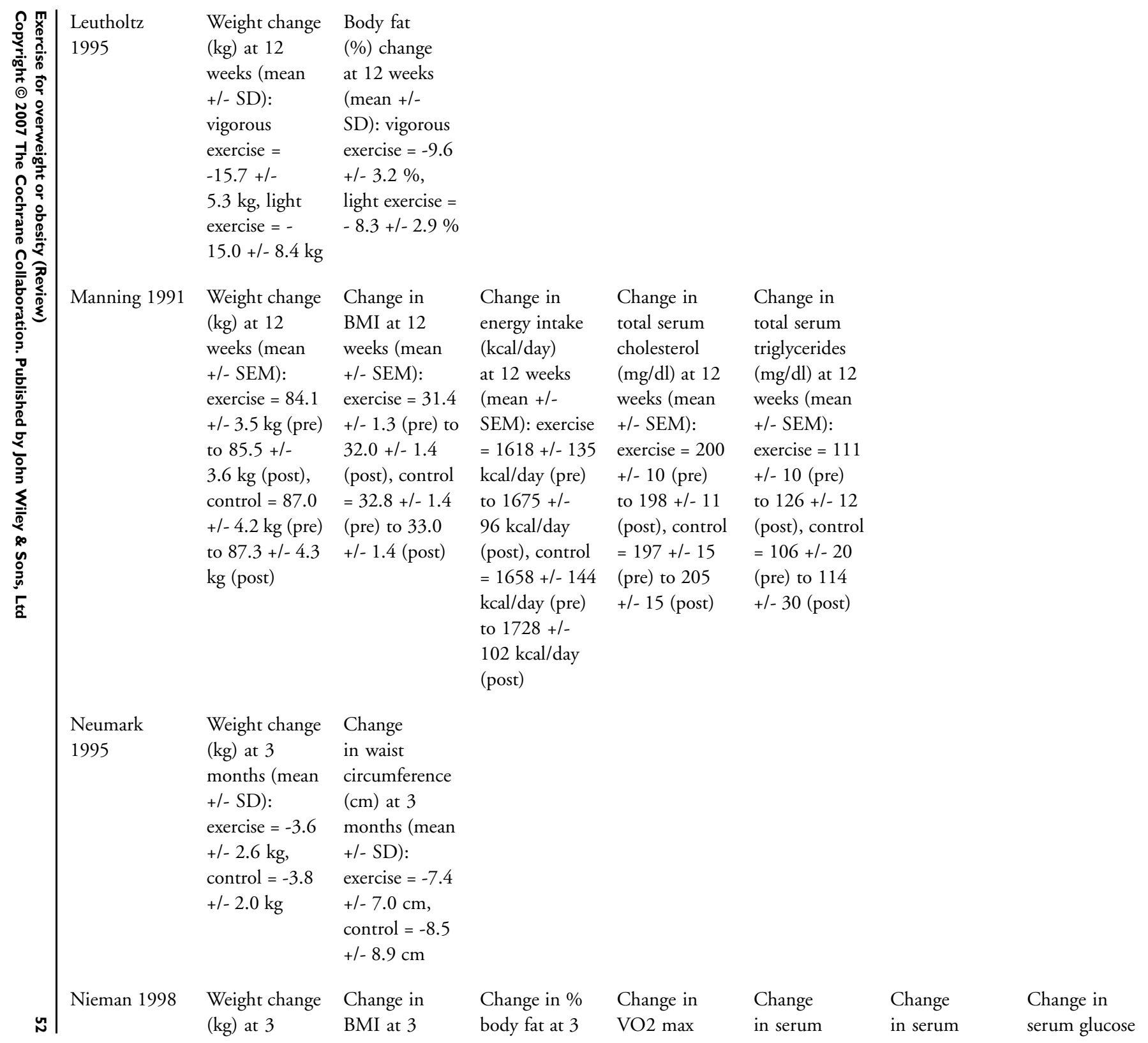




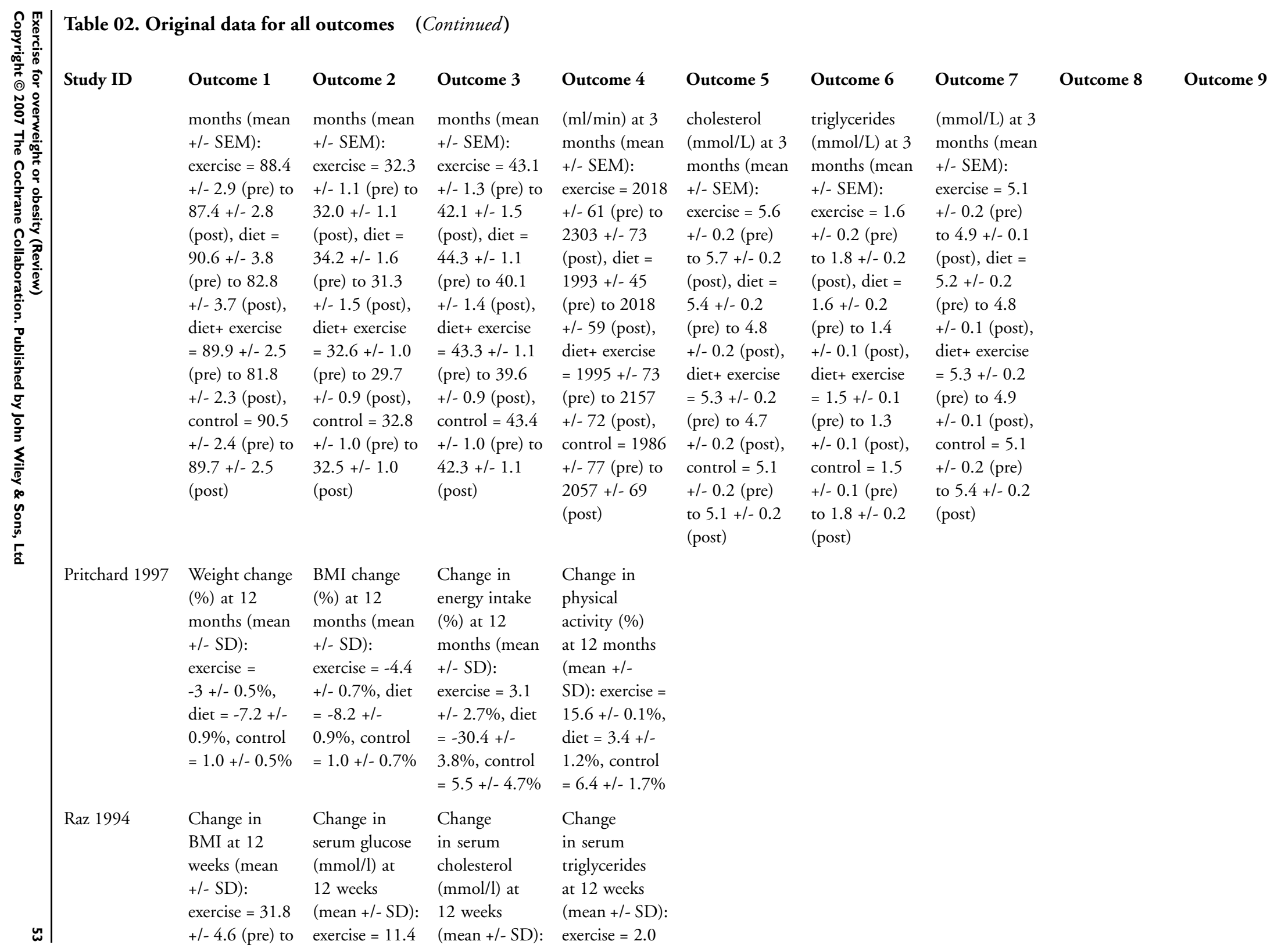




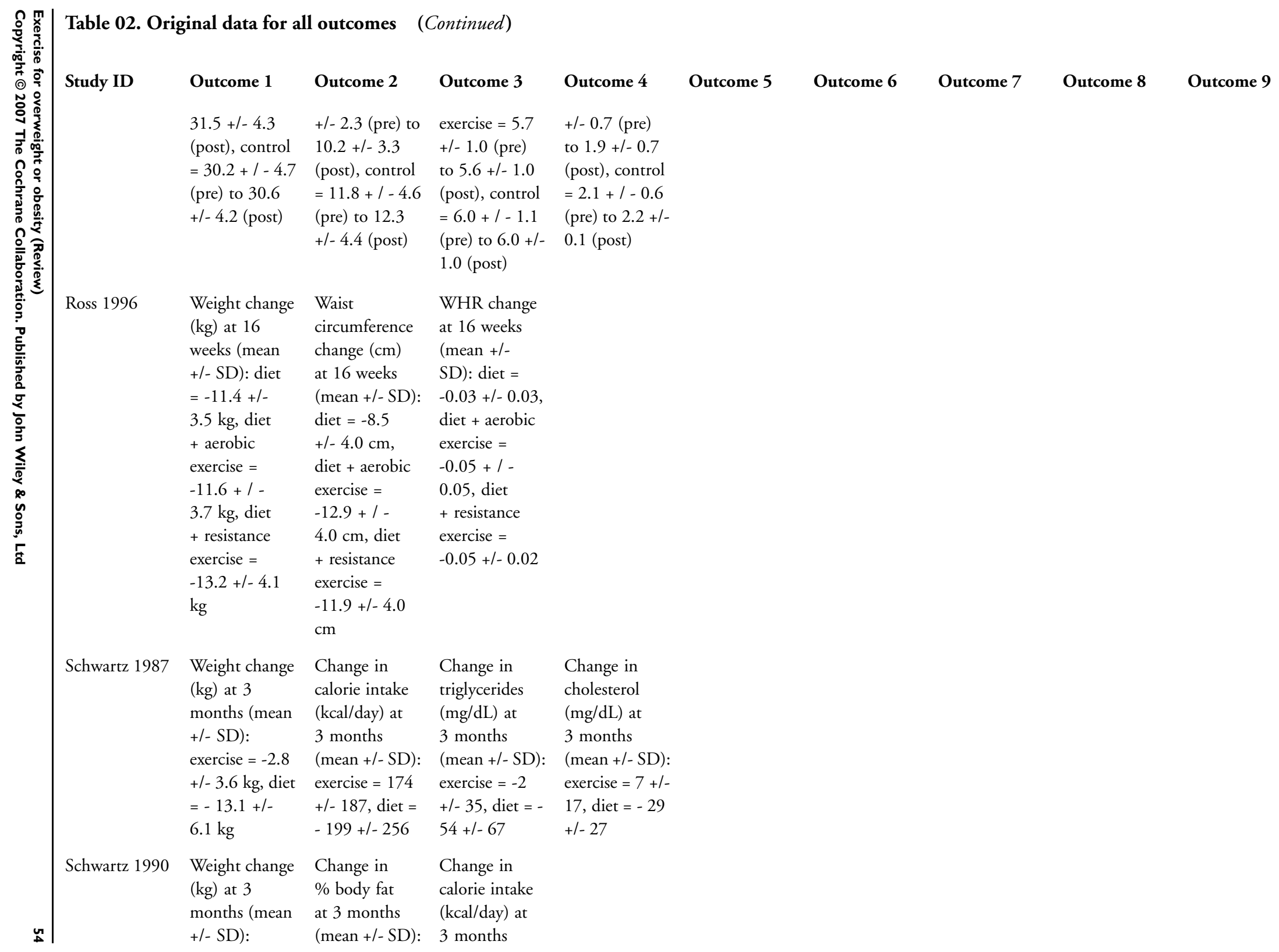




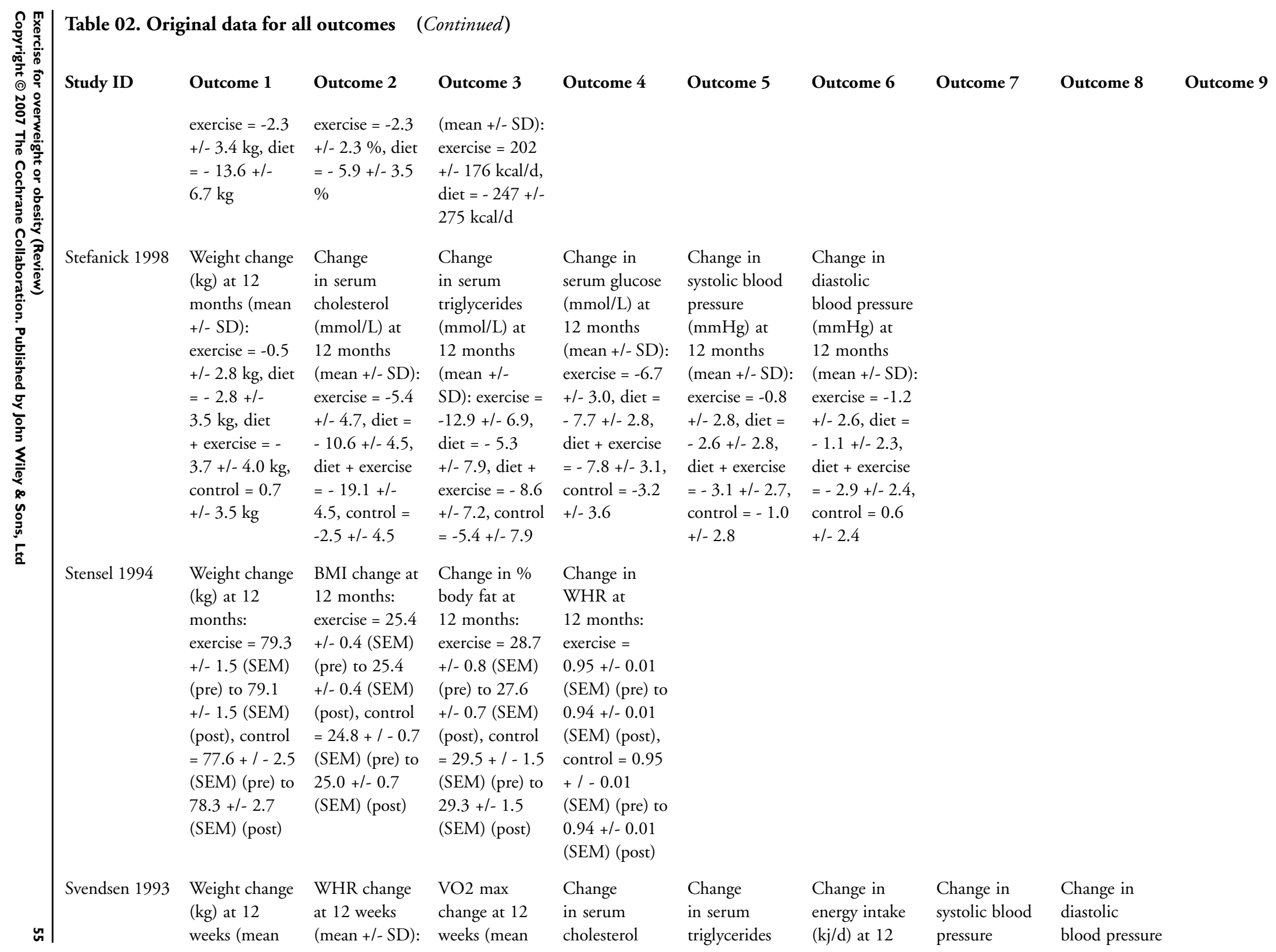




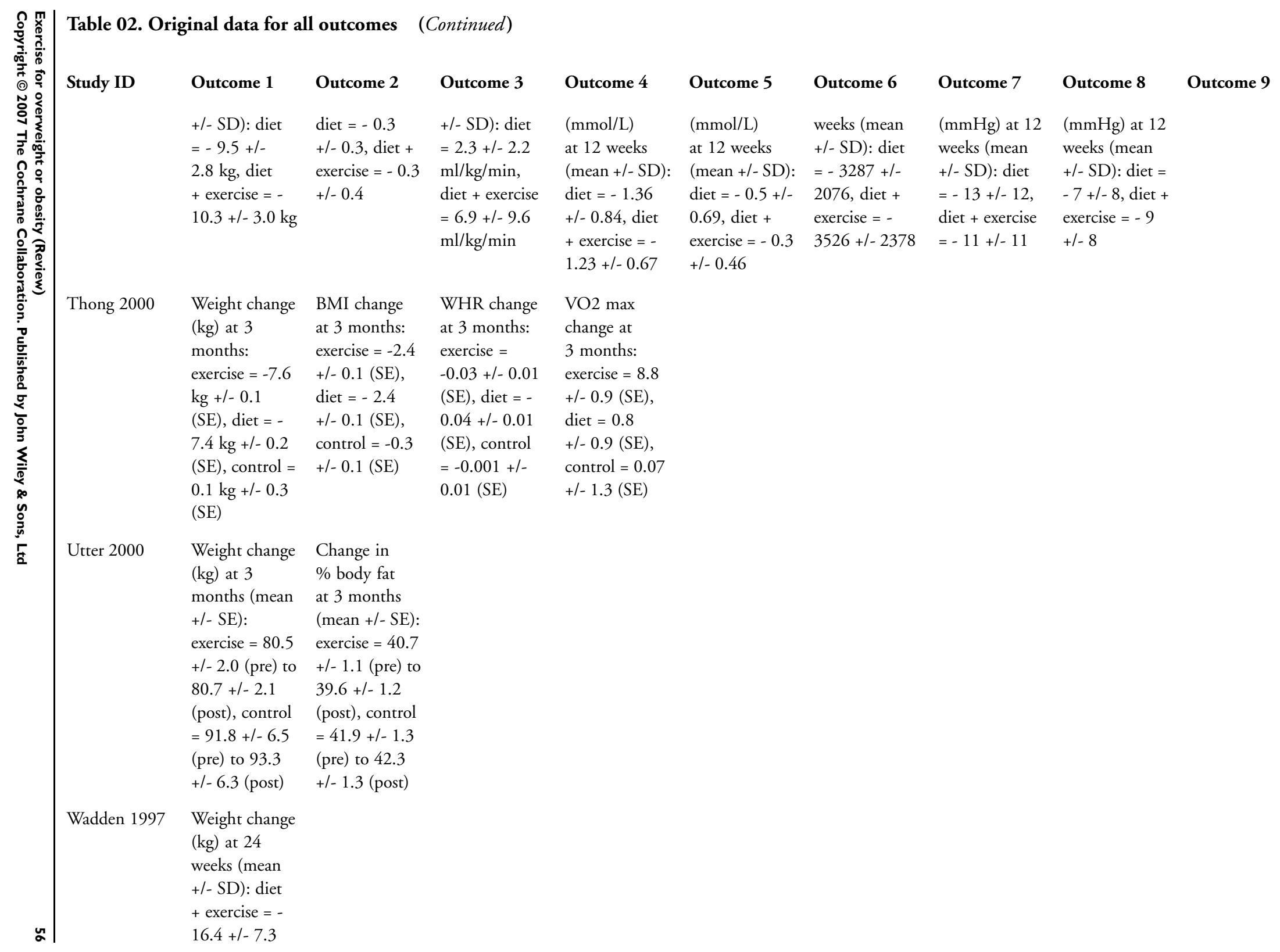




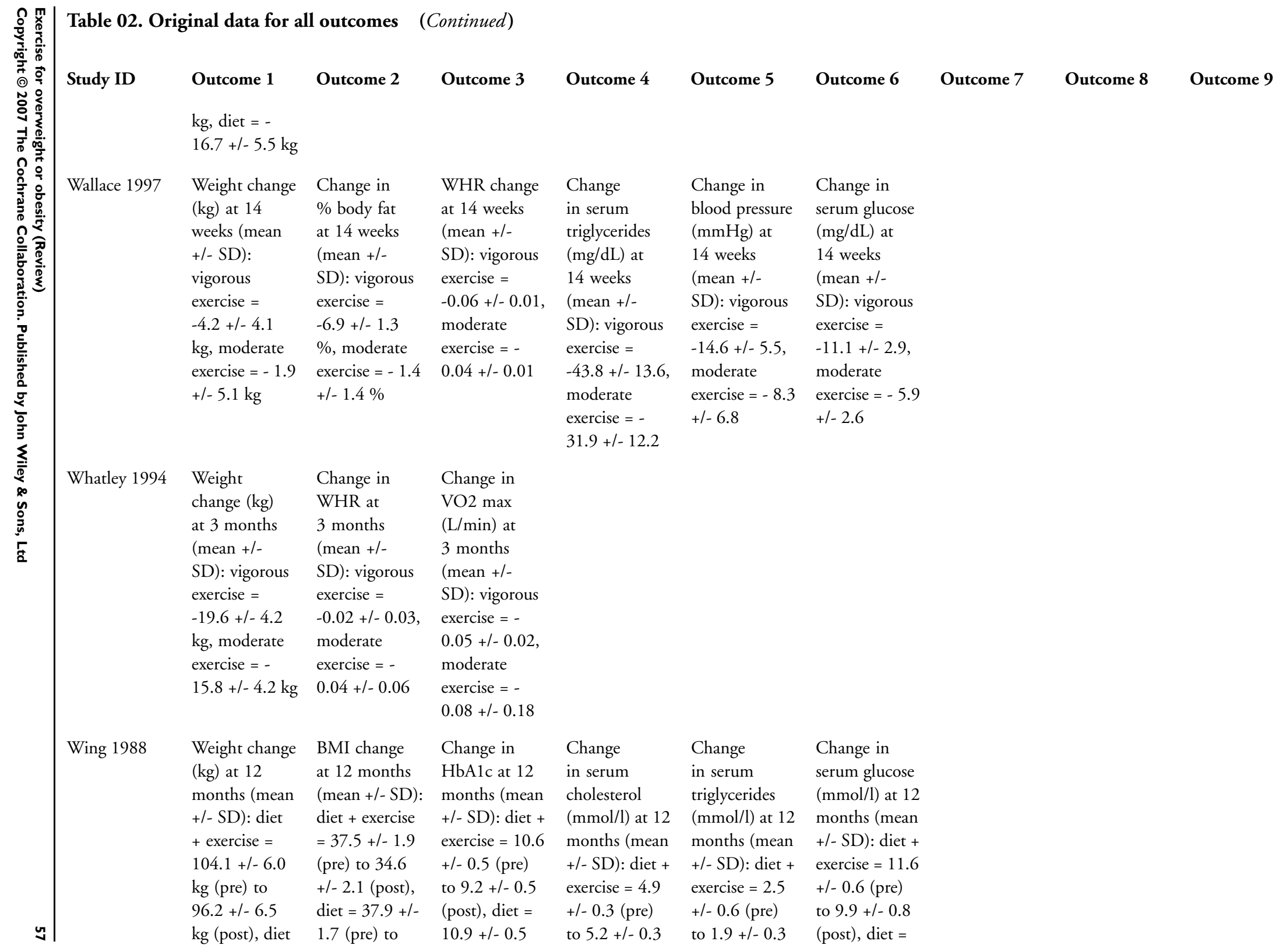




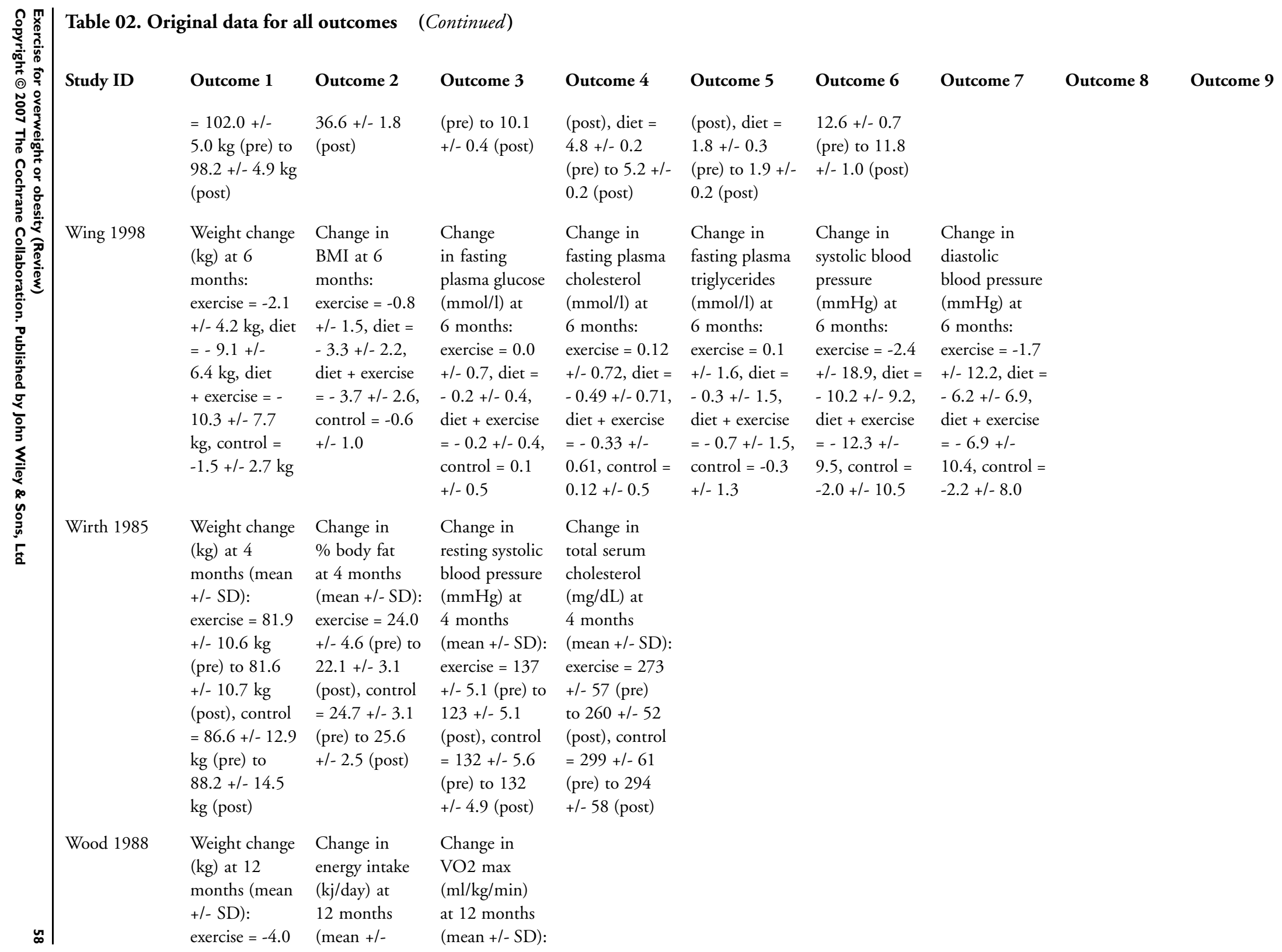




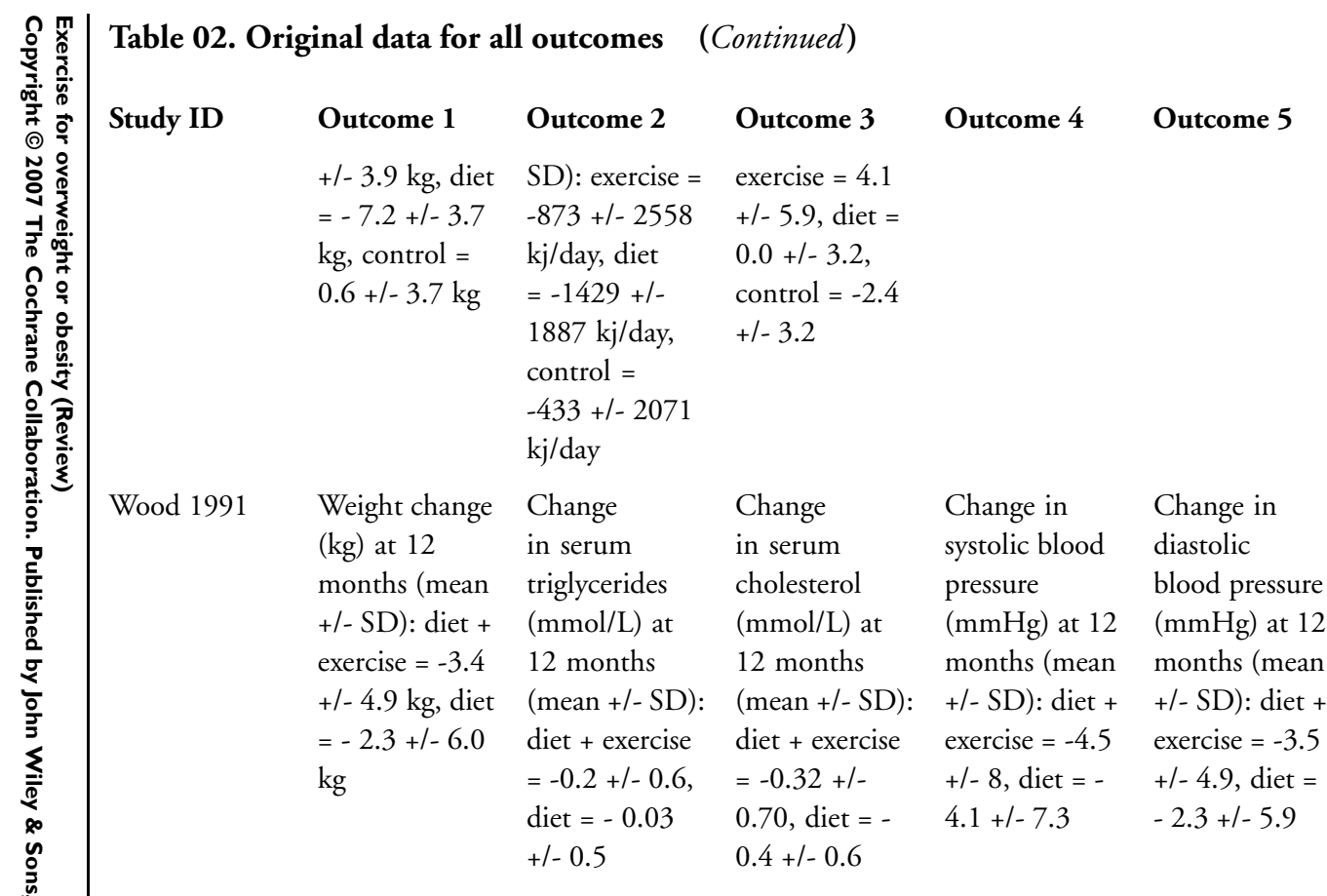

$\mathrm{SD}=$ standard deviation; $\mathrm{SE}=$ standard error; $\mathrm{SEM}=$ standard error of the mean; $\mathrm{CI}=$ confidence interval; $\mathrm{kg}=\mathrm{kilograms}$; $\mathrm{lb}=$ pounds; $\mathrm{BMI}=$ body mass index; WHR=waist-hip ratio; DXA=dual-energy $\mathrm{x}$-ray absorptiometry; $\mathrm{mmHg}=$ millimetres of mercury; kcal=kilocalories; VO2max=maximal oxygen uptake; HDL=high-density lipoprotein; $\mathrm{LDL}=$ low-density lipoprotein; $\mathrm{mmol} / \mathrm{L}=$ millimoles per litre 


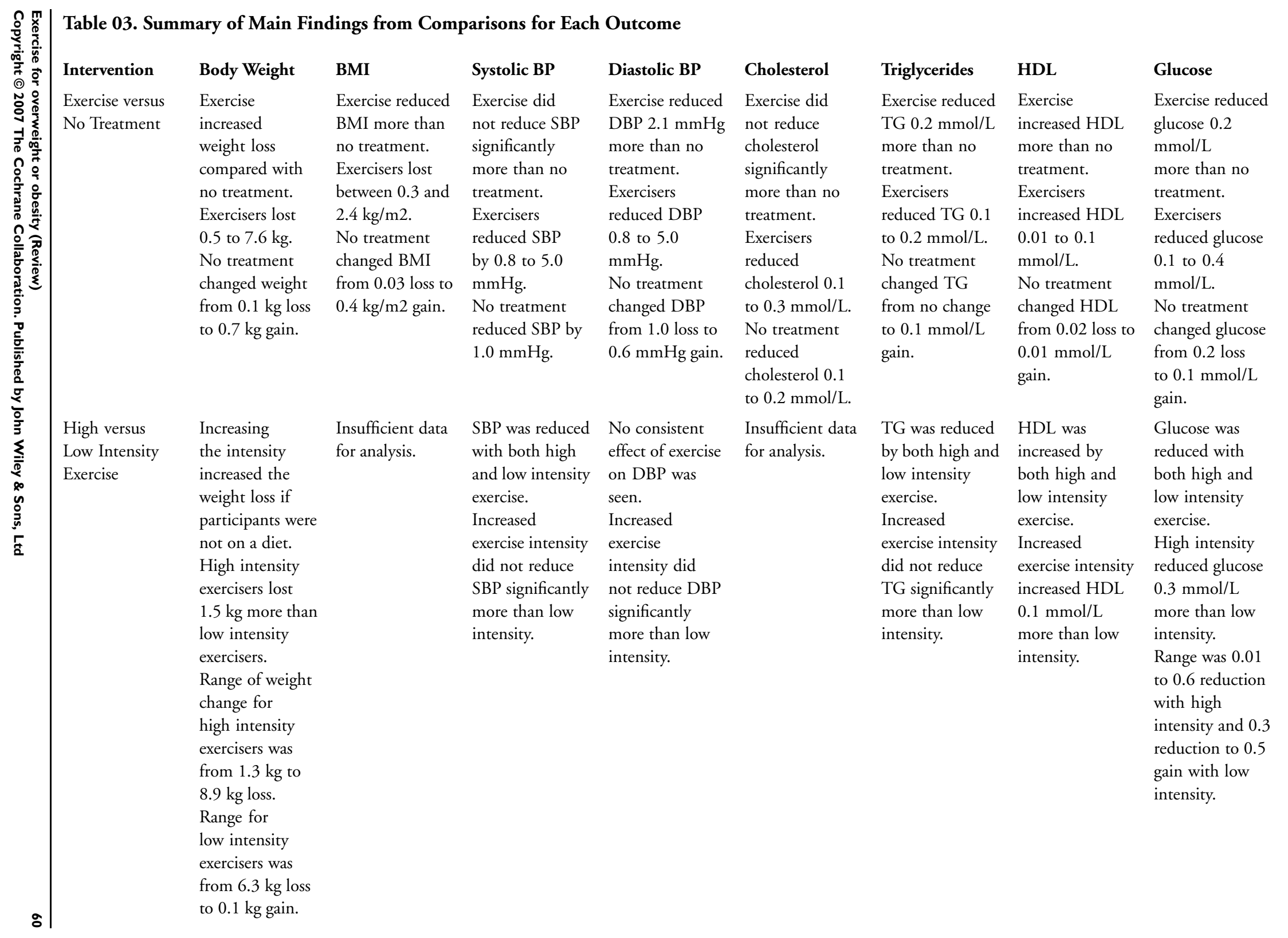




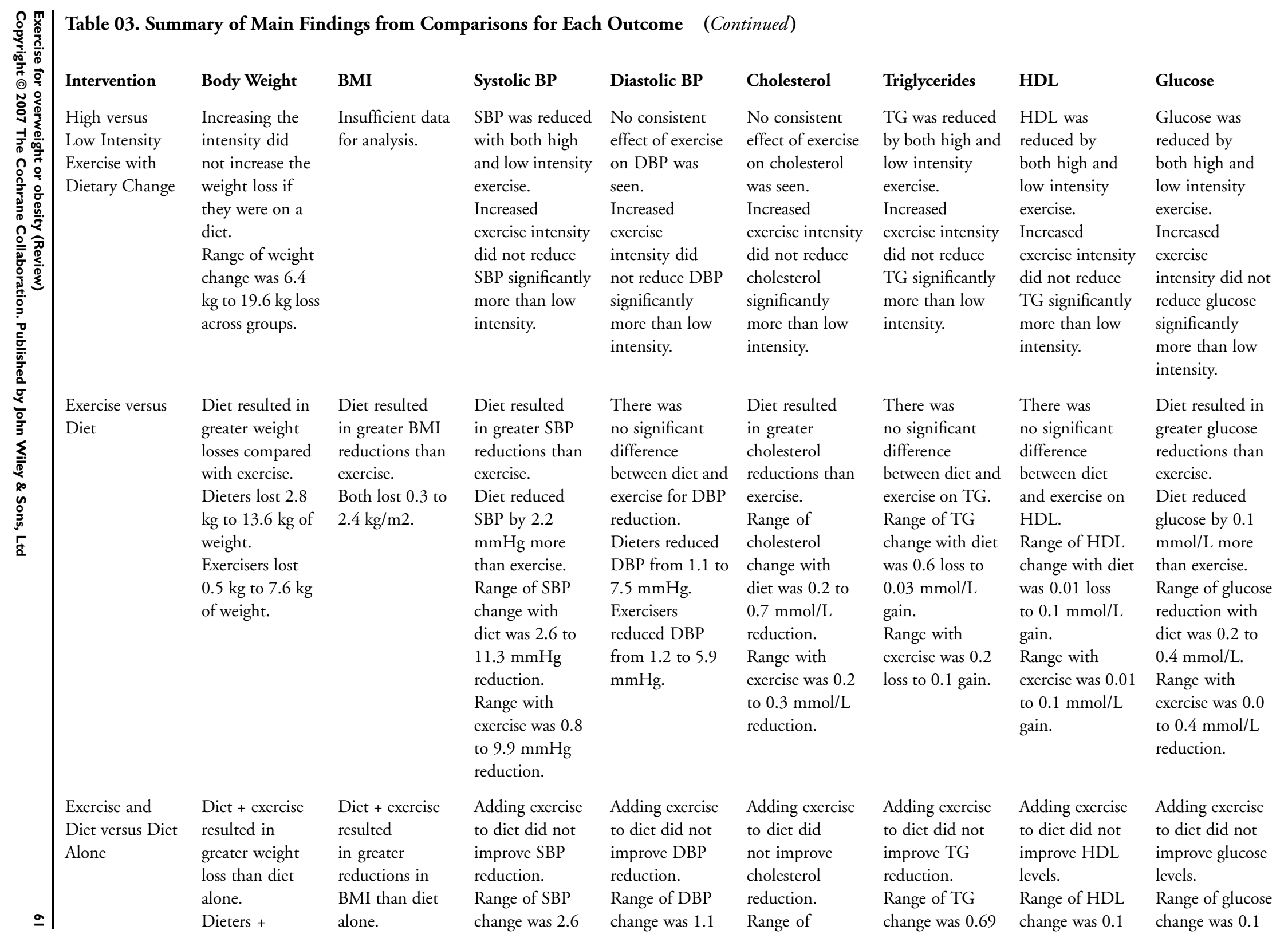




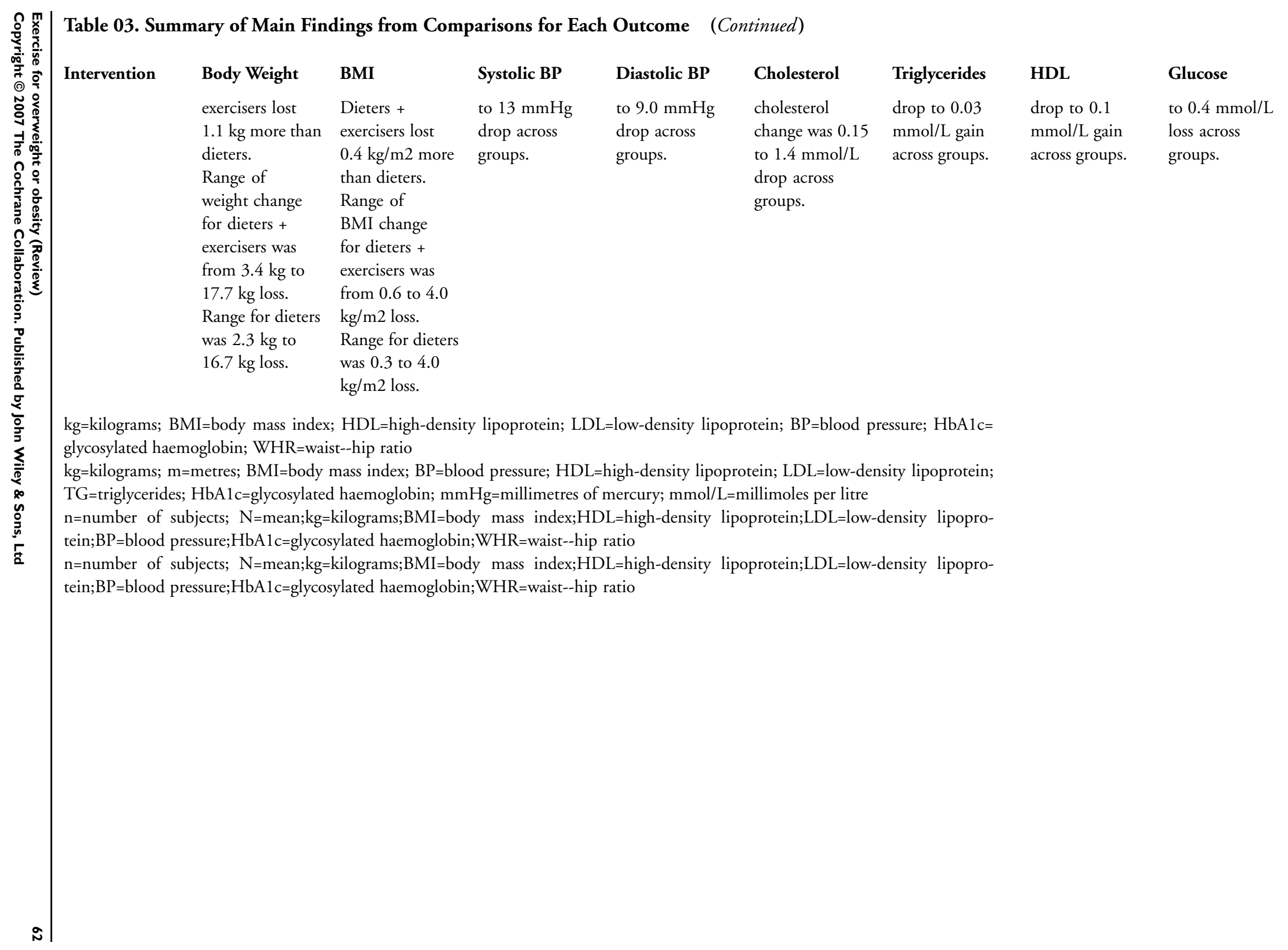




\section{A NALYSES}

\section{Comparison 01. Exercise versus no treatment control}

\begin{tabular}{|c|c|c|c|c|}
\hline Outcome title & $\begin{array}{l}\text { No. of } \\
\text { studies }\end{array}$ & $\begin{array}{c}\text { No. of } \\
\text { participants }\end{array}$ & Statistical method & Effect size \\
\hline 01 Weight change in kilograms & & & Weighted Mean Difference (Fixed) 95\% CI & Totals not selected \\
\hline $\begin{array}{l}02 \text { Change in body mass index } \\
\text { (BMI) }\end{array}$ & & & Weighted Mean Difference (Fixed) 95\% CI & Totals not selected \\
\hline $\begin{array}{l}03 \text { Change in systolic blood } \\
\text { pressure }(\mathrm{mmHg})\end{array}$ & & & Weighted Mean Difference (Fixed) 95\% CI & Totals not selected \\
\hline $\begin{array}{l}04 \text { Change in diastolic blood } \\
\text { pressure }(\mathrm{mmHg})\end{array}$ & 2 & 259 & Weighted Mean Difference (Fixed) 95\% CI & $-2.09[-3.68,-0.51]$ \\
\hline $\begin{array}{l}05 \text { Change in total serum } \\
\text { cholesterol }(\mathrm{mmol} / \mathrm{l})\end{array}$ & 3 & 348 & Weighted Mean Difference (Fixed) 95\% CI & $0.03[-0.09,0.15]$ \\
\hline $\begin{array}{l}06 \text { Change in serum triglycerides } \\
(\mathrm{mmol} / \mathrm{l})\end{array}$ & 3 & 348 & Weighted Mean Difference (Fixed) 95\% CI & $-0.18[-0.31,-0.05]$ \\
\hline $\begin{array}{l}07 \text { Change in serum HDL } \\
(\mathrm{mmol} / \mathrm{l})\end{array}$ & & & Weighted Mean Difference (Fixed) 95\% CI & Totals not selected \\
\hline $\begin{array}{l}08 \text { Change in fasting serum } \\
\text { glucose }(\mathrm{mmol} / \mathrm{l})\end{array}$ & 2 & 273 & Weighted Mean Difference (Fixed) 95\% CI & $-0.17[-0.30,-0.05]$ \\
\hline
\end{tabular}

\section{Comparison 02. Exercise versus diet}

\begin{tabular}{|c|c|c|c|c|}
\hline Outcome title & $\begin{array}{l}\text { No. of } \\
\text { studies }\end{array}$ & $\begin{array}{c}\text { No. of } \\
\text { participants }\end{array}$ & Statistical method & Effect size \\
\hline 01 Weight change in kilograms & & & Weighted Mean Difference (Fixed) 95\% CI & Totals not selected \\
\hline $\begin{array}{l}02 \text { Change in body mass index } \\
\text { (BMI) }\end{array}$ & & & Weighted Mean Difference (Fixed) 95\% CI & Totals not selected \\
\hline $\begin{array}{l}03 \text { Change in systolic blood } \\
\text { pressure }(\mathrm{mmHg})\end{array}$ & 4 & 361 & Weighted Mean Difference (Fixed) 95\% CI & $2.24[0.29,4.20]$ \\
\hline $\begin{array}{l}04 \text { Change in diastolic blood } \\
\text { pressure }(\mathrm{mmHg})\end{array}$ & 4 & 361 & Weighted Mean Difference (Fixed) 95\% CI & $0.87[-0.44,2.18]$ \\
\hline $\begin{array}{l}05 \text { Change in total serum } \\
\text { cholesterol }(\mathrm{mmol} / \mathrm{l})\end{array}$ & & & Weighted Mean Difference (Fixed) 95\% CI & Totals not selected \\
\hline $\begin{array}{l}06 \text { Change in serum triglycerides } \\
(\mathrm{mmol} / \mathrm{l})\end{array}$ & & & Weighted Mean Difference (Fixed) 95\% CI & Totals not selected \\
\hline $\begin{array}{l}07 \text { Change in serum HDL } \\
(\mathrm{mmol} / \mathrm{l})\end{array}$ & & & Weighted Mean Difference (Fixed) 95\% CI & Totals not selected \\
\hline $\begin{array}{l}08 \text { Change in fasting serum } \\
\text { glucose }(\mathrm{mmol} / \mathrm{l})\end{array}$ & 3 & 354 & Weighted Mean Difference (Fixed) 95\% CI & $0.10[-0.00,0.20]$ \\
\hline
\end{tabular}

\section{Comparison 03. Exercise + diet versus diet alone}

\begin{tabular}{|c|c|c|c|c|}
\hline Outcome title & $\begin{array}{l}\text { No. of } \\
\text { studies }\end{array}$ & $\begin{array}{c}\text { No. of } \\
\text { participants }\end{array}$ & Statistical method & Effect size \\
\hline 01 Weight change in kilograms & 33 & 2157 & Weighted Mean Difference (Fixed) 95\% CI & $-1.02[-1.32,-0.72]$ \\
\hline $\begin{array}{l}02 \text { Change in body mass index } \\
\text { (BMI) }\end{array}$ & 5 & 452 & Weighted Mean Difference (Fixed) 95\% CI & $-0.43[-0.71,-0.14]$ \\
\hline $\begin{array}{l}03 \text { Change in systolic blood } \\
\text { pressure }(\mathrm{mmHg})\end{array}$ & 6 & 615 & Weighted Mean Difference (Fixed) 95\% CI & $-0.11[-1.48,1.25]$ \\
\hline
\end{tabular}

Exercise for overweight or obesity (Review) 
04 Change in diastolic blood pressure $(\mathrm{mmHg})$

05 Change in total serum cholesterol $(\mathrm{mmol} / \mathrm{l})$

06 Change in serum triglycerid (mmol/l)

07 Change in serum HDL ( $\mathrm{mmol} / \mathrm{l})$

08 Change in fasting serum glucose $(\mathrm{mmol} / \mathrm{l})$
Weighted Mean Difference (Fixed) 95\% CI Totals not selected

Weighted Mean Difference (Fixed) 95\% CI Totals not selected

6

Weighted Mean Difference (Fixed) 95\% CI

$-0.08[-0.18,0.02]$

Weighted Mean Difference (Fixed) 95\% CI Totals not selected

4

407

Weighted Mean Difference (Fixed) 95\% CI

$-0.01[-0.10,0.08]$

Comparison 04. High versus low intensity exercise with dietary change

\begin{tabular}{|c|c|c|c|c|}
\hline Outcome title & $\begin{array}{l}\text { No. of } \\
\text { studies }\end{array}$ & $\begin{array}{c}\text { No. of } \\
\text { participants }\end{array}$ & Statistical method & Effect size \\
\hline 01 Weight change in kilograms & 7 & 224 & Weighted Mean Difference (Fixed) 95\% CI & $-0.08[-1.20,1.04]$ \\
\hline $\begin{array}{l}02 \text { Change in body mass index } \\
\text { (BMI) }\end{array}$ & & & Weighted Mean Difference (Fixed) 95\% CI & Totals not selected \\
\hline $\begin{array}{l}03 \text { Change in systolic blood } \\
\text { pressure }(\mathrm{mmHg})\end{array}$ & & & Weighted Mean Difference (Fixed) 95\% CI & Totals not selected \\
\hline $\begin{array}{l}04 \text { Change in diastolic blood } \\
\text { pressure }(\mathrm{mmHg})\end{array}$ & & & Weighted Mean Difference (Fixed) 95\% CI & Totals not selected \\
\hline $\begin{array}{l}05 \text { Change in serum cholesterol } \\
(\mathrm{mmol} / \mathrm{l})\end{array}$ & & & Weighted Mean Difference (Fixed) 95\% CI & Totals not selected \\
\hline $\begin{array}{l}06 \text { Change in serum triglycerides } \\
(\mathrm{mmol} / \mathrm{l})\end{array}$ & 2 & 65 & Weighted Mean Difference (Fixed) 95\% CI & $0.00[-0.18,0.19]$ \\
\hline $\begin{array}{l}07 \text { Change in serum HDL } \\
(\mathrm{mmol} / \mathrm{l})\end{array}$ & 2 & 65 & Weighted Mean Difference (Fixed) 95\% CI & $0.03[-0.05,0.11]$ \\
\hline $\begin{array}{l}08 \text { Change in serum glucose } \\
(\mathrm{mmol} / \mathrm{l})\end{array}$ & & & Weighted Mean Difference (Fixed) 95\% CI & Totals not selected \\
\hline
\end{tabular}

\section{Comparison 05. High versus low intensity exercise without dietary change}

\begin{tabular}{|c|c|c|c|c|}
\hline Outcome title & $\begin{array}{l}\text { No. of } \\
\text { studies }\end{array}$ & $\begin{array}{c}\text { No. of } \\
\text { participants }\end{array}$ & Statistical method & Effect size \\
\hline 01 Weight change in kilograms & 4 & 317 & Weighted Mean Difference (Fixed) 95\% CI & $-1.47[-2.28,-0.66]$ \\
\hline $\begin{array}{l}02 \text { Change in systolic blood } \\
\text { pressure }(\mathrm{mmHg})\end{array}$ & & & Weighted Mean Difference (Fixed) 95\% CI & Totals not selected \\
\hline $\begin{array}{l}03 \text { Change in diastolic blood } \\
\text { pressure }\end{array}$ & & & Weighted Mean Difference (Fixed) 95\% CI & Totals not selected \\
\hline $\begin{array}{l}04 \text { Change in serum triglycerides } \\
(\mathrm{mmol} / \mathrm{l})\end{array}$ & & & Weighted Mean Difference (Fixed) 95\% CI & Totals not selected \\
\hline $\begin{array}{l}05 \text { Change in serum HDL } \\
(\mathrm{mmol} / \mathrm{l})\end{array}$ & & & Weighted Mean Difference (Fixed) 95\% CI & Totals not selected \\
\hline $\begin{array}{l}06 \text { Change in serum glucose } \\
(\mathrm{mmol} / \mathrm{l})\end{array}$ & 2 & 46 & Weighted Mean Difference (Fixed) 95\% CI & $-0.31[-0.45,-0.16]$ \\
\hline
\end{tabular}

\section{INDEX TERMS}

\section{Medical Subject Headings (MeSH)}

*Diet, Reducing; *Exercise; Obesity [ ${ }^{*}$ therapy]; Overweight; Randomized Controlled Trials; Weight Loss 
MeSH check words

Adult; Humans

COVER SHEET

Title

Authors

Contribution of author(s)

Issue protocol first published

Review first published

Date of most recent amendment

Date of most recent

SUBSTANTIVE amendment

What's New

Date new studies sought but none found

Date new studies found but not yet included/excluded

Date new studies found and included/excluded

Date authors' conclusions section amended

Contact address
Exercise for overweight or obesity

Shaw K, Gennat H, O’Rourke P, Del Mar C

KELLY SHAW: Protocol development, literature search, assessment of trials and data extraction. Was also the principal reviewer performing the analysis and interpretation of data, as well as the development of the final review.

HANNI GENNAT: Assessment of trials, data extraction, data entry, quality scoring of trials.

PETER O'ROURKE: Resolution of differences of opinion between reviewers, statistical analysis, assistance in interpretation of data and development of the final review.

CHRISTOPHER DEL MAR: Assessment of trials and data extraction, assistance in development of the final review.

$2006 / 4$

l

22 August 2006

23 August 2006

Information not supplied by author

Information not supplied by author

Information not supplied by author

Information not supplied by author

Information not supplied by author

Dr Kelly Shaw

Public Health Physician

Public and Environmental Health Unit

Department of Health and Human Services

Public Health Unit

152 Macquarie Street

Hobart

Tasmania

7000

AUSTRALIA

E-mail: kelly.shaw@dhhs.tas.gov.au

Tel: +1110362227678

10.1002/14651858.CD003817.pub3

CD003817

Cochrane Metabolic and Endocrine Disorders Group
Cochrane Library number 


\title{
GRAPHS ANDOTHER TABLES
}

Figure $0 \mathrm{I}$.

\begin{abstract}
Review: Exercise for overweight or obesity
Comparison: 03 Exercise + diet versus diet alone

Outcome: 01 Weight change in kilograms
\end{abstract}

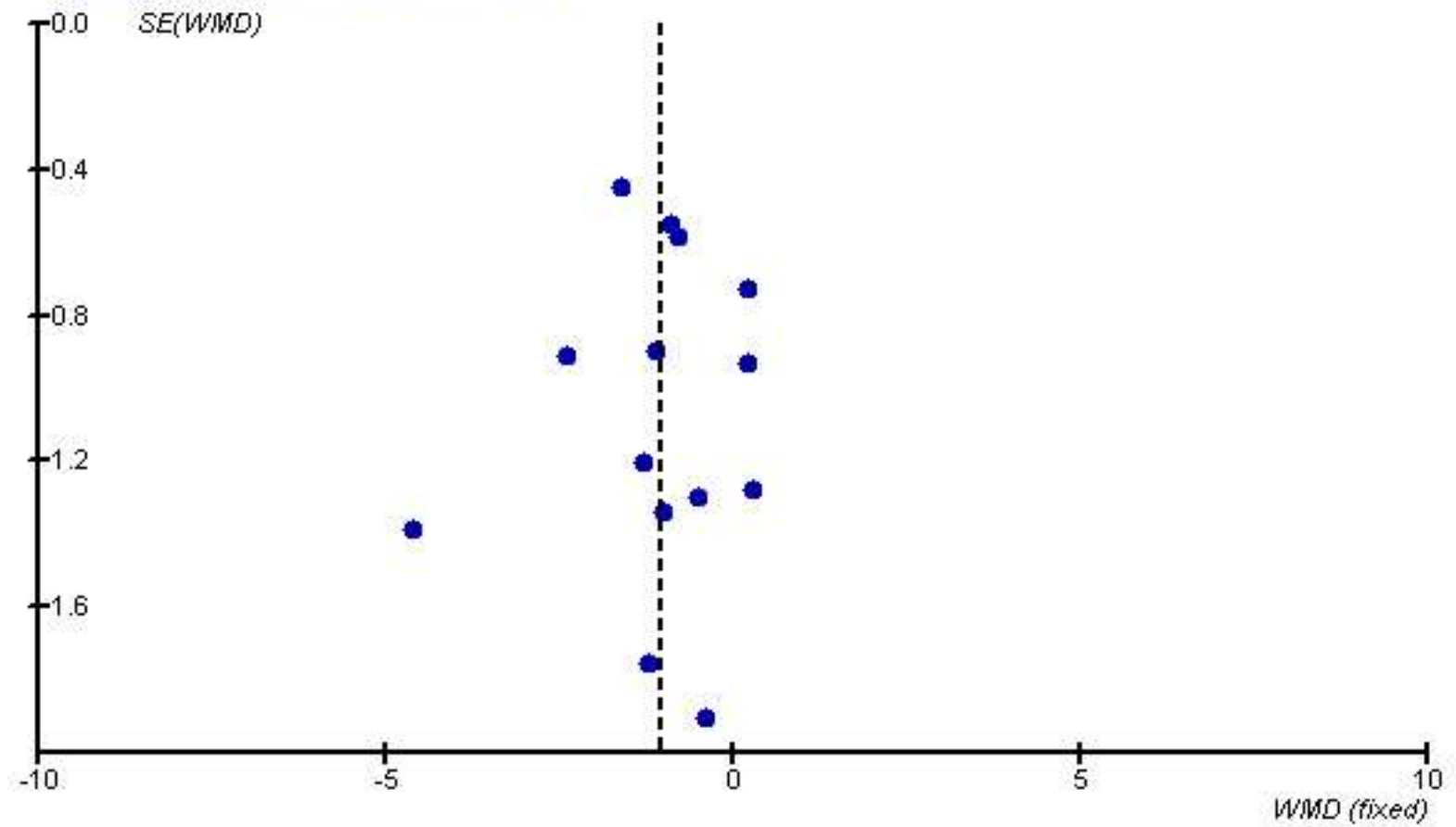


Analysis 0I.0I. Comparison $0 \mathrm{I}$ Exercise versus no treatment control, Outcome $0 \mathrm{I}$ Weight change in kilograms

Review: Exercise for overweight or obesity

Comparison: 01 Exercise versus no treatment control

Outcome: 01 Weight change in kilograms

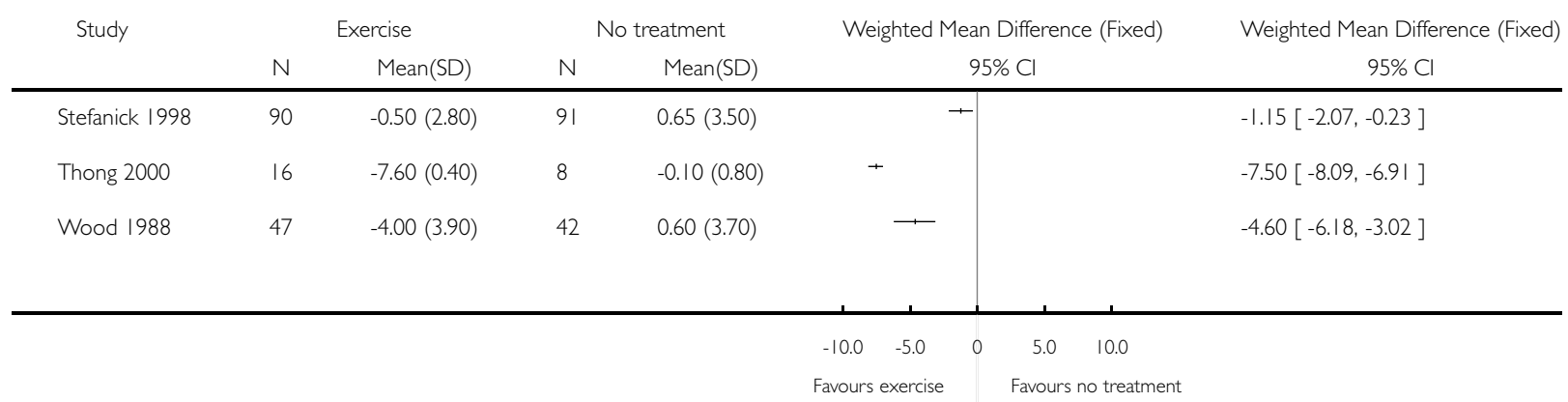

\section{Analysis 01.02. Comparison 01 Exercise versus no treatment control, Outcome 02 Change in body mass index (BMI)}

Review: Exercise for overweight or obesity

Comparison: 01 Exercise versus no treatment control

Outcome: 02 Change in body mass index (BMI)

\begin{tabular}{|c|c|c|c|c|c|c|c|}
\hline \multirow[t]{2}{*}{ Study } & \multicolumn{2}{|c|}{ Exercise } & \multicolumn{2}{|c|}{ No treatment } & \multirow{2}{*}{\multicolumn{2}{|c|}{$\begin{array}{l}\text { Weighted Mean Difference (Fixed) } \\
\qquad 95 \% \mathrm{Cl}\end{array}$}} & \multirow{2}{*}{$\begin{array}{l}\text { Weighted Mean Difference (Fixed) } \\
\qquad 95 \% \mathrm{Cl}\end{array}$} \\
\hline & $\mathrm{N}$ & Mean(SD) & $\mathrm{N}$ & Mean(SD) & & & \\
\hline Anderssen 1996 & 49 & $-0.65(1.50)$ & 43 & $0.36(0.80)$ & + & & $-1.01[-1.49,-0.53]$ \\
\hline Hellenius 1993 & 39 & $-0.30(0.80)$ & 39 & $0.30(0.64)$ & + & & $-0.60[-0.92,-0.28]$ \\
\hline Thong 2000 & 16 & $-2.40(0.40)$ & 8 & $-0.03(0.30)$ & + & & $-2.37[-2.66,-2.08]$ \\
\hline & & & & & $-10.0 \quad-5.0$ & 10.0 & \\
\hline
\end{tabular}

Analysis 01.03. Comparison 01 Exercise versus no treatment control, Outcome 03 Change in systolic blood pressure $(\mathbf{m m H g})$

Review: Exercise for overweight or obesity

Comparison: 01 Exercise versus no treatment control

Outcome: 03 Change in systolic blood pressure $(\mathrm{mmHg})$

\begin{tabular}{|c|c|c|c|c|c|c|c|}
\hline \multirow[t]{2}{*}{ Study } & \multicolumn{2}{|c|}{ Exercise } & \multicolumn{2}{|c|}{ No treatment } & \multirow{2}{*}{\multicolumn{2}{|c|}{$\begin{array}{l}\text { Weighted Mean Difference (Fixed) } \\
\qquad 95 \% \mathrm{Cl}\end{array}$}} & \multirow{2}{*}{$\begin{array}{l}\text { Weighted Mean Difference (Fixed) } \\
\qquad 95 \% \mathrm{Cl}\end{array}$} \\
\hline & N & Mean(SD) & $N$ & Mean(SD) & & & \\
\hline Hellenius 1993 & 39 & $-5.00(13.90)$ & 39 & $-1.00(6.40)$ & & T & $-4.00[-8.80,0.80]$ \\
\hline \multirow[t]{3}{*}{ Stefanick 1998} & 90 & $-0.80(8.10)$ & 91 & $-1.00(7.70)$ & - & 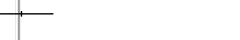 & $0.20[-2.10,2.50]$ \\
\hline & & & & & $\begin{array}{ll}-10.0 & -5.0\end{array}$ & 10.0 & \\
\hline & & & & & Favours exercise & Favours no treatment & \\
\hline
\end{tabular}

Exercise for overweight or obesity (Review) 
Analysis 01.04. Comparison 01 Exercise versus no treatment control, Outcome 04 Change in diastolic blood pressure $(\mathrm{mmHg})$

Review: Exercise for overweight or obesity

Comparison: 0 I Exercise versus no treatment control

Outcome: 04 Change in diastolic blood pressure $(\mathrm{mmHg})$

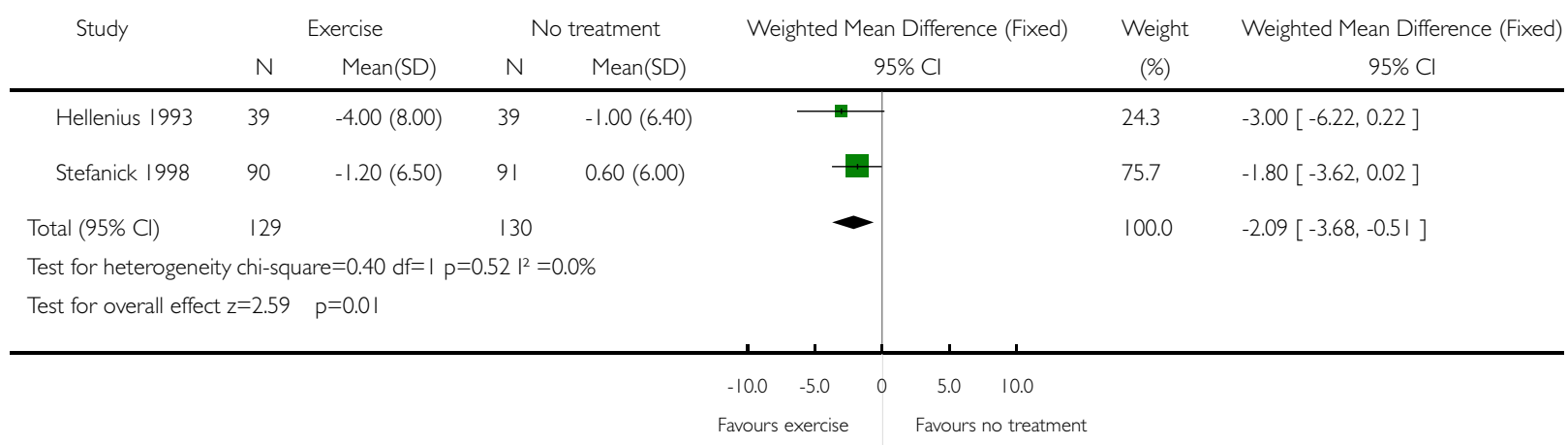

\section{Analysis 01.05. Comparison 01 Exercise versus no treatment control, Outcome 05 Change in total serum} cholesterol (mmol/l)

Review: Exercise for overweight or obesity

Comparison: 0 I Exercise versus no treatment control

Outcome: 05 Change in total serum cholesterol $(\mathrm{mmol} / \mathrm{l})$

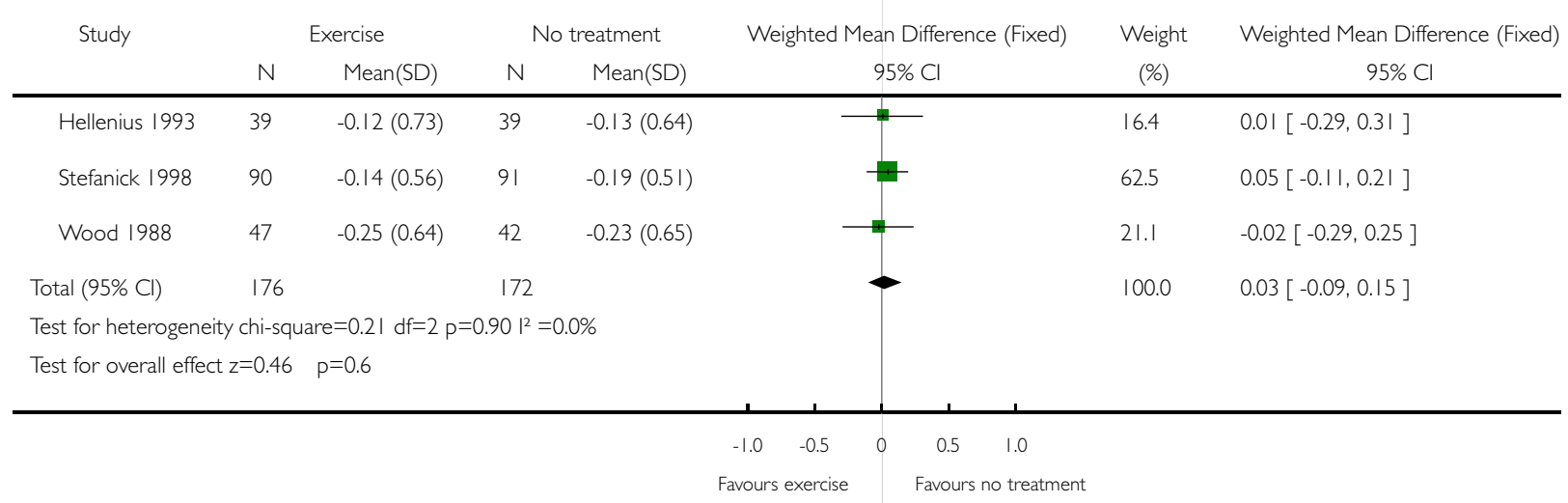




\section{Analysis 01.06. Comparison $0 \mathrm{I}$ Exercise versus no treatment control, Outcome 06 Change in serum}

triglycerides (mmol/l)

Review: Exercise for overweight or obesity

Comparison: 0 I Exercise versus no treatment control

Outcome: 06 Change in serum triglycerides $(\mathrm{mmol} / \mathrm{l})$

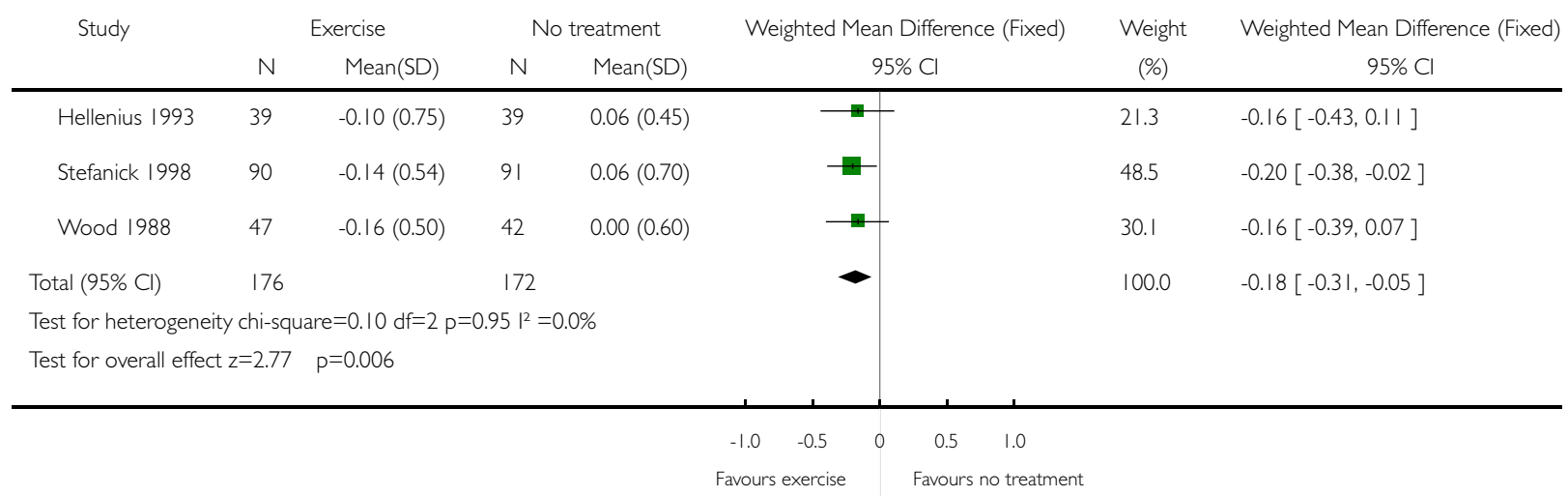

Analysis 01.07. Comparison 01 Exercise versus no treatment control, Outcome 07 Change in serum HDL $(\mathrm{mmol} / \mathrm{l})$

Review: Exercise for overweight or obesity

Comparison: 0 l Exercise versus no treatment control

Outcome: 07 Change in serum HDL ( $\mathrm{mmol} / \mathrm{l})$

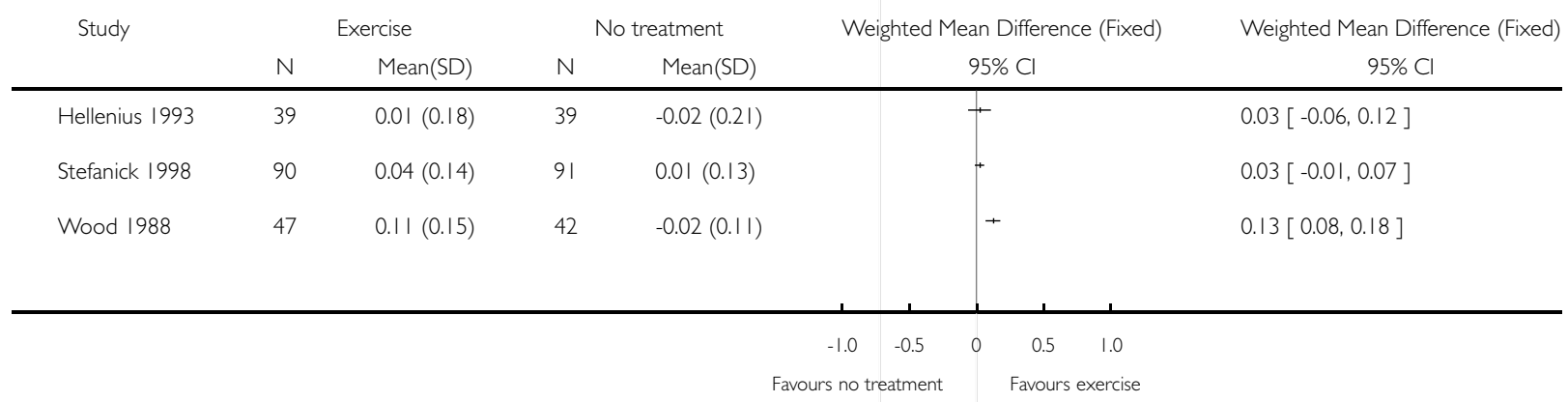


Analysis 01.08. Comparison $0 \mathrm{I}$ Exercise versus no treatment control, Outcome 08 Change in fasting serum glucose (mmol/l)

Review: Exercise for overweight or obesity

Comparison: 0 I Exercise versus no treatment control

Outcome: 08 Change in fasting serum glucose $(\mathrm{mmol} / \mathrm{l})$

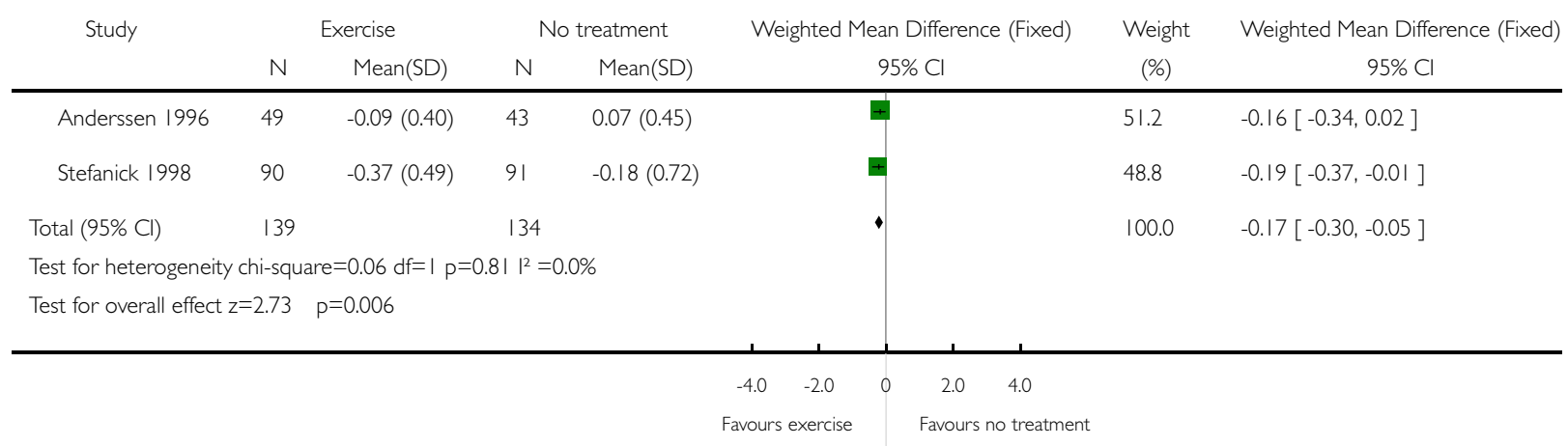

\section{Analysis 02.01. Comparison 02 Exercise versus diet, Outcome 01 Weight change in kilograms}

Review: Exercise for overweight or obesity

Comparison: 02 Exercise versus diet

Outcome: 01 Weight change in kilograms

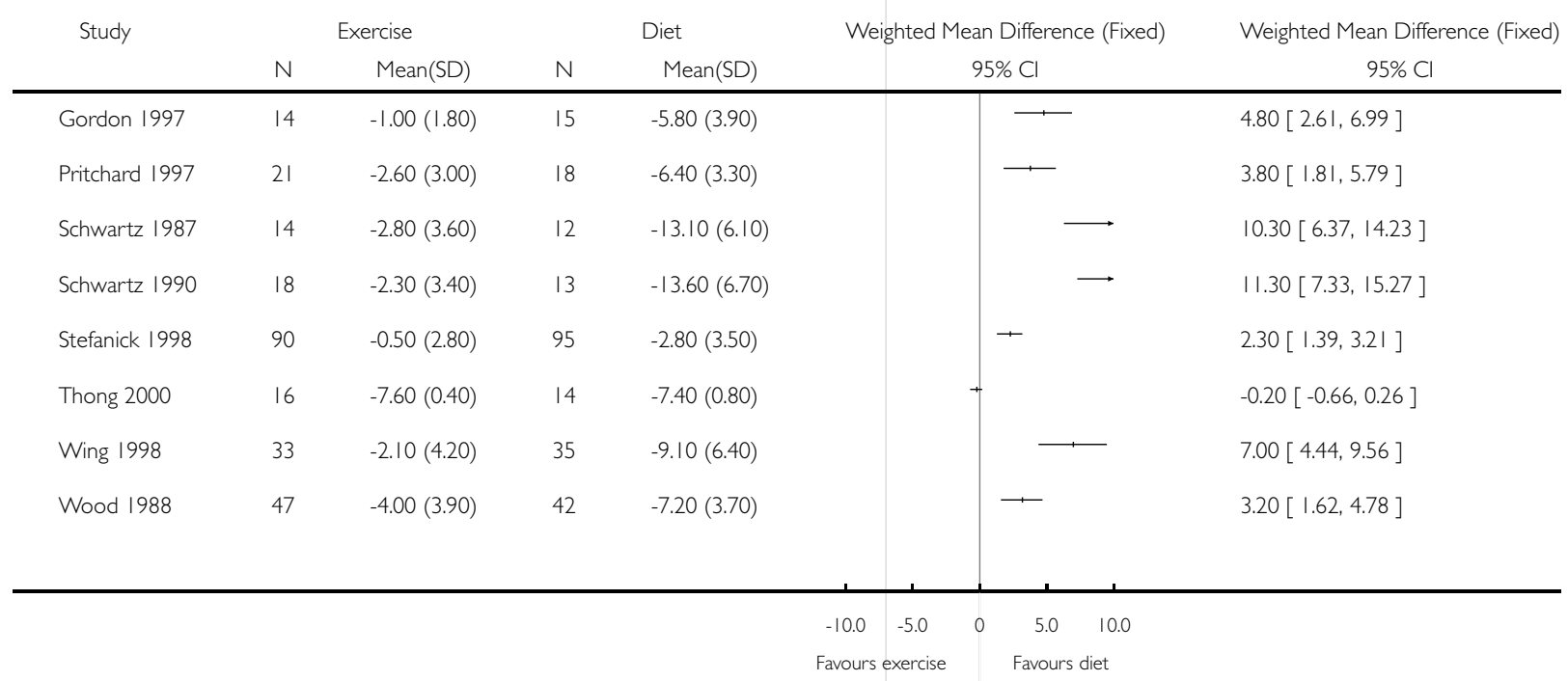


Analysis 02.02. Comparison 02 Exercise versus diet, Outcome 02 Change in body mass index (BMI)

Review: Exercise for overweight or obesity

Comparison: 02 Exercise versus diet

Outcome: 02 Change in body mass index (BMI)

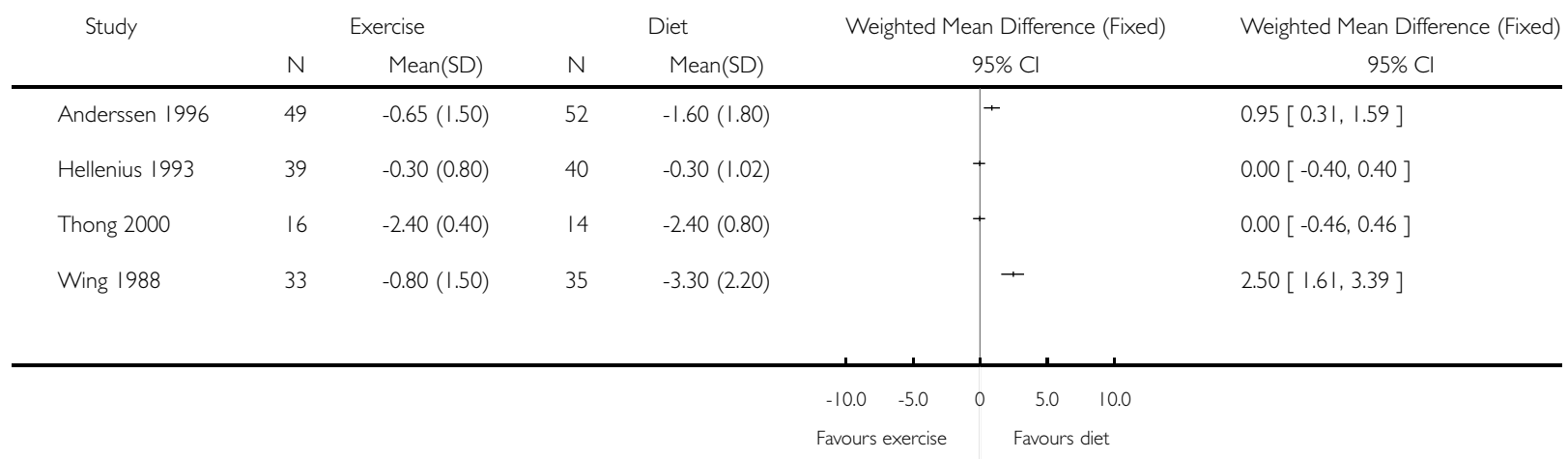

Analysis 02.03. Comparison 02 Exercise versus diet, Outcome 03 Change in systolic blood pressure ( $\mathrm{mmHg})$

Review: Exercise for overweight or obesity

Comparison: 02 Exercise versus diet

Outcome: 03 Change in systolic blood pressure $(\mathrm{mmHg})$

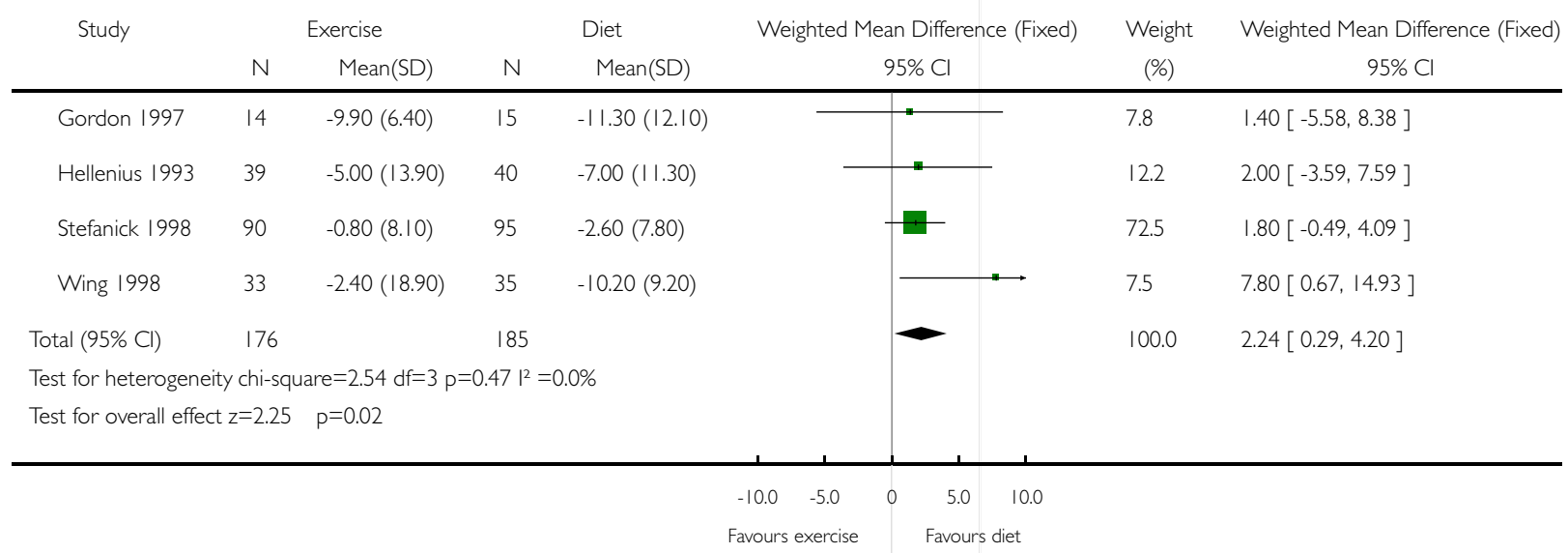




\section{Analysis 02.04. Comparison 02 Exercise versus diet, Outcome 04 Change in diastolic blood pressure ( $\mathrm{mmHg}$ )}

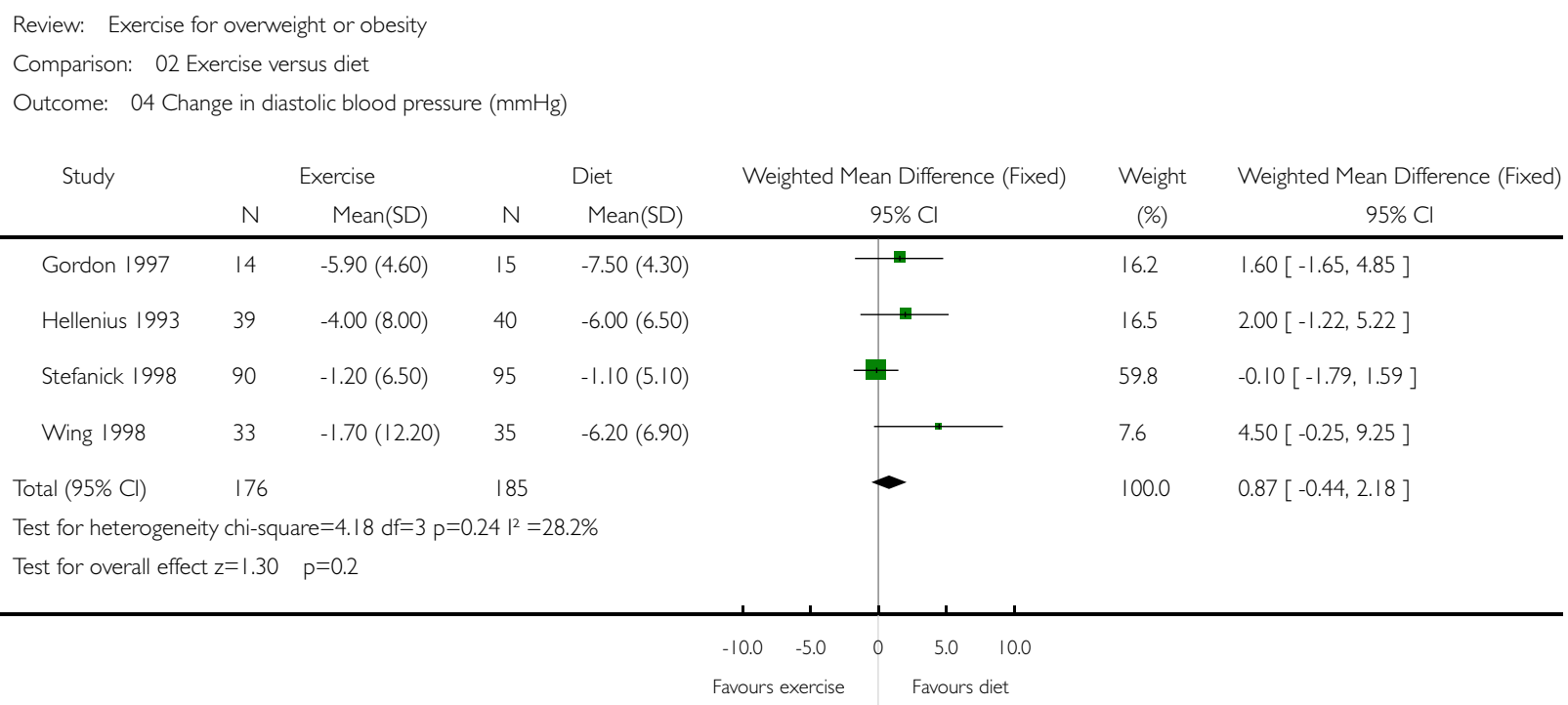

\section{Analysis 02.05. Comparison 02 Exercise versus diet, Outcome 05 Change in total serum cholesterol (mmol/l)}

Review: Exercise for overweight or obesity

Comparison: 02 Exercise versus diet

Outcome: 05 Change in total serum cholesterol (mmo//)

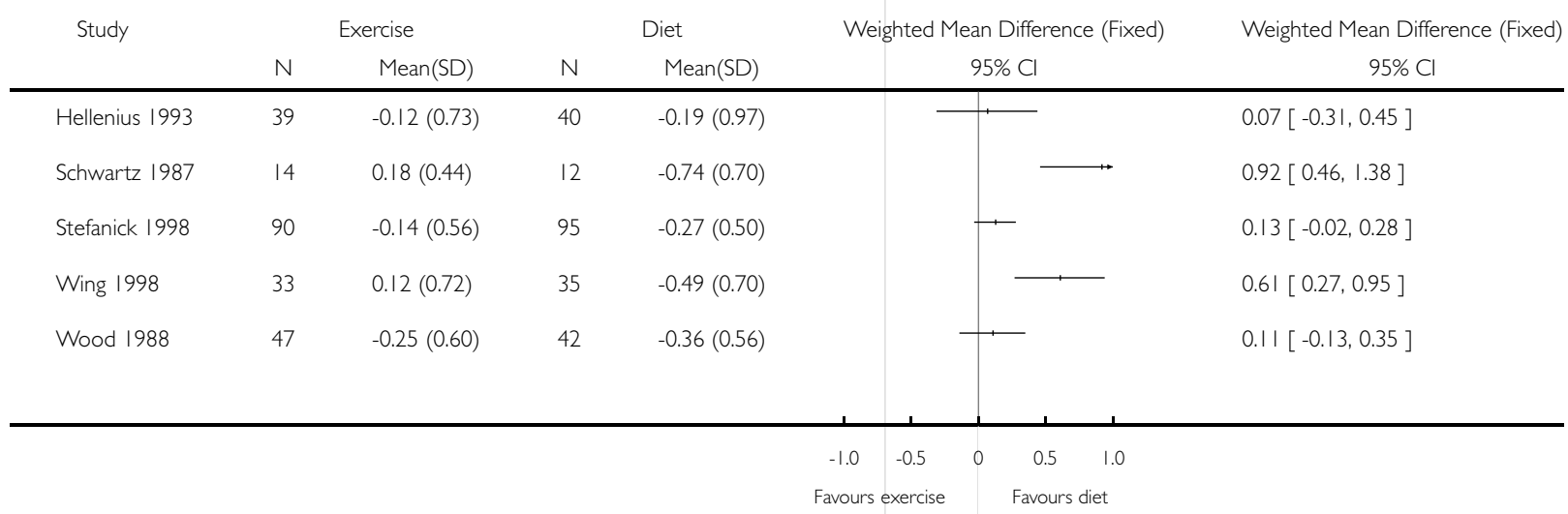


Analysis 02.06. Comparison 02 Exercise versus diet, Outcome 06 Change in serum triglycerides (mmol/l) Review: Exercise for overweight or obesity Comparison: 02 Exercise versus diet

Outcome: 06 Change in serum triglycerides ( $\mathrm{mmol} / \mathrm{l})$

\begin{tabular}{|c|c|c|c|c|c|c|}
\hline \multirow[t]{2}{*}{ Study } & \multicolumn{2}{|c|}{ Exercise } & \multicolumn{2}{|c|}{ Diet } & \multirow{2}{*}{$\begin{array}{l}\text { Weighted Mean Difference (Fixed) } \\
\qquad 95 \% \mathrm{Cl}\end{array}$} & \multirow{2}{*}{$\begin{array}{l}\text { Weighted Mean Difference (Fixed) } \\
\qquad 95 \% \mathrm{Cl} \\
\end{array}$} \\
\hline & $\mathrm{N}$ & Mean(SD) & $N$ & Mean(SD) & & \\
\hline Hellenius 1993 & 39 & $-0.10(0.75)$ & 40 & $0.03(0.39)$ & $\longrightarrow$ & $-0.13[-0.39,0.13]$ \\
\hline Schwartz 1987 & 14 & $-0.02(0.40)$ & 12 & $-0.60(0.75)$ & & $0.58[0.11,1.05]$ \\
\hline Stefanick 1998 & 90 & $-0.14(0.54)$ & 95 & $-0.06(0.70)$ & & $-0.08[-0.26,0.10]$ \\
\hline Wing 1998 & 33 & $0.12(1.64)$ & 35 & $-0.30(1.50)$ & $\longrightarrow$ & $0.42[-0.33,1.17]$ \\
\hline Wood 1988 & 47 & $-0.16(0.50)$ & 42 & $-0.27(0.72)$ & 1 & $0.11[-0.15,0.37]$ \\
\hline & & & & & -0.5 & \\
\hline
\end{tabular}

\section{Analysis 02.07. Comparison 02 Exercise versus diet, Outcome 07 Change in serum HDL (mmol/l)}

Review: Exercise for overweight or obesity

Comparison: 02 Exercise versus diet

Outcome: 07 Change in serum HDL ( $\mathrm{mmol} / \mathrm{l})$

\begin{tabular}{|c|c|c|c|c|c|c|}
\hline \multirow[t]{2}{*}{ Study } & \multicolumn{2}{|c|}{ Exercise } & \multicolumn{2}{|c|}{ Diet } & \multirow{2}{*}{$\begin{array}{l}\text { Weighted Mean Difference (Fixed) } \\
\qquad 95 \% \mathrm{Cl}\end{array}$} & \multirow{2}{*}{$\begin{array}{l}\text { Weighted Mean Difference (Fixed) } \\
\qquad 95 \% \mathrm{Cl}\end{array}$} \\
\hline & $\mathrm{N}$ & Mean(SD) & $N$ & Mean(SD) & & \\
\hline Hellenius 1993 & 39 & $0.01(0.18)$ & 40 & $0.01(0.19)$ & - & $0.00[-0.08,0.08]$ \\
\hline Schwartz 1987 & 14 & $0.08(0.08)$ & 12 & $0.10(0.23)$ & $\rightarrow$ & $-0.02[-0.16,0.12]$ \\
\hline Stefanick 1998 & 90 & $0.04(0.14)$ & 95 & $-0.01(0.13)$ & + & $0.05[0.01,0.09]$ \\
\hline Wing 1998 & 33 & $0.02(0.16)$ & 35 & $0.10(0.20)$ & + & $-0.08[-0.17,0.01]$ \\
\hline Wood 1988 & 47 & $0.11(0.15)$ & 42 & $0.12(0.16)$ & - & $-0.01[-0.07,0.05]$ \\
\hline & & & & & 0.5 & \\
\hline
\end{tabular}




\section{Analysis 02.08. Comparison 02 Exercise versus diet, Outcome 08 Change in fasting serum glucose (mmol/l)}

Review: Exercise for overweight or obesity

Comparison: 02 Exercise versus diet

Outcome: 08 Change in fasting serum glucose $(\mathrm{mmol} / \mathrm{l})$

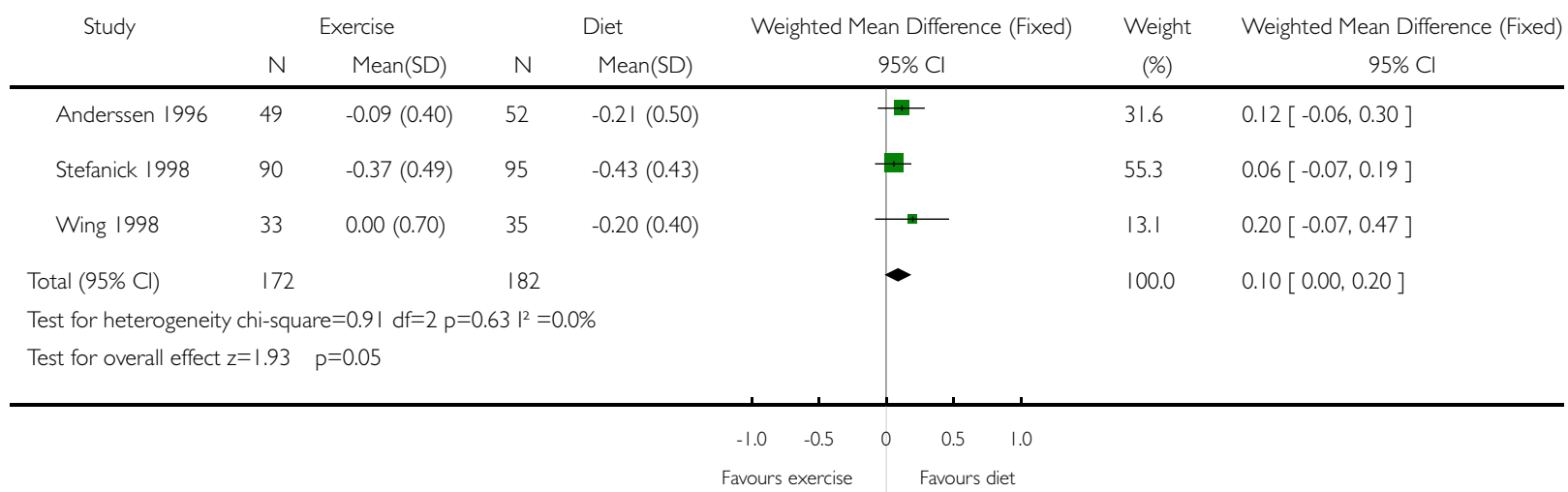

\section{Analysis 03.01. Comparison 03 Exercise + diet versus diet alone, Outcome 0 I Weight change in kilograms}

Review: Exercise for overweight or obesity

Comparison: 03 Exercise + diet versus diet alone

Outcome: 0 I Weight change in kilograms

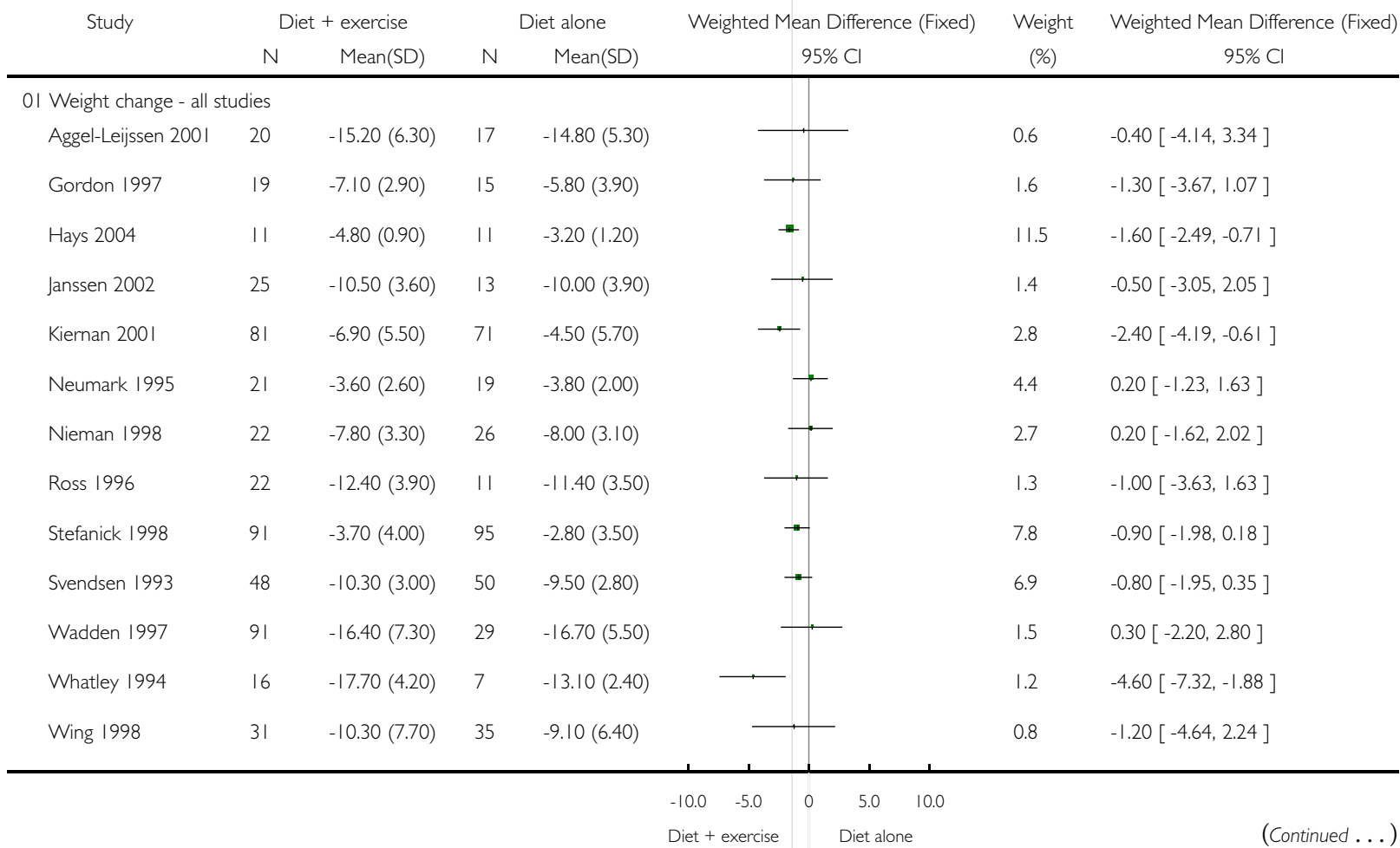


(... Continued $)$

\begin{tabular}{|c|c|c|c|c|c|c|c|}
\hline \multirow[t]{2}{*}{ Study } & \multicolumn{2}{|c|}{ Diet + exercise } & \multicolumn{2}{|c|}{ Diet alone } & \multirow{2}{*}{$\begin{array}{l}\text { Weighted Mean Difference (Fixed) } \\
\qquad 95 \% \mathrm{Cl}\end{array}$} & \multirow{2}{*}{$\begin{array}{c}\text { Weight } \\
(\%)\end{array}$} & \multirow{2}{*}{$\begin{array}{l}\text { Weighted Mean Difference (Fixed) } \\
\qquad 95 \% \mathrm{Cl}\end{array}$} \\
\hline & $\mathrm{N}$ & Mean(SD) & $\mathrm{N}$ & Mean(SD) & & & \\
\hline Wood I99| & 81 & $-3.40(4.90)$ & 71 & $-2.30(6.00)$ & $\longrightarrow$ & 2.9 & $-1.10[-2.86,0.66]$ \\
\hline Subtotal $(95 \% \mathrm{Cl})$ & 579 & & 470 & & $\bullet$ & 47.5 & $-1.05[-1.49,-0.62]$ \\
\hline \multicolumn{8}{|c|}{ Test for heterogeneity chi-square $=16.68 \mathrm{df}=13 p=0.21 \mathrm{p}^{2}=22.1 \%$} \\
\hline \multicolumn{8}{|c|}{ Test for overall effect $z=4.73 \quad p<0.0000$ I } \\
\hline \multicolumn{8}{|c|}{02 Weight change - males } \\
\hline Aggel-Leijssen 200I & 20 & $-15.20(6.30)$ & 17 & $-14.80(5.30)$ & & 0.6 & $-0.40[-4.14,3.34]$ \\
\hline Ross 1996 & 22 & $-12.40(3.90)$ & 11 & $-11.40(3.50)$ & $\longrightarrow$ & 1.3 & $-1.00[-3.63,1.63]$ \\
\hline Subtotal $(95 \% \mathrm{Cl})$ & 42 & & 28 & & & 2.0 & $-0.80[-2.95,1.35]$ \\
\hline \multicolumn{8}{|c|}{ Test for heterogeneity chi-square $=0.07 \mathrm{df}=1 \mathrm{p}=0.80 \mathrm{I}^{2}=0.0 \%$} \\
\hline \multicolumn{8}{|c|}{ Test for overall effect $z=0.73 \quad p=0.5$} \\
\hline \multicolumn{8}{|c|}{03 Weight change - females } \\
\hline Janssen 2002 & 25 & $-10.50(3.60)$ & 13 & $-10.00(3.90)$ & $\longrightarrow$ & 1.4 & $-0.50[-3.05,2.05]$ \\
\hline Neumark 1995 & 21 & $-3.60(2.60)$ & 19 & $-3.80(2.00)$ & - & 4.4 & $0.20[-1.23,1.63]$ \\
\hline Nieman 1998 & 22 & $-7.80(3.30)$ & 26 & $-8.00(3.10)$ & $\longrightarrow$ & 2.7 & $0.20[-1.62,2.02]$ \\
\hline Svendsen 1993 & 48 & $-10.30(3.00)$ & 50 & $-9.50(2.80)$ & $\rightarrow$ & 6.9 & $-0.80[-1.95,0.35]$ \\
\hline Wadden 1997 & 91 & $-16.40(7.30)$ & 29 & $-16.70(5.50)$ & 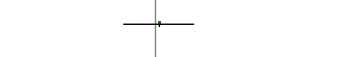 & 1.5 & $0.30[-2.20,2.80]$ \\
\hline Whatley 1994 & 16 & $-17.70(4.20)$ & 7 & $-13.10(2.40)$ & $\longrightarrow$ & 1.2 & $-4.60[-7.32,-1.88]$ \\
\hline Subtotal $(95 \% \mathrm{Cl})$ & 223 & & 144 & & $\bullet$ & 18.1 & $-0.55[-1.26,0.16]$ \\
\hline \multicolumn{8}{|c|}{ Test for heterogeneity chi-square $=10.85 \mathrm{df}=5 \mathrm{p}=0.05 \mathrm{I}^{2}=53.9 \%$} \\
\hline \multicolumn{8}{|c|}{ Test for overall effect $z=1.52 \quad p=0.1$} \\
\hline \multicolumn{8}{|c|}{04 Weight change - mean age $<45$ years } \\
\hline Aggel-Leijssen 200 I & 20 & $-15.20(6.30)$ & 17 & $-14.80(5.30)$ & & 0.6 & $-0.40[-4.14,3.34]$ \\
\hline Janssen 2002 & 25 & $-10.50(3.60)$ & 13 & $-10.00(3.90)$ & - & 1.4 & $-0.50[-3.05,2.05]$ \\
\hline Kiernan 200I & 81 & $-6.90(5.50)$ & 71 & $-4.50(5.70)$ & - & 2.8 & $-2.40[-4.19,-0.61]$ \\
\hline Ross 1996 & 22 & $-12.40(3.90)$ & 11 & $-11.40(3.50)$ & $\longrightarrow$ & 1.3 & $-1.00[-3.63,1.63]$ \\
\hline Wadden 1997 & 91 & $-16.40(7.30)$ & 29 & $-16.70(5.50)$ & 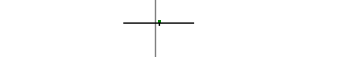 & 1.5 & $0.30[-2.20,2.80]$ \\
\hline Whatley 1994 & 16 & $-17.70(4.20)$ & 7 & $-13.10(2.40)$ & - & 1.2 & $-4.60[-7.32,-1.88]$ \\
\hline Subtotal $(95 \% \mathrm{Cl})$ & 255 & & 148 & & 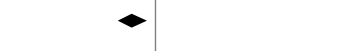 & 8.9 & $-1.61[-2.62,-0.60]$ \\
\hline \multicolumn{8}{|c|}{ Test for heterogeneity chi-square $=8.97 \mathrm{df}=5 \mathrm{p}=0.1 \mathrm{I} \mathrm{I}^{2}=44.3 \%$} \\
\hline \multicolumn{8}{|c|}{ Test for overall effect $z=3.12 \quad p=0.002$} \\
\hline \multicolumn{8}{|c|}{05 Weight change - mean age $>45$ years } \\
\hline Gordon 1997 & 19 & $-7.10(2.90)$ & 15 & $-5.80(3.90)$ & 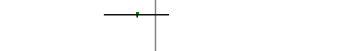 & 1.6 & $-1.30[-3.67,1.07]$ \\
\hline Hays 2004 & 11 & $-4.80(0.90)$ & 11 & $-3.20(1.20)$ & - & 11.5 & $-1.60[-2.49,-0.71]$ \\
\hline Nieman 1998 & 22 & $-7.80(3.30)$ & 26 & $-8.00(3.10)$ & 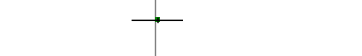 & 2.7 & $0.20[-1.62,2.02]$ \\
\hline Svendsen 1993 & 48 & $-10.30(3.00)$ & 50 & $-9.50(2.80)$ & $\rightarrow$ & 6.9 & $-0.80[-1.95,0.35]$ \\
\hline & & & & & 10.0 & & \\
\hline
\end{tabular}

Exercise for overweight or obesity (Review)

Copyright $\odot 2007$ The Cochrane Collaboration. Published by John Wiley \& Sons, Ltd 


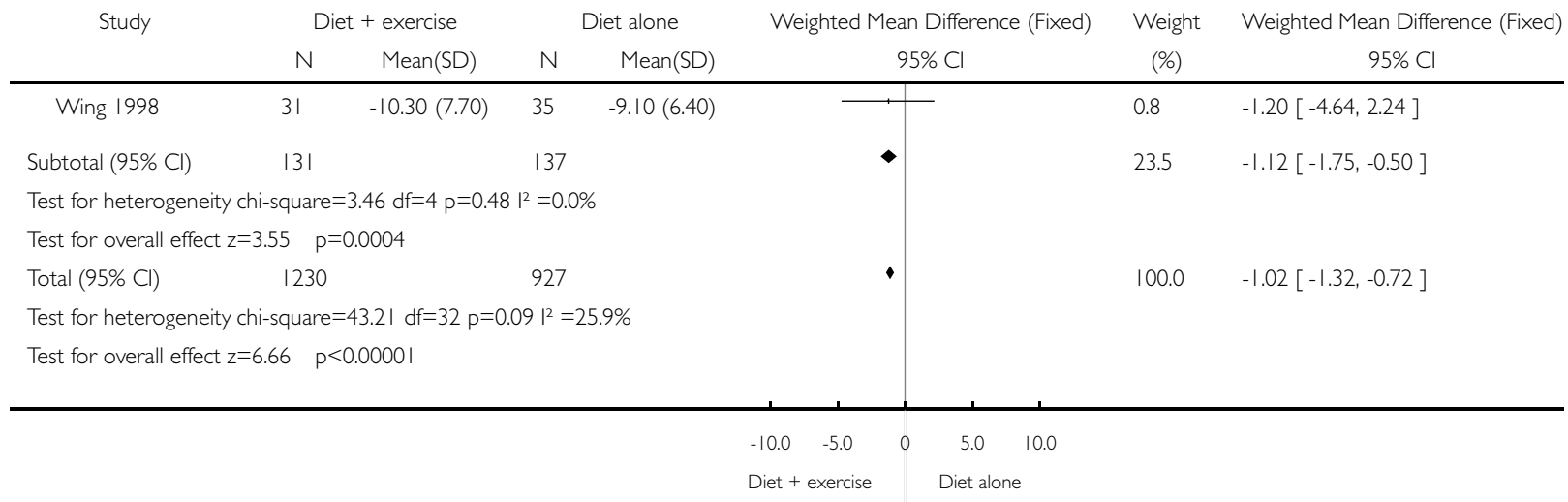

\section{Analysis 03.02. Comparison 03 Exercise + diet versus diet alone, Outcome 02 Change in body mass index}

(BMI)

Review: Exercise for overweight or obesity

Comparison: 03 Exercise + diet versus diet alone

Outcome: 02 Change in body mass index (BMI)

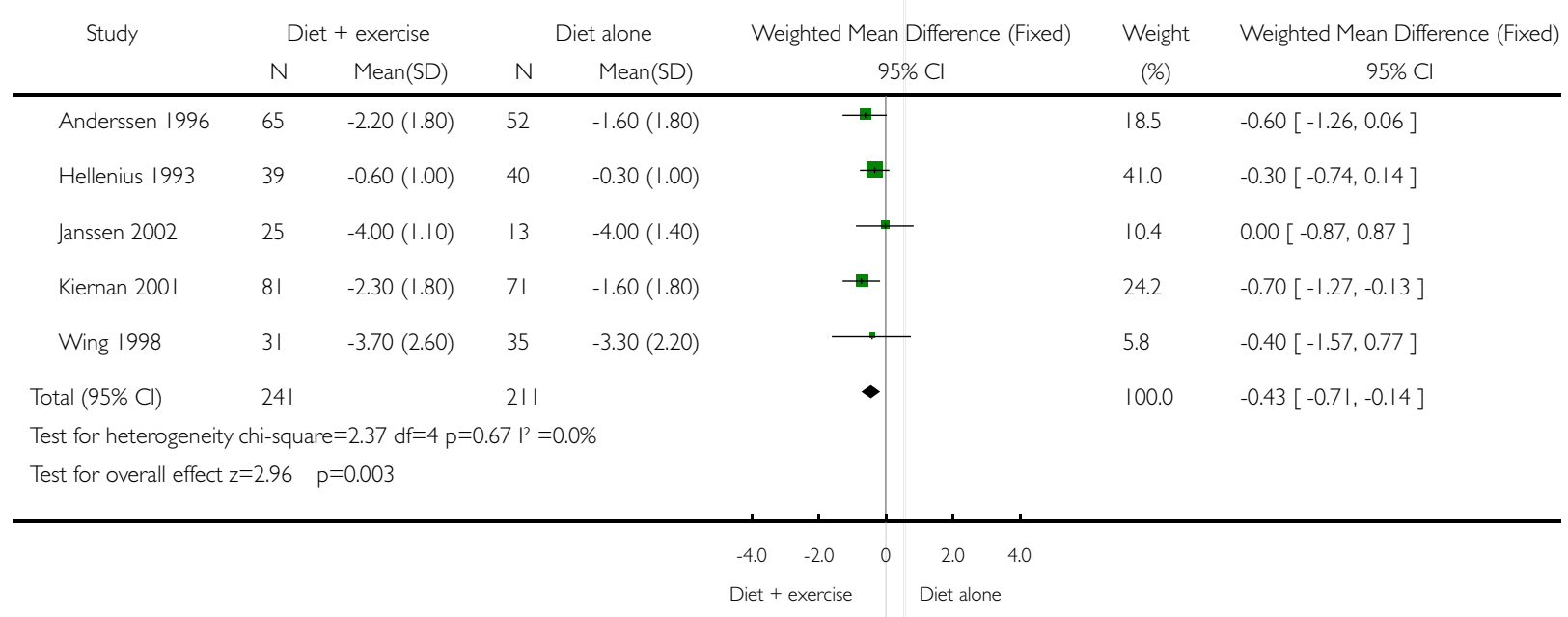




\section{Analysis 03.03. Comparison 03 Exercise + diet versus diet alone, Outcome 03 Change in systolic blood}

pressure $(\mathrm{mmHg})$

Review: Exercise for overweight or obesity

Comparison: 03 Exercise + diet versus diet alone

Outcome: 03 Change in systolic blood pressure $(\mathrm{mmHg})$

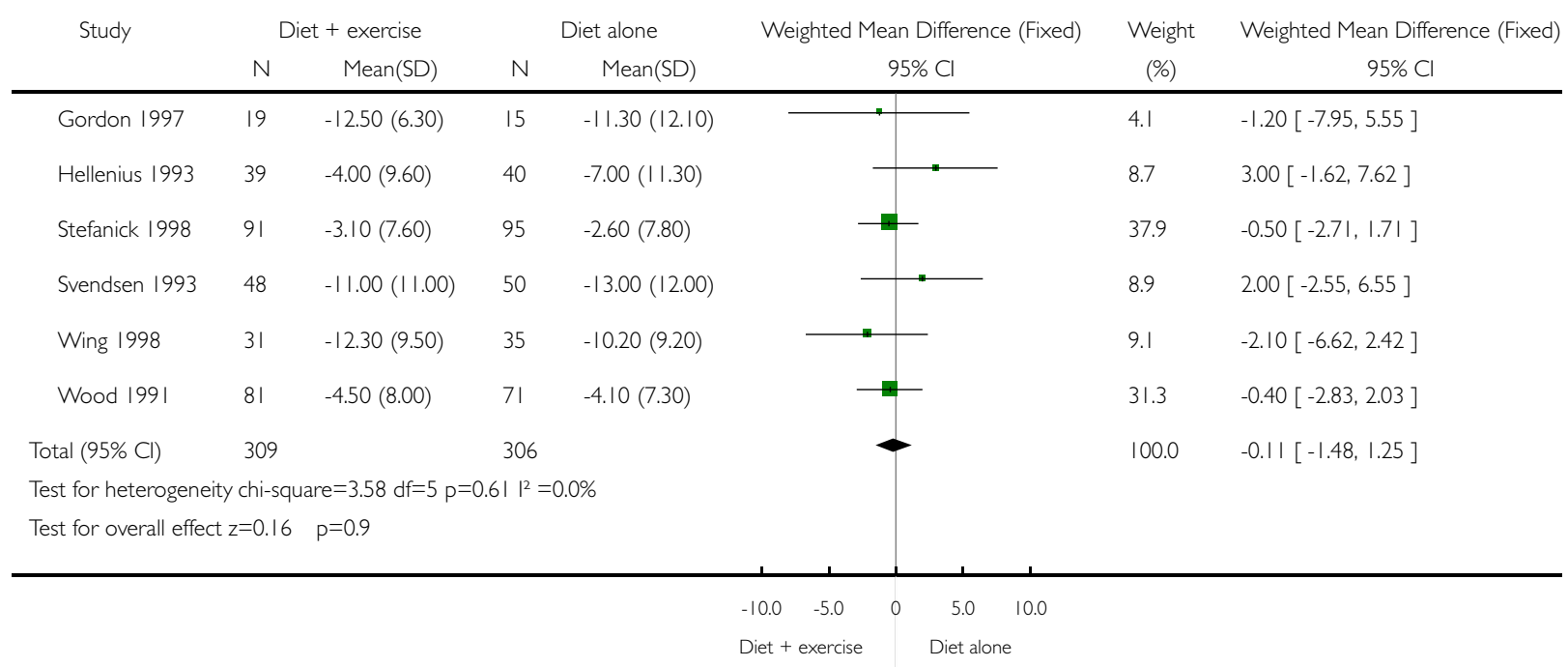

\section{Analysis 03.04. Comparison 03 Exercise + diet versus diet alone, Outcome 04 Change in diastolic blood} pressure $(\mathrm{mmHg})$

Review: Exercise for overweight or obesity

Comparison: 03 Exercise + diet versus diet alone

Outcome: 04 Change in diastolic blood pressure $(\mathrm{mmHg})$

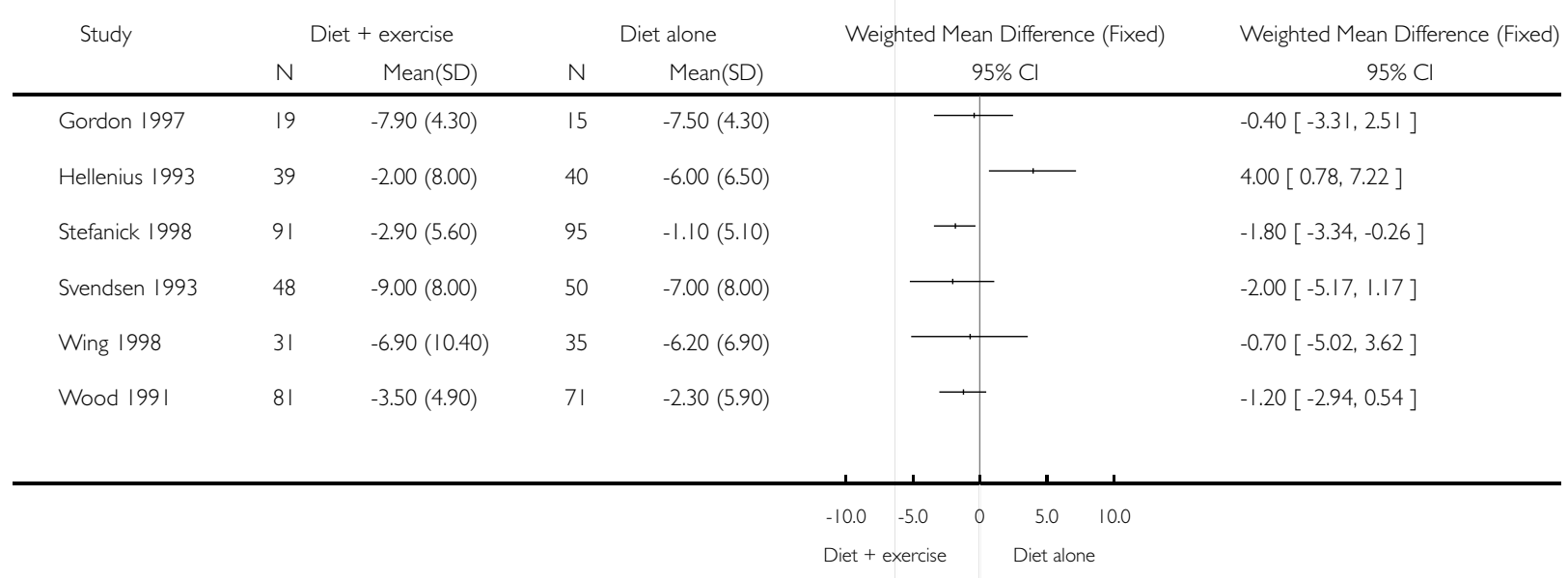




\section{Analysis 03.05. Comparison 03 Exercise + diet versus diet alone, Outcome 05 Change in total serum}

cholesterol (mmol/l)

Review: Exercise for overweight or obesity

Comparison: 03 Exercise + diet versus diet alone

Outcome: 05 Change in total serum cholesterol $(\mathrm{mmol} / \mathrm{l})$

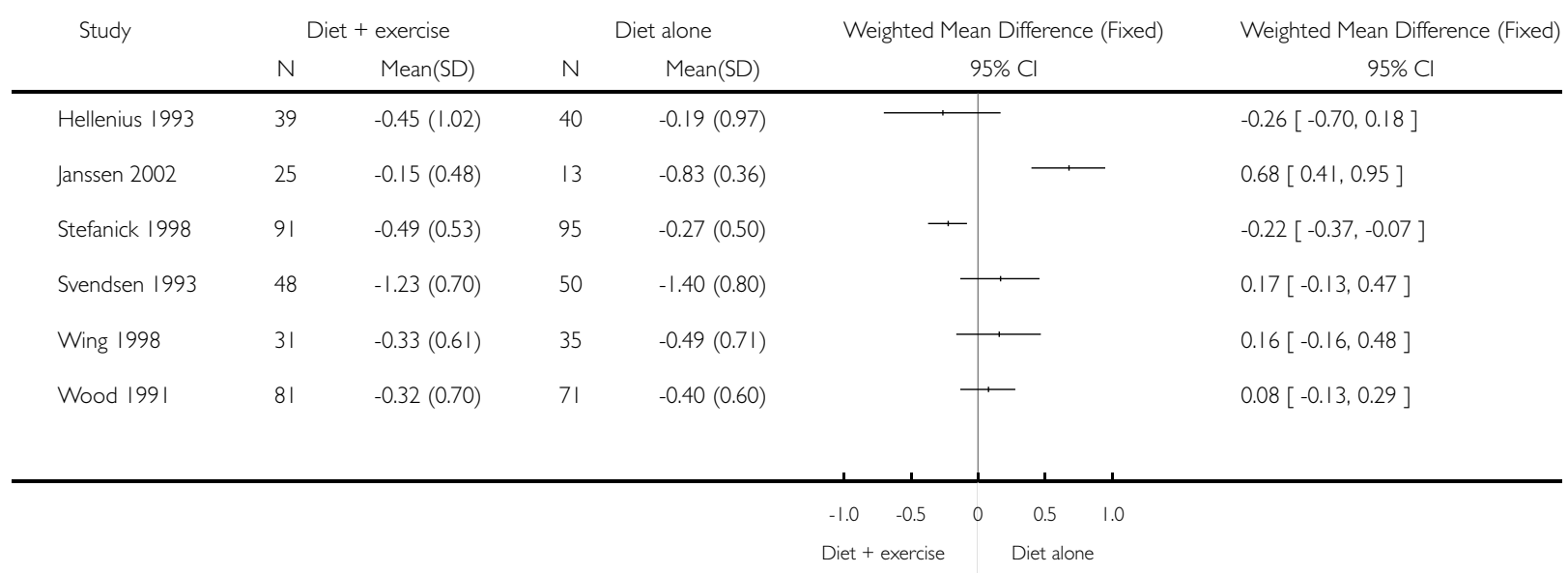

Analysis 03.06. Comparison 03 Exercise + diet versus diet alone, Outcome 06 Change in serum triglycerides $(\mathbf{m m o l} / \mathrm{l})$

Review: Exercise for overweight or obesity

Comparison: 03 Exercise + diet versus diet alone

Outcome: 06 Change in serum triglycerides ( $\mathrm{mmol} / \mathrm{l})$

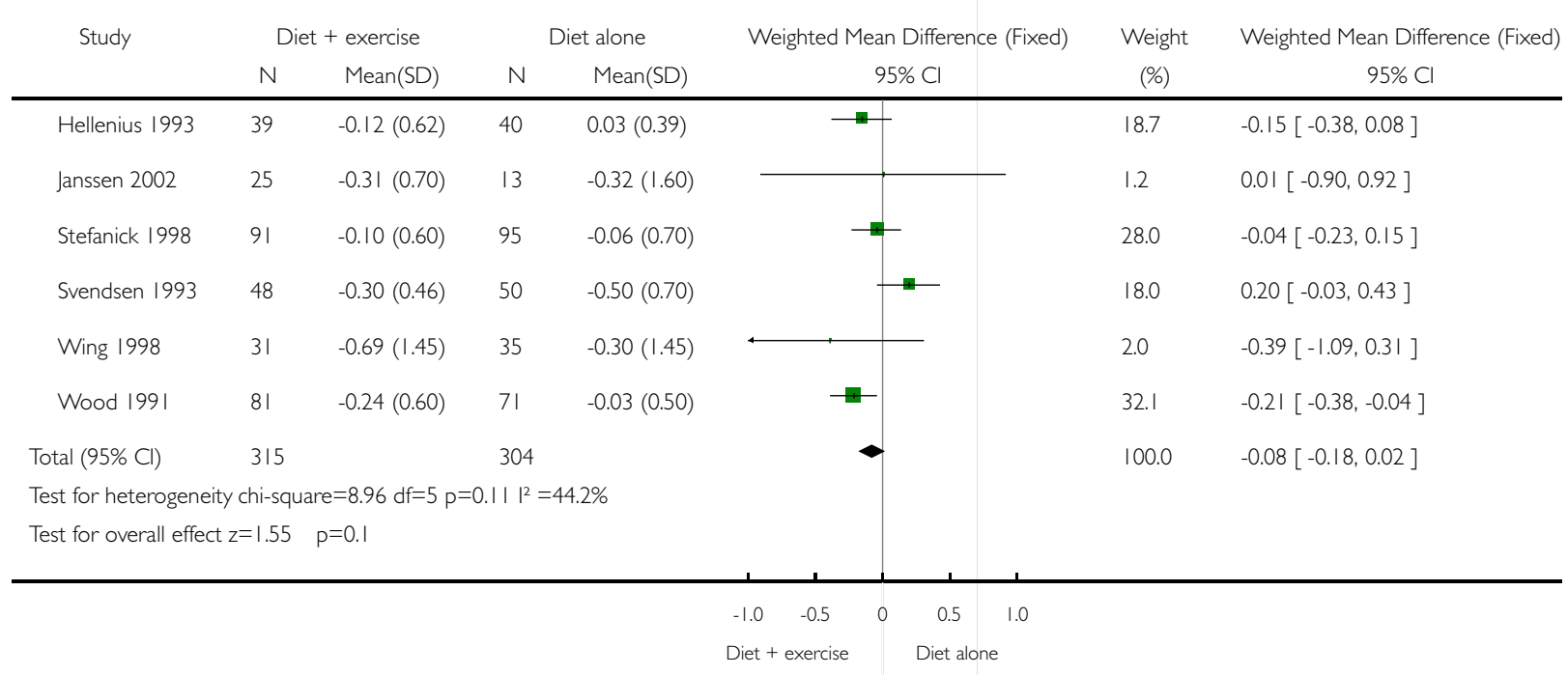

Exercise for overweight or obesity (Review) 


\section{Analysis 03.07. Comparison 03 Exercise + diet versus diet alone, Outcome 07 Change in serum HDL (mmol/l)}

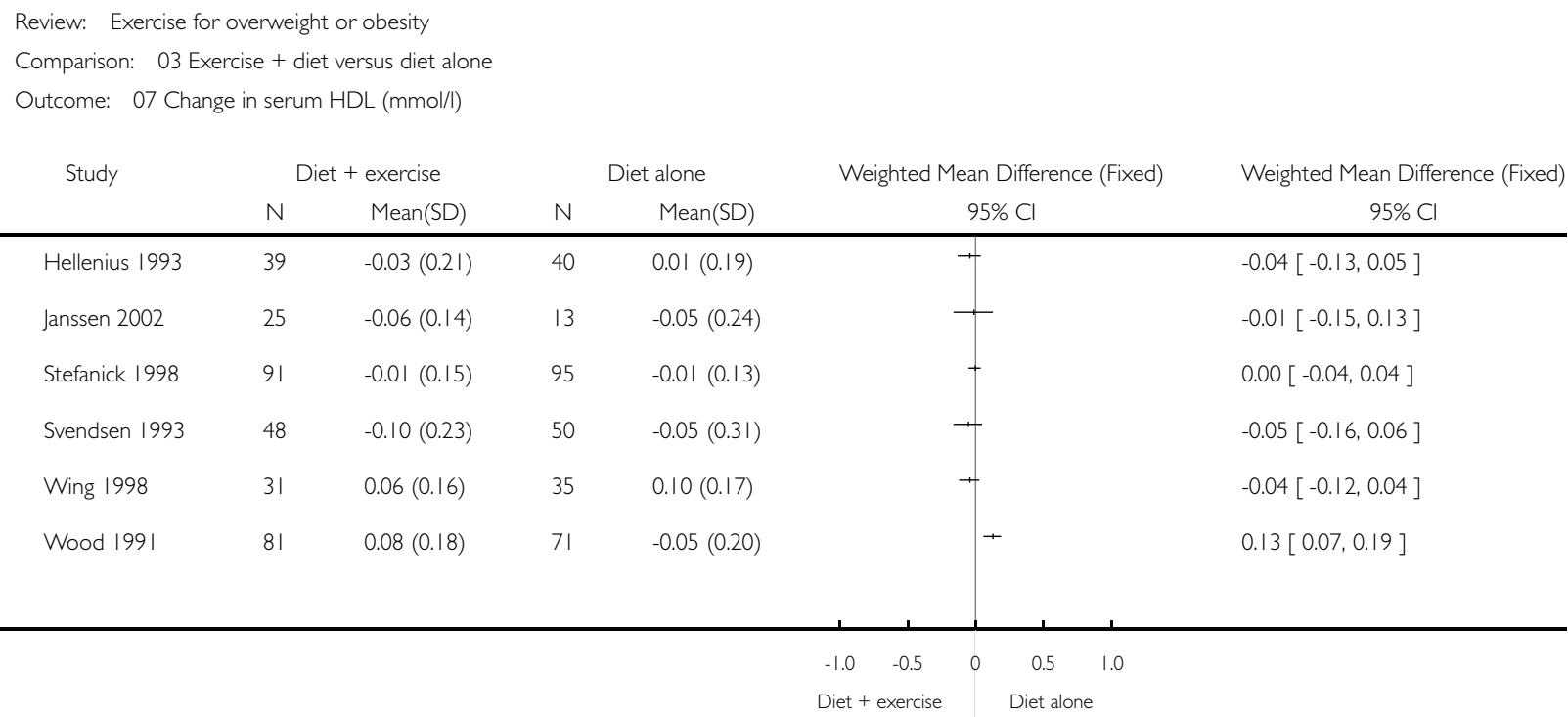

\section{Analysis 03.08. Comparison 03 Exercise + diet versus diet alone, Outcome 08 Change in fasting serum}

glucose $(\mathrm{mmol} / \mathrm{l})$

Review: Exercise for overweight or obesity

Comparison: 03 Exercise + diet versus diet alone

Outcome: 08 Change in fasting serum glucose $(\mathrm{mmol} / \mathrm{l})$

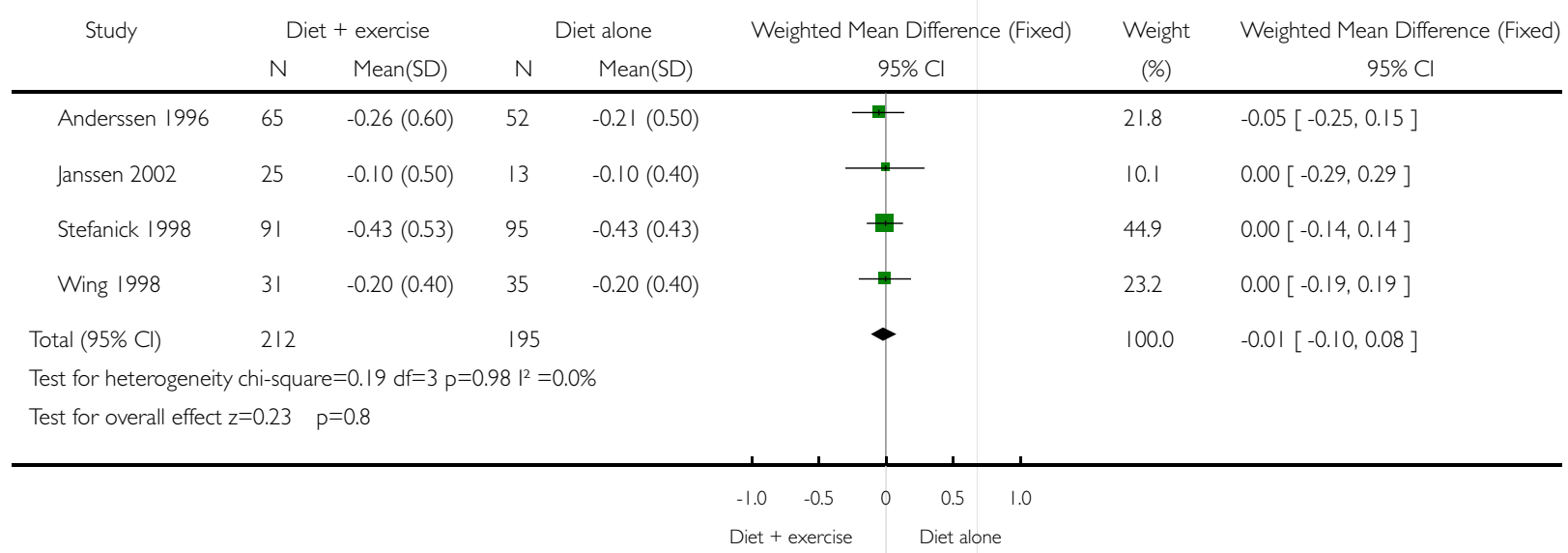


Analysis 04.01. Comparison 04 High versus low intensity exercise with dietary change, Outcome 01 Weight change in kilograms

Review: Exercise for overweight or obesity

Comparison: $04 \mathrm{High}$ versus low intensity exercise with dietary change

Outcome: 01 Weight change in kilograms

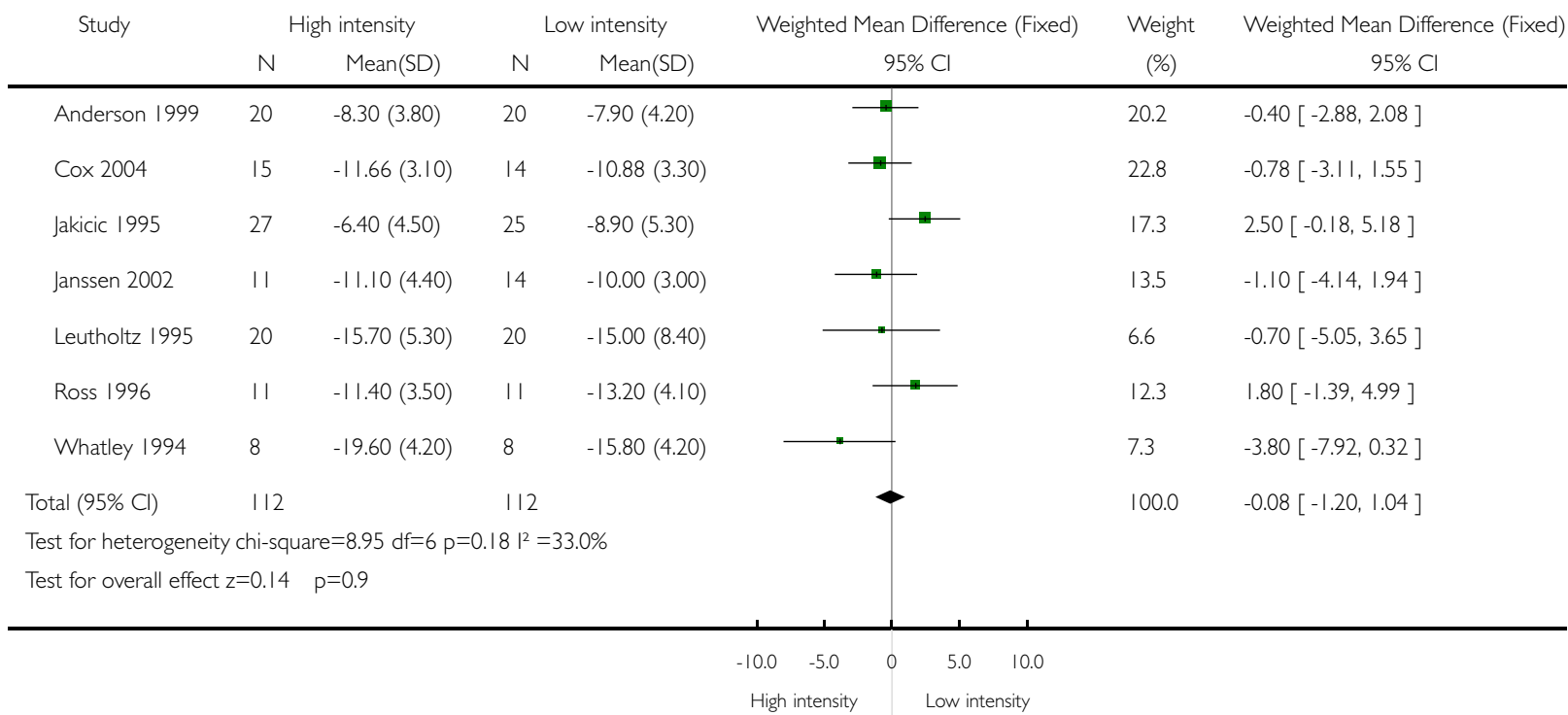

Analysis 04.02. Comparison 04 High versus low intensity exercise with dietary change, Outcome 02 Change in body mass index (BMI)

Review: Exercise for overweight or obesity

Comparison: $04 \mathrm{High}$ versus low intensity exercise with dietary change

Outcome: 02 Change in body mass index (BMI)

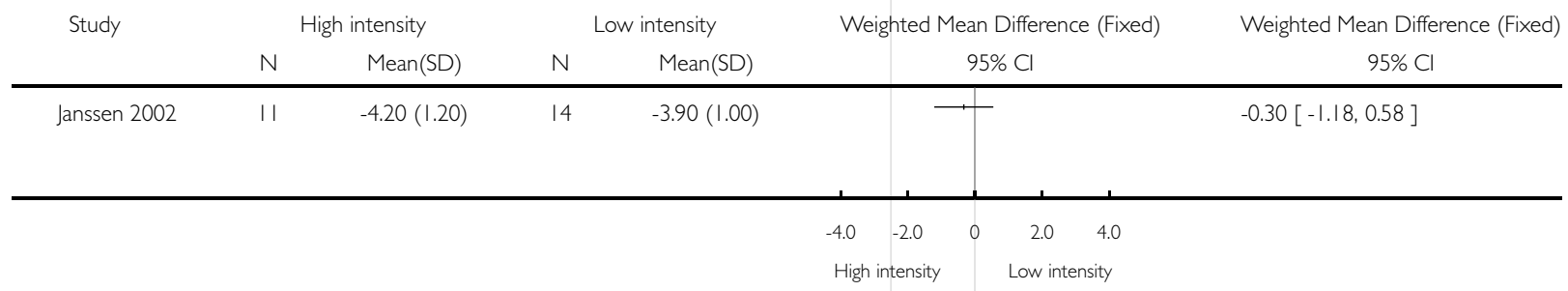


Analysis 04.03. Comparison 04 High versus low intensity exercise with dietary change, Outcome 03 Change in systolic blood pressure $(\mathrm{mmHg})$

Review: Exercise for overweight or obesity

Comparison: 04 High versus low intensity exercise with dietary change

Outcome: 03 Change in systolic blood pressure $(\mathrm{mmHg})$

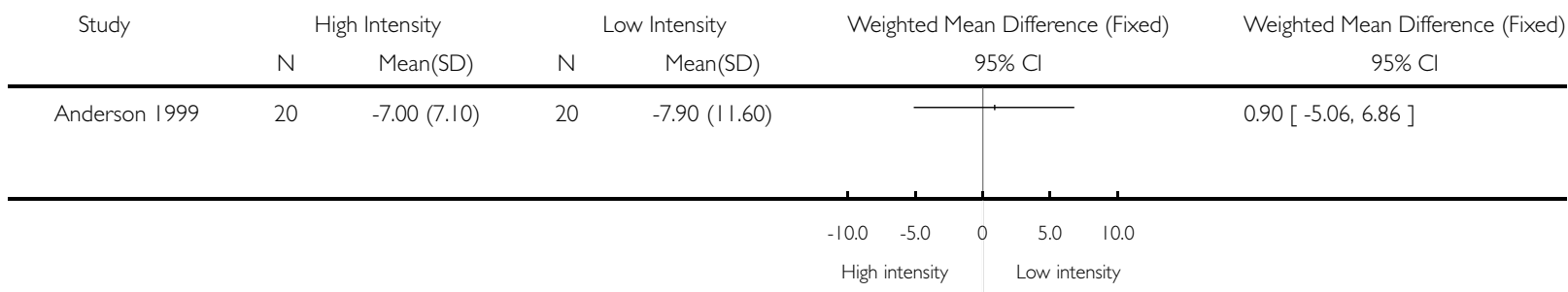

Analysis 04.04. Comparison 04 High versus low intensity exercise with dietary change, Outcome 04 Change in diastolic blood pressure $(\mathbf{m m H g})$

Review: Exercise for overweight or obesity

Comparison: 04 High versus low intensity exercise with dietary change

Outcome: 04 Change in diastolic blood pressure $(\mathrm{mmHg})$

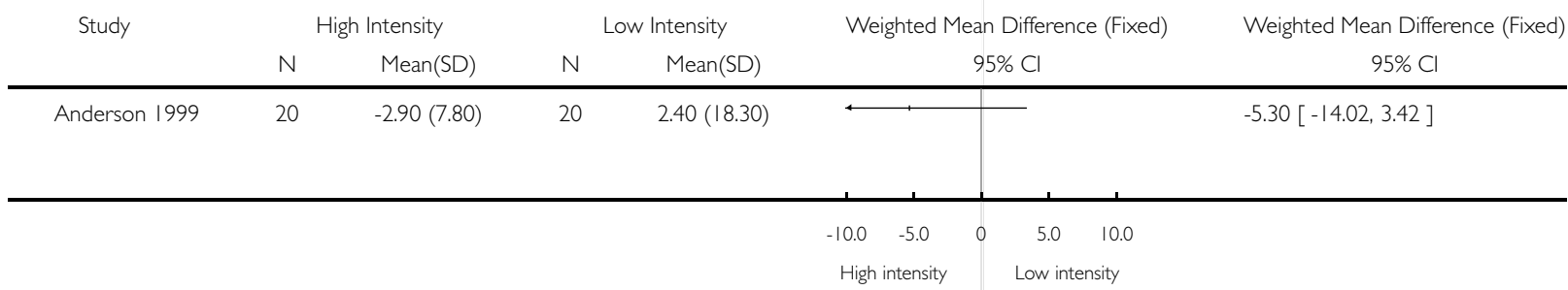

Analysis 04.05. Comparison 04 High versus low intensity exercise with dietary change, Outcome 05 Change in serum cholesterol $(\mathrm{mmol} / \mathrm{l})$

Review: Exercise for overweight or obesity

Comparison: 04 High versus low intensity exercise with dietary change

Outcome: 05 Change in serum cholesterol $(\mathrm{mmol} / \mathrm{l})$

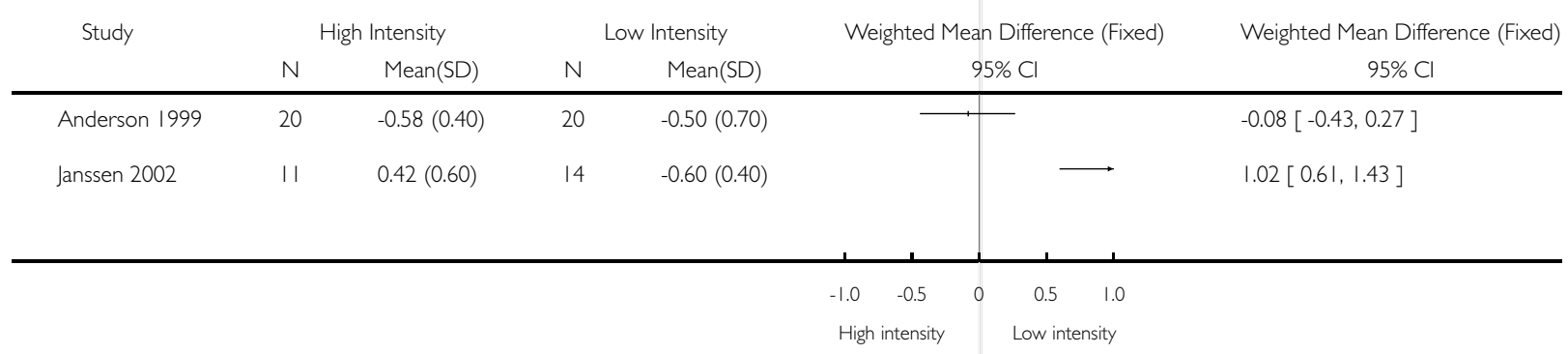


Analysis 04.06. Comparison 04 High versus low intensity exercise with dietary change, Outcome 06 Change in serum triglycerides $(\mathrm{mmol} / \mathrm{l})$

Review: Exercise for overweight or obesity

Comparison: 04 High versus low intensity exercise with dietary change

Outcome: 06 Change in serum triglycerides ( $\mathrm{mmol} / \mathrm{l})$

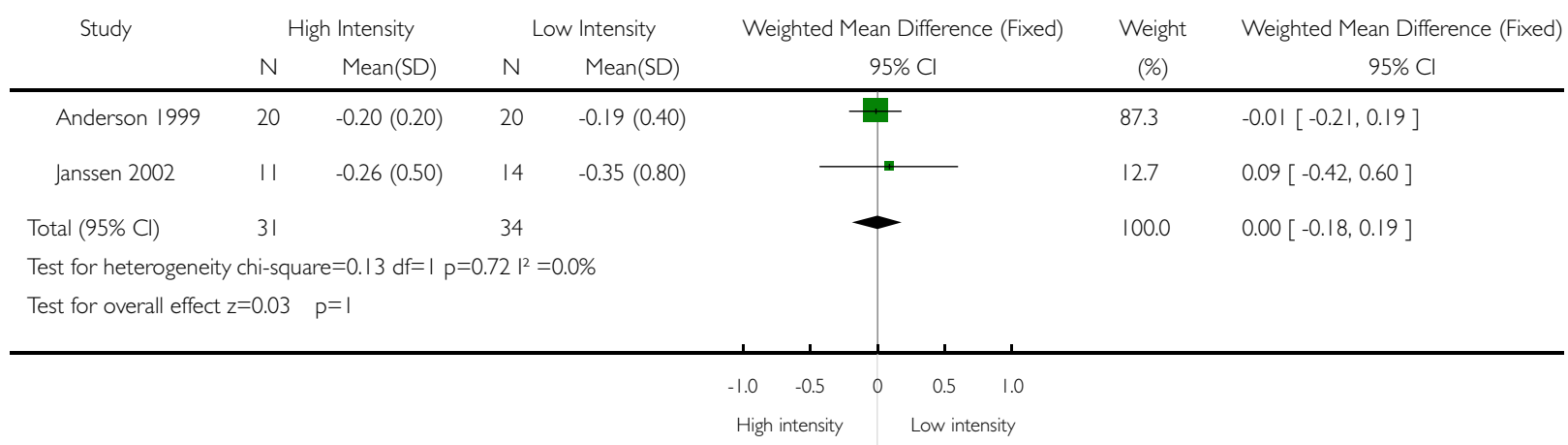

Analysis 04.07. Comparison 04 High versus low intensity exercise with dietary change, Outcome 07 Change in serum HDL $(\mathrm{mmol} / \mathrm{l})$

Review: Exercise for overweight or obesity

Comparison: 04 High versus low intensity exercise with dietary change

Outcome: 07 Change in serum $\mathrm{HDL}(\mathrm{mmol} / \mathrm{l})$

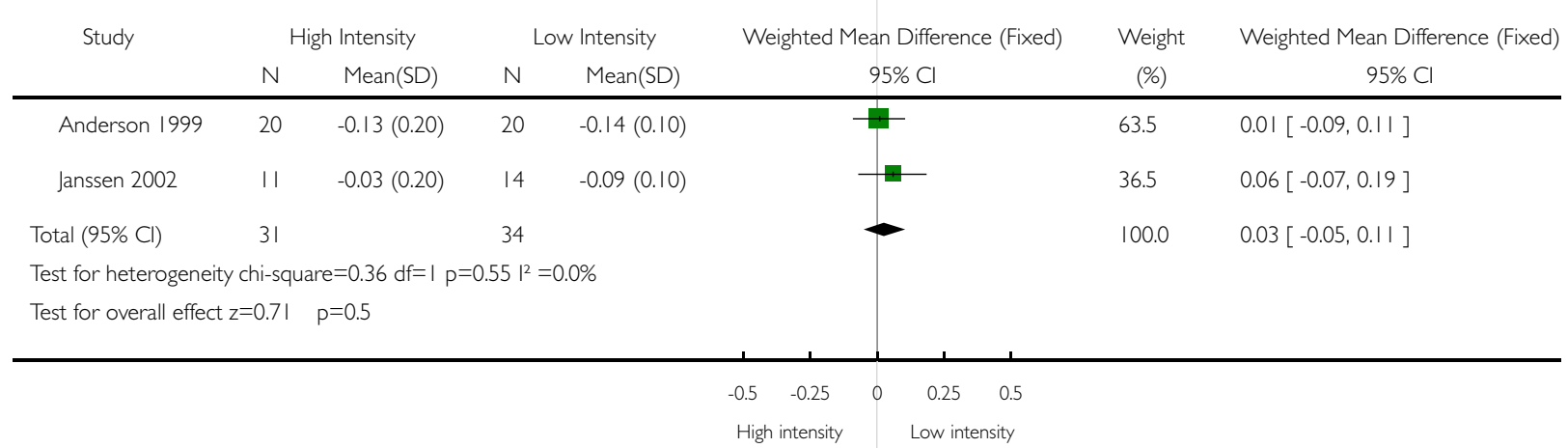


Analysis 04.08. Comparison 04 High versus low intensity exercise with dietary change, Outcome 08 Change in serum glucose $(\mathrm{mmol} / \mathrm{l})$

Review: Exercise for overweight or obesity

Comparison: 04 High versus low intensity exercise with dietary change

Outcome: 08 Change in serum glucose $(\mathrm{mmol} / \mathrm{l})$

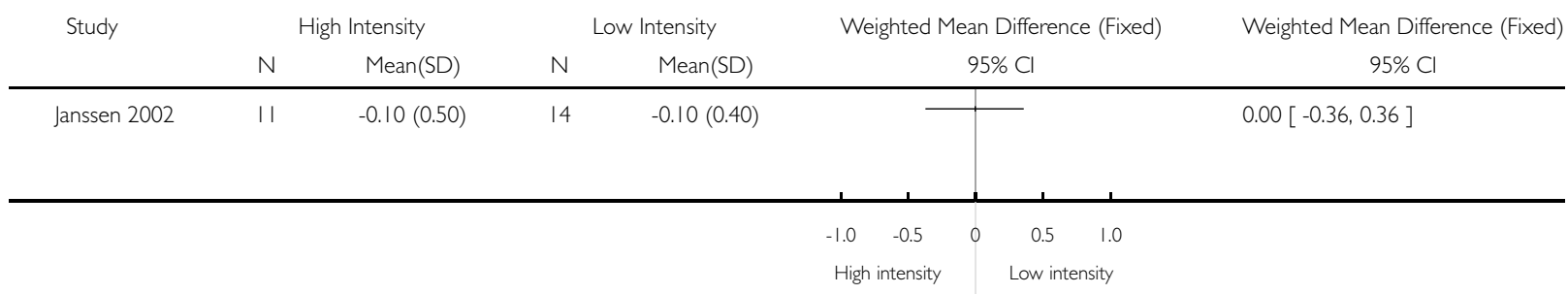

\section{Analysis 05.0I. Comparison 05 High versus low intensity exercise without dietary change, Outcome 0 I Weight change in kilograms}

Review: Exercise for overweight or obesity

Comparison: 05 High versus low intensity exercise without dietary change

Outcome: 01 Weight change in kilograms

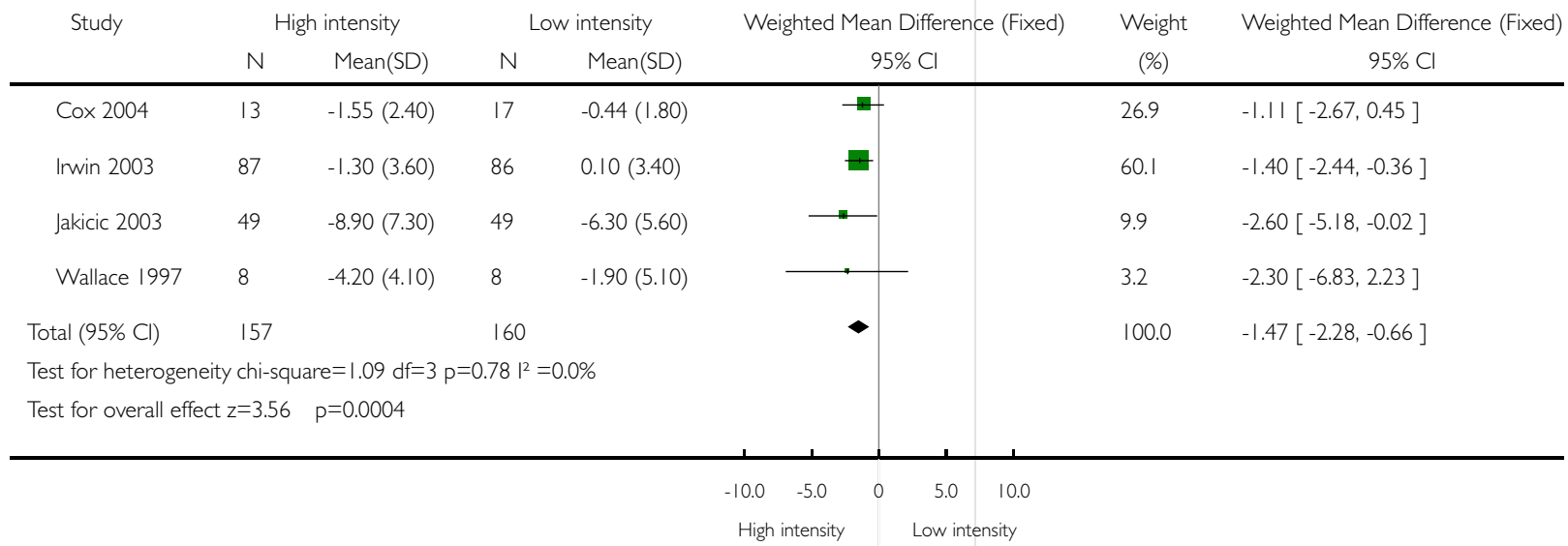

\section{Analysis 05.02. Comparison 05 High versus low intensity exercise without dietary change, Outcome 02} Change in systolic blood pressure $(\mathrm{mmHg})$

Review: Exercise for overweight or obesity

Comparison: 05 High versus low intensity exercise without dietary change

Outcome: 02 Change in systolic blood pressure $(\mathrm{mmHg})$

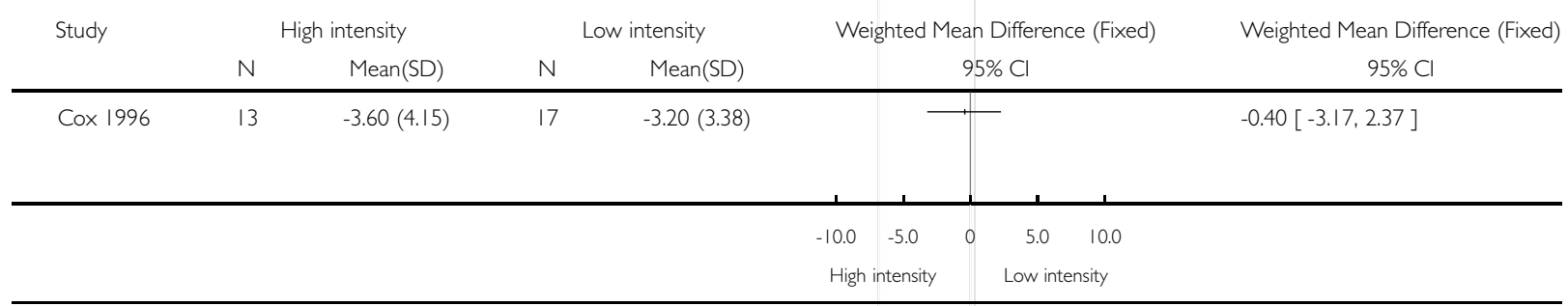

Exercise for overweight or obesity (Review) 
Analysis 05.03. Comparison 05 High versus low intensity exercise without dietary change, Outcome 03 Change in diastolic blood pressure

Review: Exercise for overweight or obesity

Comparison: 05 High versus low intensity exercise without dietary change

Outcome: 03 Change in diastolic blood pressure

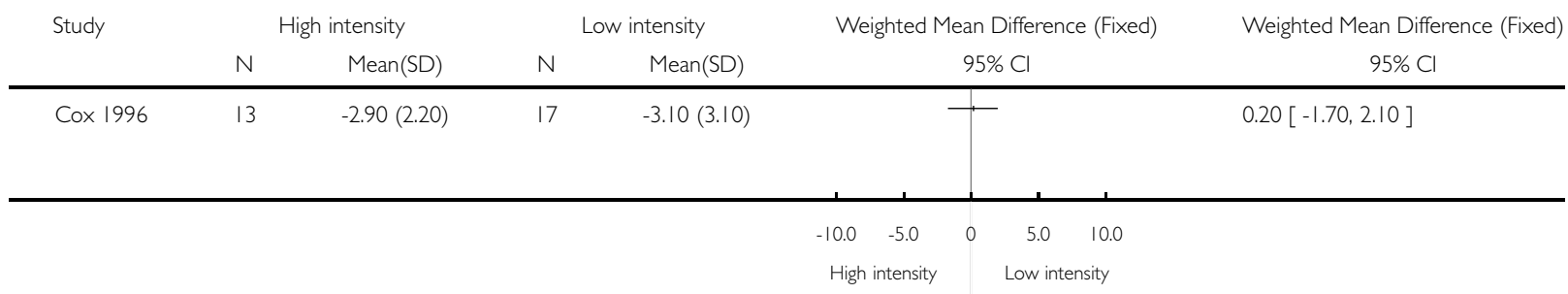

\section{Analysis 05.04. Comparison 05 High versus low intensity exercise without dietary change, Outcome 04 Change in serum triglycerides $(\mathrm{mmol} / \mathrm{l})$}

Review: Exercise for overweight or obesity

Comparison: 05 High versus low intensity exercise without dietary change

Outcome: 04 Change in serum triglycerides ( $\mathrm{mmol} / \mathrm{l})$

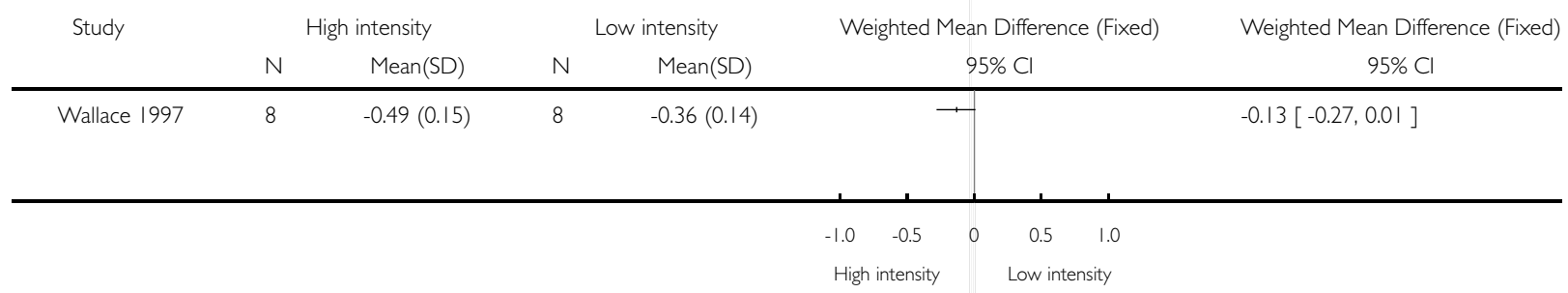

Analysis 05.05. Comparison 05 High versus low intensity exercise without dietary change, Outcome 05 Change in serum HDL ( $\mathrm{mmol} / \mathrm{l})$

Review: Exercise for overweight or obesity

Comparison: 05 High versus low intensity exercise without dietary change

Outcome: 05 Change in serum $\mathrm{HDL}(\mathrm{mmol} / \mathrm{l})$

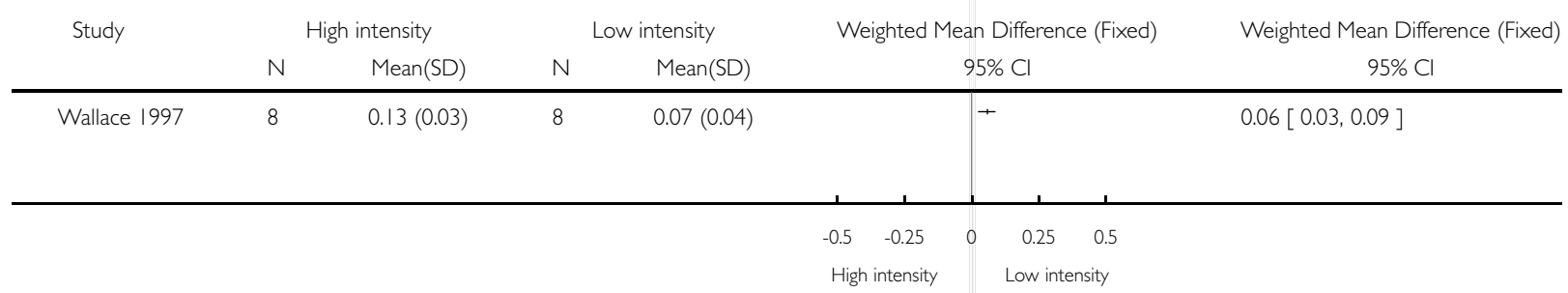


Analysis 05.06. Comparison 05 High versus low intensity exercise without dietary change, Outcome 06 Change in serum glucose $(\mathrm{mmol} / \mathrm{l})$

Review: Exercise for overweight or obesity

Comparison: 05 High versus low intensity exercise without dietary change

Outcome: 06 Change in serum glucose $(\mathrm{mmol} / \mathrm{l})$

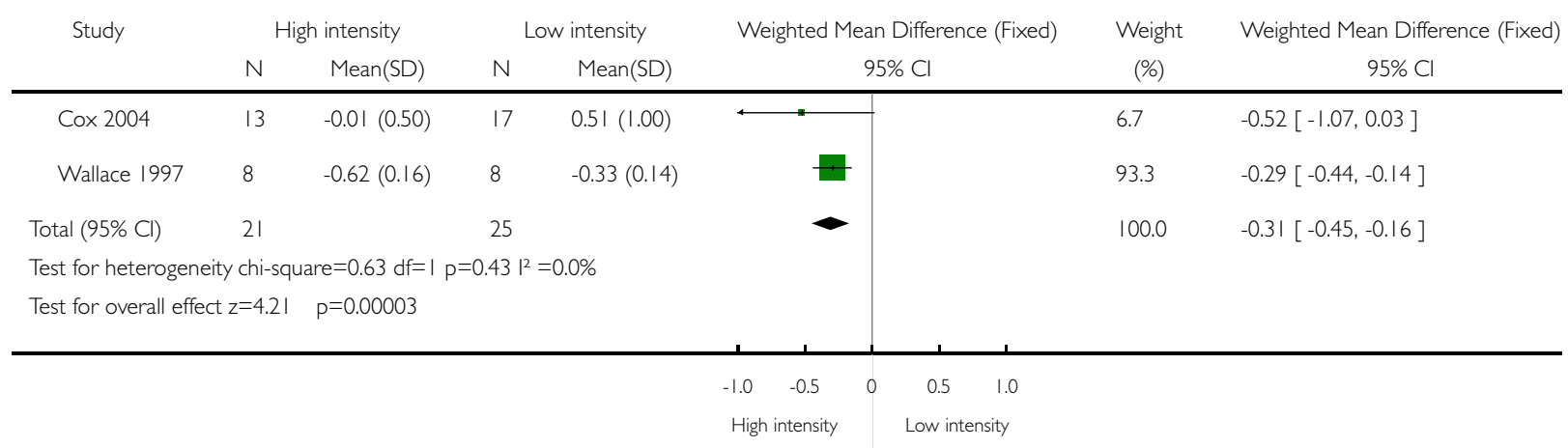

